San Jose State University

SJSU ScholarWorks

Master's Theses

Master's Theses and Graduate Research

Fall 2009

\title{
Immigrant Iranian women in search of sociopolitical and religious freedoms.
}

Khatoun Nourallahi

San Jose State University

Follow this and additional works at: https://scholarworks.sjsu.edu/etd_theses

\section{Recommended Citation}

Nourallahi, Khatoun, "Immigrant Iranian women in search of sociopolitical and religious freedoms."

(2009). Master's Theses. 3997.

DOI: https://doi.org/10.31979/etd.awgq-6bzc

https://scholarworks.sjsu.edu/etd_theses/3997

This Thesis is brought to you for free and open access by the Master's Theses and Graduate Research at SJSU ScholarWorks. It has been accepted for inclusion in Master's Theses by an authorized administrator of SJSU ScholarWorks. For more information, please contact scholarworks@sjsu.edu. 


\title{
NOTE TO USERS
}

This reproduction is the best copy available.

\author{
UMI
}



IMMIGRANT IRANIAN WOMEN IN SEARCH OF SOCIOPOLITICAL AND RELIGIOUS FREEDOMS

\author{
A Thesis \\ Presented to \\ The Faculty of the Department of History \\ San José State University \\ In Partial Fulfillment \\ of the Requirements for the Degree \\ Master of Arts
}

by

Khatoun Nourallahi

December 2009 
UMI Number: 1484353

All rights reserved

INFORMATION TO ALL USERS

The quality of this reproduction is dependent upon the quality of the copy submitted.

In the unlikely event that the author did not send a complete manuscript and there are missing pages, these will be noted. Also, if material had to be removed, a note will indicate the deletion.

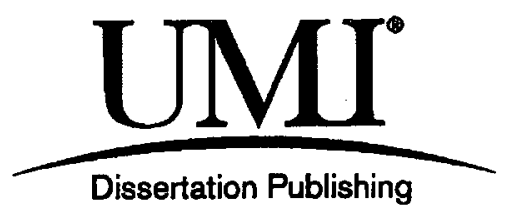

UMI 1484353

Copyright 2010 by ProQuest LLC.

All rights reserved. This edition of the work is protected against unauthorized copying under Title 17, United States Code.

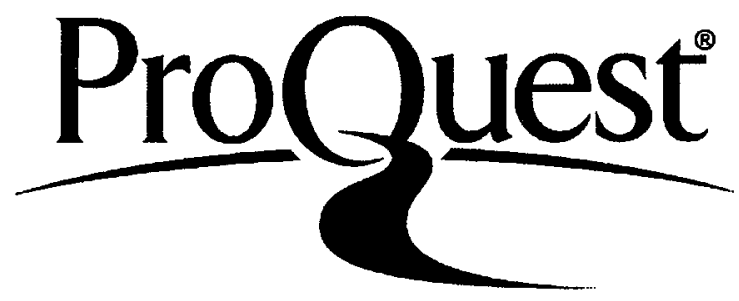

ProQuest LLC

789 East Eisenhower Parkway

P.O. Box 1346

Ann Arbor, MI 48106-1346 
(C) 2009

Khatoun Nourallahi

ALL RIGHTS RESERVED 


\section{SAN JOSÉ STATE UNIVERSITY}

The Undersigned Thesis Committee Approves the Thesis Titled IMMIGRANT IRANIAN WOMEN IN SEARCH OF SOCIOPOLITICAL AND RELIGIOUS FREEDOMS

by

Khatoun Nourallahi

APPROVED FOR THE DEPARTMENT OF HISTORY
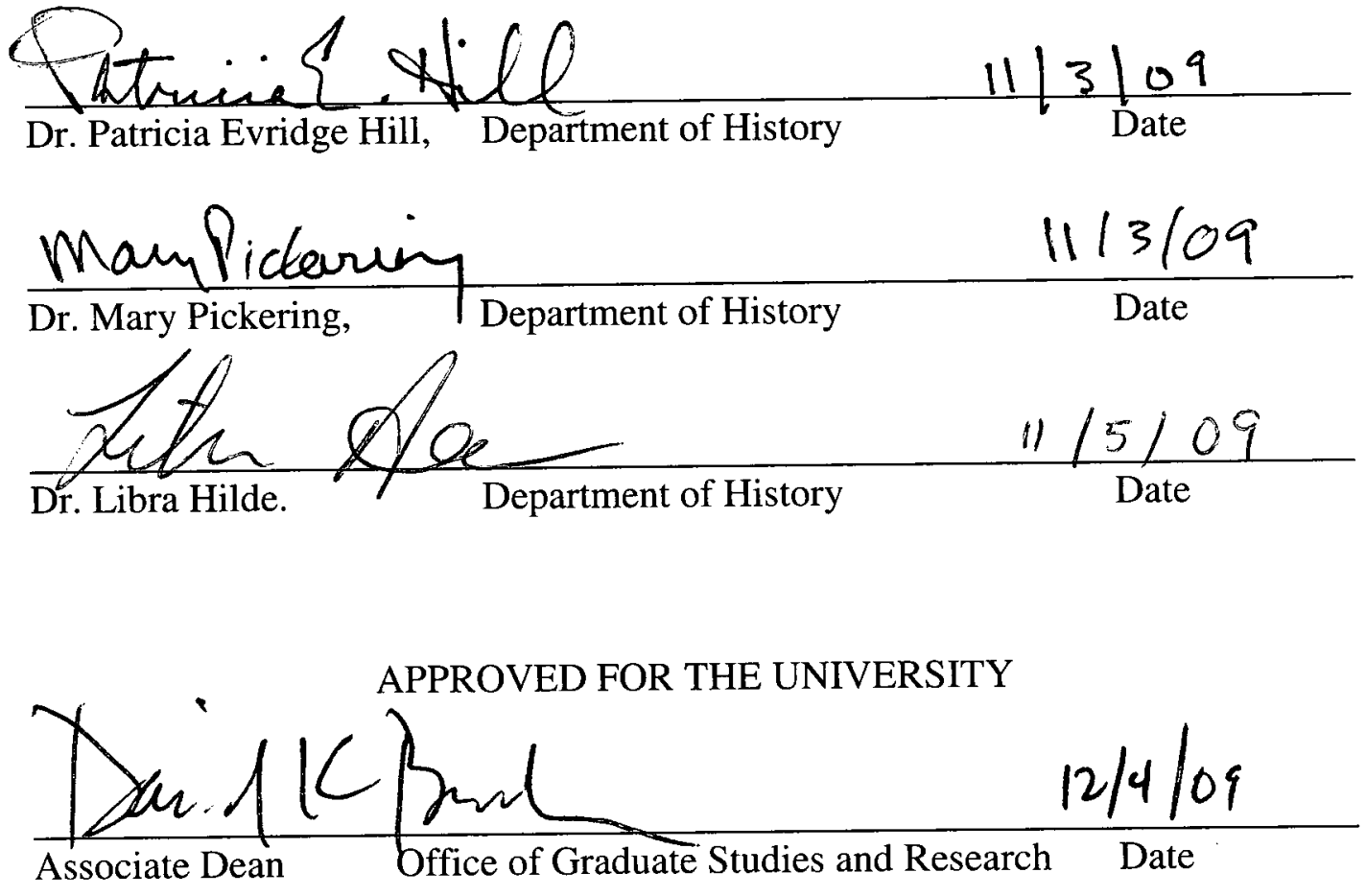


\section{ABSTRACT \\ IMMIGRANT IRANIAN WOMEN IN SEARCH OF SOCIOPOLITICAL AND RELIGIOUS FREEDOMS}

by Khatoun Nourallahi

This study focuses on the causes of migration of female immigrants from Iran to the United States over the past several decades. The purpose of this study is to determine whether the main cause of migration was the pursuit of sociopolitical and religious freedom rather than just economic opportunities.

Fifteen women were interviewed for this study who emigrated from Iran both before the 1979 Revolution and afterwards. They were questioned about the causes of their migration. Those who emigrated after the 1979 were asked specifically what role the revolution had played in their decision to migrate. They were asked whether their emigration to America had improved their economic status. The questions also focused on their consciousness of patriarchy and gender equality in Iran and in the United States.

Their responses revealed that they primarily pursued sociopolitical and religious freedoms in the United States and maintained a middle-class status after their immigration. Their decision to leave Iran was a rejection of the cultural and political patriarchy that limited their freedoms and their economic opportunities. The immigration process enhanced their awareness and quest for gender equality. Their education here, their improved socioeconomic roles, and the freedom to exercise individuality gave them confidence and power in their relationships to negotiate some of the traditional gender roles and to question patriarchy. 


\section{ACKNOWLEDGEMENTS}

I would like to begin by thanking all the participants for this study. Without their openness and desire to share their message this project would not be possible. Some of the participants had difficulties revisiting their past and recalling some painful memories. Others, despite reassurances of confidentiality, feared persecution by the government in Iran and yet continued their participation. Most of them were eager to share their stories of the injustice they had experienced, and they exercised their freedom to express their grievances as a measure of protest. I am also grateful to all three of my professors who were the readers for this thesis. Dr. Patricia Hill motivated and guided me through the past two years with much patience and encouragements; Dr. Libra Hilde instigated the idea for this study with her thought-provoking questions in class, and she motivated me to take on this project; and Dr. Mary Pickering's positive remarks and support in the past few years gave me the needed courage. I also like to acknowledge the works of the authors who provided the necessary context and background for this study. They have done the initial difficult research on this recent group of immigrants to the United States. I would also like to thank my editor Jane Cooper for her knowledge and for her losing several nights of sleep for the sake of my last-minute editing request. I am especially grateful to my husband and children who supported me with their patience and love. 


\section{CONTENTS}

Preface

Chapter I. Introduction

Chapter II. A Brief Iranian History 8

The Qajar Dynasty and the Constitutional Revolution 8

$\begin{array}{ll}\text { The Pahlavi Dynasty and Women } & 12\end{array}$

$\begin{array}{ll}\text { Reza Shah (1925-1941) } & 12\end{array}$

$\begin{array}{ll}\text { Mohammad Reza Shah (1941-1979) } & 17\end{array}$

The 1979 Revolution and Its Aftermath 23

Chapter III. Immigration $\quad 42$

$\begin{array}{lll}\text { Chapter IV. Gender } & 46\end{array}$

Chapter V. The Study 56

Methodology $\quad 56$

Pre-1979 Immigrants $\quad 59$

Post-1979 Immigrants $\quad 62$

$\begin{array}{ll}\text { Hejab } & 68\end{array}$

Discrimination against Women in the Media 73

$\begin{array}{ll}\text { Political Repression } & 76\end{array}$

$\begin{array}{lr}\text { Religious Freedom } & 80\end{array}$

$\begin{array}{lr}\text { School Discrimination } & 82\end{array}$

Discrimination in Women's Sports $\quad 83$ 
$\begin{array}{lr}\text { Cultural Patriarchy } & 85\end{array}$

$\begin{array}{ll}\text { Patriarchy in Marriage } & 86\end{array}$

Perceptions of Discrimination in Iran 91

Religious and Political Backgrounds of the Respondents 94

Immigration for Other than Economic Opportunity 95

Women's Resilience in Iran 97

$\begin{array}{ll}\text { Perceptions of the United States } & 99\end{array}$

$\begin{array}{lr}\text { Classless Society in America } & 103\end{array}$

$\begin{array}{ll}\text { Challenges of Life in the United States } & 103\end{array}$

$\begin{array}{ll}\text { Iranian Women's Activism in America } & 106\end{array}$

$\begin{array}{lll}\text { Chapter VI. Conclusion } & 113\end{array}$

$\begin{array}{ll}\text { Bibliography } & 118\end{array}$

Appendix A: Participants’ Responses 122

$\begin{array}{ll}\text { 1. Neda } & 122\end{array}$

$\begin{array}{ll}\text { 2. Mina } & 125\end{array}$

$\begin{array}{lr}\text { 3. Fari } & 127\end{array}$

4. Azar 130

5. Sharareh 136

$\begin{array}{ll}\text { 6. Sara } & 140\end{array}$

$\begin{array}{ll}\text { 7. Faranoosh } & 140\end{array}$

8. Zahra 143

$\begin{array}{ll}\text { 9. Mojghan } & 146\end{array}$ 
$\begin{array}{ll}\text { 10. Parvaneh } & 151\end{array}$

$\begin{array}{lr}\text { 11. Afsaneh } & 152\end{array}$

$\begin{array}{llr}12 & \text { Bita } & 154\end{array}$

$\begin{array}{ll}\text { 13. Azeen } & 156\end{array}$

$\begin{array}{lr}\text { 14. Faranak } & 159\end{array}$

$\begin{array}{lr}\text { 15. Sima } & 160\end{array}$

Appendix B: Interview Questions 163 


\section{PREFACE}

This study was completed prior to the Iranian presidential election of 2009, after which thousands of Iranians objected to the results, engaging in massive protests not just in Iran but across the world. They believed their basic civil right to vote for their political representative had been taken away by the religious conservative faction of the government. Its leader, Ali Khamenaie, selected the incumbent president Mahmood Ahmadinejad to be the winner of the election. Protestors went to the streets and shouted "where is my vote?" They claim to have elected Mir Hossein Mousavi (a reform-minded presidential candidate), who they believed would allow for more freedom in Iran once in office. Iranian people want democracy as they have been shouting "death to dictatorship" for weeks post-election regardless of the threat of imprisonment and physical attacks by the paramilitary guards. Women of all ages made up a significant portion of the protestors. One of these protestors was a philosophy student named Neda Agha-Soltan who was shot in the heart by the paramilitary police on June twentieth. Her death on a street in Tehran was captured on video. It was shown on televisions and computer screens around the world. She became a symbol of the struggle of Iranian women for democracy. Women have experienced many challenges under this and past regimes because of cultural and political patriarchy. They would have much to gain in demanding equality and civil rights. Iranian women's massive participation in protests since the election further confirms the findings of this study that they do long for freedom within or outside of Iran. 


\section{Chapter I.}

\section{Introduction}

In the fall of 2005, Professor Libra Hilde of San Jose State University asked students whether they believed that immigrants still came to the United States in search of freedom or whether the main objectives of immigration were to obtain economic and educational opportunities. The students responded unanimously that immigrants came here to improve their financial circumstances through work and education. The question arises, nonetheless, as to whether that response accurately reflects the reasons why Iranian women immigrants have come to the United States. Many of the politically conscious women who now reside in America have been very vocal about their experiences and their grievances not only concerning the migration process but also the circumstances of their departure from their home in Iran. One purpose of this study is to allow the Iranian women immigrants to answer the question of whether the United States still may be defined as a beacon of democracy. This research is also intended to contribute to the discourse of many Iranian women who can offer their unique experience with immigration and acculturation as well as bring attention to the injustice imposed by the Islamic Republic. The migration of Iranian women may be characterized as a form of agency, that is, as a rejection of the cultural and political patriarchy of their homeland. Women's experiences and numerous publications reveal their creativity and their efforts to become visible, showing how they have re-formed their own identities in a free society, reinvented themselves in a new environment, written themselves into history, and created a dialogue not just in the U.S. but also at an international level. 
There have been multiple new studies published about this recent group of immigrants to America, but the majority of these studies focus on psychological and social factors, in particular, as they pertain to acculturation. These studies have provided a valuable and comprehensive context for this paper. Professional historians, however, have engaged only minimally in the examination of this phenomenon, partly due to the fact that most of the women immigrated to the United States within the past thirty years. In addition, historians have been denied access to uncensored material because of restrictions from the Pahlavi (1925-1979) regime and the Islamic Republic. ${ }^{1}$ Historians, nonetheless, need to examine the socio-political aspects of Iranian women's immigration. Primary sources abound in the form of writings by Iranian women immigrants who have utilized their education to express themselves through scholarly works, poems, memoirs, art and films. These same women are remarkable for their activism in political and social organizations. Their works cover multiple aspects of women's identities as they experience gender issues at the center of political hostilities, cultural and religious values and acculturation. As Hamideh Sedghi has written, women have been placed at the center of political struggle between secular and religious forces in Iran and "control over women's identities, sexuality, and labor has been central to the consolidation of state Islamic Republic of Iran] power, both domestically and internationally.", This is especially true in the twentieth century.

\footnotetext{
${ }^{1}$ Camron Michael Amin, The Making of the Modern Iranian Woman: Gender, State Policy, and Popular Culture, 1865-1946 (Gainesville, FL: University Press of Florida, 2002), 213.

${ }^{2}$ Hamideh Sedghi, Women and Politics in Iran: Veiling, Unveiling, and Reveiling (Cambridge: Cambridge University Press, 2007), 11. This book is a comprehensive study of women's political and labor history in the twentieth century and in the beginning of the twenty-first century.
} 
Halleh Ghorashi, professor of anthropology at the University of Vrije in Amsterdam, published a study of forty Iranian women who had been politically active in Iran after the 1979 Revolution in a book entitled Ways to Survive, Battles to Win. These women became political refugees and fled to the United States and the Netherlands fearing persecution if they remained in their homeland. Ghorashi's analysis reveals that Iranian women who have immigrated to the United States have found the socio-political context of this country to provide a more favorable basis for forming roots and decisive identities in comparison to the situation of women in the Netherlands. ${ }^{3}$ The purpose of this thesis is to expand Ghorashi's study by examining the circumstances of a heterogeneous group of women who left Iran for the United States after the Revolution, to show that their migration stemmed from extensive gender oppression, political repression, and social and religious constraints, which had caused them to lose loved ones, property rights or careers. Many of these women sought educational opportunities and professional careers in the United States, but they originally migrated to America primarily to obtain socio-political and religious freedom. Educational and career opportunities arose as by-products of their migration. Professional and educational opportunities in America became available to them as the result of the crystallization of various factors, including primarily the functioning of democratic institutions and the

\footnotetext{
${ }^{3}$ Halleh Ghorashi, Ways to Survive, Battles to Win: Iranian Women Exiles in the Netherlands and the United States (New York: Nova Science Publisher, 2003), 3-24.
} 
capitalistic system, which allow for an open market, more equal opportunities and a comparatively open society. ${ }^{4}$

Slow economic growth in Iran has been a feature of the post-revolutionary regime. As the result of interference in the economy of the country, women have been pushed out of the work force and into households where they are dominated by the patriarchy even in the domestic arena. ${ }^{5}$ The present study shows how gender has become a battle ground for modernism, fundamentalism, cultural values and religion and that Iranian women immigrants have confronted the challenges of relocation in order to determine their own destiny and identities.

A short summary of Iranian history will be presented at the outset of this paper to demonstrate how modernism was promoted in the past, enhancing the political consciousness of Iranian women to resist oppression by several regimes in Iran. This, indeed, motivated their migration in search of freedom. This thesis thus discusses the causes for migration as well as the socioeconomic status of these women and their religious practices both pre- and post-migration. In order to determine how gender has influenced the process of immigration, one must deconstruct the perceptions of these women as they have related their experiences in America. It is necessary to evaluate the relative weight of their native cultural values versus American values as they have influenced their decision to remain in the United States and to assimilate to various degrees. Oral interviews and written surveys of a diverse group of fifteen Iranian women

\footnotetext{
${ }^{4}$ Elhum Hagighat, "A Comparative Analysis of Neopatriarchy and Female Labor Force Participation in Islamic Countries," Electronic Journal of Sociology 7, no. 1 (2005), 2-7, http://www.sociology.org. http://www.sociology.org/archives.html.

${ }^{5}$ Sedghi, 9-11.
} 
in Northern California from various educational and class backgrounds provide the data. This study contributes to the migration literature of a community marked by ongoing hostilities and lack of dialogue at the international level between Iran and the United States and will increase understanding and compassion between the two peoples.

Implicit in the argument that Iranian women have fled Iran for political and social freedoms lies the suggestion that they have a political consciousness; they were keenly aware of the lack of many civil and legal freedoms and hoped to find them abroad. Consciousness shapes and is shaped by migration, according to Mahasti Hashemi. Hashemi quotes Patricia Zamudio, who defines consciousness as "people's awareness of resources (potential or immediately available to them) and their knowledge of the way to use them under particular political-economic conditions." Citing Gramsci, Marx and Roseberry, Zamudio writes that "to comprehend the underlying process by which consciousness emerges, it is important to state that ... people's awareness does not arise spontaneous or mechanically in front of material conditions; a person's history, as it is carried on in practices and experiences, constructs such awareness."7 Finally, Zamudio quotes Belinda Bozzoli for the proposition that "how and when [consciousness] is formed is seen as a process, located within time and place, and material reality." 8

\footnotetext{
${ }^{6}$ Patricia Zamudio, "Huejuquillense immigrants in Chicago: Culture, Gender, and Community in the Shaping of Consciousness" (Ph.D. diss., Northwestern University, 1999), 13-14, quoted in Mahasti Hashemi, "Immigrants and Exiles: Iranian Women in the United States" (Ph.D. diss., Rutgers, the State University of New Jersey-New Brunswick, 2006), 261.

${ }^{7}$ Ibid.

${ }^{8}$ Belinda Bozzoli, Women of Phokeng: Consciousness, Life Strategy, and Migrancy in South Africa, 1900-1983 (Portsmouth, NH: Heineman, 1991), 240, in Zamudio, 13-14.
} 
A review of modern Iranian history not only helps to contextualize the discussion but also reveals that numerous social and political events have transmitted to Iranian women an awareness of their rights as well as opportunities for political activism. Their political consciousness and activism may be traced back to the Iranian Constitutional Revolution of $1906 .^{9}$ The Revolution was a remarkable democratic achievement, a grassroots social, political, and cultural movement in which numerous women actively participated. ${ }^{10}$ A democratic and nationalistic agenda lay at the heart of the revolution. The Iranian people demanded greater political representation, restrictions on the authority of the monarch, and a curtailment of the economic concessions that the monarch was making to the great powers of Great Britain and Russia. The Iranian economy with its raw material had become a supporting economy for these two powers. As women participated in the nationalist efforts and fought against the domination of imperialistic powers, they became increasingly aware of their own domination by the patriarchy, which they experienced on a daily basis. Only a small group of the elite and middle-class women became politically active, but a larger group of women were exposed to the concepts of democracy and independence. ${ }^{11}$ The modernization and secularization efforts of the Pahlavi Dynasty (1925-1979) further provided women with the awareness of gender inequality and stimulated activism directed specifically towards effectuating gender equality. Camron Amin credits the Women's Awakening of 1936-41 as a crucial project and an opportunity that triggered the feminist push for progress and public

\footnotetext{
${ }^{9}$ Sedghi, 12 .

${ }^{10}$ Janet Afary, The Iranian Constitutional Revolution, 1906-1911: Grassroots Democracy, Social Democracy, and the Origin of Feminism (New York: Columbia University Press, 1996), 3-12.

${ }^{11}$ Ibid.
} 
demand for gender equality. ${ }^{12}$ Active participation in the overthrow of the Shah's regime in 1979 energized and further politicized Iranian women. ${ }^{13}$ The mandatory hejab and sex segregation by the current regime also increased women's gender consciousness. The Iran-Iraq war then helped politicize women as they participated in community activities to provide medical help and produce food. ${ }^{14}$ Overall the war with Iraq provided an opportunity for women to enter the work force. ${ }^{15}$

The fact that Iran unlike other Middle Eastern countries has never been fully colonized, has given its people a great sense of independence and a stronger drive for social and political activism. ${ }^{16}$ Iranian women's history reveals years of activism and resistance not only for nationalist causes but also against the patriarchy embedded in the legal and social systems. The argument presented here is that women's migration to the United States represents only one more example of their continual fight and search for democracy and gender equality.

\footnotetext{
${ }^{12}$ Amin, 25.

${ }^{13}$ Ghorashi, 60-70.

${ }^{14}$ Elaheh Rostami Povey, "Feminist Contestations of Institutional Domains in Iran," Feminist Review no. 69 (Winter, 2001): 47.

${ }^{15}$ Valentine M. Moghadam, "Islamic Feminism and its Discontents: Toward a Resolution of the Debate," Signs 27, no. 4 (Summer, 2002): 1138.

${ }^{16}$ Afary, 15-25. Countries such as Russia, England and Turkey have had spheres of influence in Iran, but competition among these powers at the time when the United States entered the arena, plus the resistance of the Iranian people, prevented Iran from being more than a semi-colony.
} 


\section{Chapter II.}

\section{A Brief History}

\section{The Qajar Dynasty and the Constitutional Revolution}

The Constitutional Revolution of 1906 challenged the Qajar Dynasty (17961925). Afary explains that numerous women during this era participated in political power at a grass-roots level and that the "seeds of feminism were firmly planted." traces the progressive efforts of women in the 1979 Revolution back to the early women's movement during the 1906 Revolution. She defines the 1906 Revolution as a multicultural and multi-ideological democratic and modernizing achievement with the establishment of a parliament and with grass-roots councils taking part in democratic activities. Women played a significant role in defining the political direction of the revolution as they addressed gender inequalities, women's emancipation, and a call for modernization through legal and social reforms. One important reason for women's involvement in political reforms during this time was that, at the beginning of the twentieth century, women's sexuality became a central issue of control between the rival political and religious groups as a means for each to legitimize its power. ${ }^{18}$ Amin confirms this argument in reference to Reza Shah. ${ }^{19}$

By 1906, many Iranian women had become disgruntled. They were nationalistic and anti-colonialist, directing their anger specifically against Russia and England who

\footnotetext{
${ }^{17}$ Ibid., 177-78.

${ }^{18}$ Ibid., 2-15. The Revolution was initially successful due to the coalition of groups: religious clerics opposed the central authority of the Shah; many merchants objected to increased tariffs; liberals and radical intellectuals, including many women, demanded education reforms and reform of the family laws.

${ }_{19}$ Amin, 63.
} 
were competing over the political and commercial markets of Iran. Women demanded a constitutional government to replace the monarchial power of the Qajar who had allowed Iran to become a semi-colony of Russia and England. Many elite women demanded education, enfranchisement and the abandonment of the veil. ${ }^{20}$ The dominant religion was Shi'i and the Quran was interpreted by men who had much influence over politics of the state. The economy was underdeveloped, and the leaders neither recognized nor greatly valued women's work in the house and in the marketplace. Under inheritance laws, daughters received only one-half the amount that their brothers received from the father's estate, while the widowed mother received only one-eighth of the amount that the son received. Women, regardless of their class and culture, were confined to the home and family. Veiling and polygamy were practiced legally; although they had also been practiced before the coming of Islam to Iran in the seventh century, they had long since been maintained by interpretation of the Quran. ${ }^{21}$

Women played a significant role in the 1906 Revolution with their active engagement in protests to demand a constitutional government and a representative parliament. They provided moral and financial support to the constitutionalists. They participated in a plan for a national bank, facilitated strikes, boycotted foreign textiles and services, and formed human barriers to protect the anti-government activists under attack. They also wrote letters and petitions to the parliament requesting education for women. Middle-class and elite women, such as Yahya Dawlatabadi (1881-1961), were among the

\footnotetext{
${ }^{20}$ Sedghi, 44. "The British needed Iran to maintain their Indian empire and to secure markets for their exports, while the Russians were interested in annexation and political and commercial domination." Ibid., 40. Sedghi's book is the most recent and comprehensive study of modern women's history in Iran. ${ }^{21}$ Ibid., 25-40.
} 
main participants. She was a member of the Anjuman [Council] for Freedom of Women, which opened the first girls' schools in the city of Isfahan and published a weekly journal, Women's Voice, the first paper to call for abandonment of the veil. Other journals were published as well: Danish [Knowledge] 1907, Shokoufeh [Blossom],

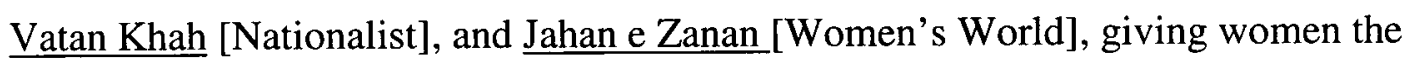
opportunity to express demands for reforms in education, family laws, and unveiling, as well as the right to greater participation in politics and society. Shokufeh specifically discussed gender equality, fair treatment of women by their husbands, and the danger of early marriages. $^{22}$ Women also formed numerous other anjumans including The Freedom of Women Council of 1907 and the Council of Ladies of Iran, which helped raise funds for schools, hospitals, and orphanages. Their demands went beyond women's rights to promote the welfare of the poor, extended to the distribution of bread as well as the reform of a judicial system that would reach into the provinces and end the autocracy and cruelty practiced there. ${ }^{23}$ Women such as Sadigah Dawlatabadi, Muhtaram Iskandari, and Shams al-Muluk Javahir Kalam continued their activism throughout the 1920s and 1930s as advocates of women's rights. They did achieve certain social reforms such as mass education and paid employment for women.

Other women formed councils that established and financed cultural and social institutions such as girls' schools, health clinics, theaters, and orphanages. They did so against the opposition of some religious conservative leaders who considered the girls' schools as anti-Islamic. They also went against the will of their relatives, who at times

\footnotetext{
${ }^{22}$ Sedghi, 55; Afary, 178-208; Amin, 40, 57, 59.

${ }^{23}$ Afary, 192.
} 
threatened these educational or political activities. They had to challenge not only legal but also cultural patriarchy. ${ }^{24}$ These women opposed child marriage, polygamy, and easily male-instigated divorces. They also pushed for women's suffrage. They became teachers, speakers on political issues, and newspaper writers, and they established women's clubs. Their determination to obtain legal and social reforms strengthened, as they were exposed to international movements, such as socialism in Russia, and they were influenced by the writings of European intellectuals. The Iranian women compared themselves to the European women who were receiving an education and were inspired by the simultaneous women's movements in the United States, Turkey, Egypt, Japan, China and England. ${ }^{25}$ Iranian women's groups openly appealed to the British suffragists to support their efforts to put pressure on the British government to give Iran a chance for greater independence.

The reform movement which emanated from Constitutional Revolution of 1906 was impeded by the outbreak of the World War I as Iran became a sphere of influence for Britain, Russia and Turkey. The Parliament suspended its work until 1921, and women failed to get the right to vote. Women, however, had acquired political awareness through their efforts for nationalism and independence, and their activism had empowered them to continue fighting for education and family-law reforms through a dialogue in their journals that continued from 1907 through the $1920 \mathrm{~s}^{26}$

\footnotetext{
${ }^{24}$ Ibid., 11, 189-90.

${ }^{25}$ Sedghi, 76; Afary, 200.

${ }^{26}$ Sedghi, 150; Afary, 120.
} 


\section{The Pahlavi Dynasty and Women}

\section{Reza Shah (1925-1941)}

Reza Khan and later his son, Mohammed Reza, were the only two monarchs in the Pahlavi dynasty, which succeeded the defunct Qajar dynasty in 1925. The Pahlavi dynasty sought to establish a centralized, capitalist and modernized government, modeled after a secular, Western-style regime. They tried to accomplish this task very rapidly, without also adopting democratic measures, such as rule through the consensus of the majority. The Pahlavi dynasty failed to evaluate the willingness or readiness of the Iranian society to accept drastic social and legal changes. Reza Shah set out to transform Iran by separating the state from religion. He overlooked the strongly imbedded traditional and religious beliefs of the Muslim majority and so overruled the authority of the clerics. Clerics had exercised much influence and power over the majority in fixing moral rules, especially as they pertained to women's lives and behavior. The clerics determined the rules governing gender relations, such as marriage, polygamy, and divorce, through the interpretations of the Quran. ${ }^{27}$

Reza Shah reformed the education system by removing the schools from the authority of the clerics. He secularized the curricula by introducing a more scientific and French model, even for women. He professionalized teaching and established schools for girls and women to give them the opportunity to obtain higher education. ${ }^{28}$ Although some legal measures had been taken to improve women's educational opportunity, many traditional people had yet to accept the idea of educated women. Many women, however,

\footnotetext{
${ }^{27}$ Sedghi, 66; Amin, 74.

${ }^{28}$ Sedghi, 70 .
} 
did take advantage of their new opportunity and fought to maintain the chance to receive an even more secular education. They even tolerated occasional harassment, for they had to fight the verbal and physical attacks of men and women who feared that women's education would undermine the patriarchal family. ${ }^{29}$

The lack of tolerance from the majority, and the heavy influence of Shari'eh [Islamic law] on some of the legal reforms under consideration resulted in slow and slight reforms. An example of this is the 1925 Penal Code, which addressed adultery. The code continued to put control of women's sexuality into the hands of the men, stating that if a man saw his wife in the act of adultery, he would be exempt from any punishment for killing her and her accomplice. If he killed his sister or daughter in such circumstances, he would receive only six months imprisonment. If a husband, however, committed an act of adultery, he would be given only a short prison sentence. ${ }^{30}$ Other reforms in 1935 included a law under which the marriage age for women increased from nine years to fifteen, while for men the age went from fifteen years to eighteen. A marriage license was required, however, from a civil bureau, as opposed to the religious court, and this switch removed authority for granting marriages and divorces from the clerics. Women also acquired the right to own property, and their husbands now had the responsibility to provide food, clothing and shelter for them. Women were active participants in bringing about these changes. They demanded, in particular, reforms in marital and divorce laws,

\footnotetext{
${ }^{29}$ Ibid., 72.

${ }^{30}$ Ibid., 75.
} 
the right to vote, citizenship, unveiling, and education through public discussion of these issues in their journals and their organizations. ${ }^{31}$

Reza Shah tried to implement the same system of Westernization as that of Mostafa Kemal Attaturk in Turkey. He had a vision of modernizing the economy through industrialization and the building of new infrastructure such as roads, railways and telephone lines. He also built up a strong and modern army with uniforms and powerful armaments and he modernized the bureaucracy and the judicial system. Oil production and revenues increased as he employed Western science and technology to achieve his economic goals. Oil revenue, the increase of income taxes from the ever growing working class, and the capital from foreign trade all contributed to further industrialization and therefore to urbanization and economic development.

Women increasingly became a legitimate part of the work force as they began working in spinning and weaving plants as well as in the service sector. Their secular education also helped them to secure higher employment throughout the 1950s, especially as a larger labor force became necessary to accomplish the goals of modernization and economic expansion. ${ }^{32}$

On the cultural level, Reza Shah set out to portray a progressive image of Iranians by trying to westernize music and men and women's clothing. He went so far as to enforce the unveiling of women in 1936. He and a group of social democrats equated modernity and enlightenment with unveiling. Women were encouraged to wear European clothes and be educated to work as part of the labor force outside their homes.

${ }^{31}$ Sedghi, 75-78.

${ }^{32}$ Amin, 57; Hashemi, 7; Sedghi, 80-85. 
Sedghi and Amin argue that while Reza Shah, a very patriarchal monarch, portrayed Iranian women as being liberated, he was, in fact, exploiting them to legitimize his state as secular and modern in order to gain national and international approval. His determination to emulate the European state system entailed the rejection of all forms of opposition to his regime, secular and religious. Although he did reform some of the family laws to benefit women's rights and began gradually to bring women into public spaces, these changes fell far short of women's expectations for gender equality. Furthermore, it was too much to assume that unveiling alone could suggest gender equality, modernization, or Westernization for that matter. Many women felt obliged or ordered to unveil, again deprived of the chance to express themselves and of the freedom to practice Islam in the way they wished. Sedghi argues that it constituted a transfer of power over women's sexuality from the clerics to the state. ${ }^{33}$ In the 1930s Reza Shah shut down all independent women's organizations, which were led by activists from the Constitutional Revolution, in favor of setting up a state-sponsored Kanun-e Banovan [Ladies Center] that was mainly composed of elite women.

In general, younger urban women, especially schoolgirls, welcomed the freedom to wear sporty European clothes. But Iranian society as a whole saw women's roles almost entirely in terms of their being mothers and wives. ${ }^{34}$ Women were the honor of the nation. Their chastity determined the respect paid to their husbands and families in the community. Women were not allowed to participate in politics. They used creative

\footnotetext{
${ }^{33}$ Sedghi, 61, 89, 277; Amin, 49, 58-79.

${ }^{34}$ Nahid Yeganeh, "Women, Nationalism and Islam in Contemporary Political Discourse in Iran," Feminist Review 44 (Summer 1993): 4.
} 
ways nonetheless, to push further to take advantage of new educational opportunities, even though it still had to take place within the confines of the domestic sphere. They argued that education would make them better mothers and wives. They wrote letters to the members of the parliament, arguing that secular education for women would be economically beneficial in helping some women avoid prostitution or begging. Afary characterizes this effort as a form of feminism that has been practiced for centuries in non-Western societies. ${ }^{35}$

Iranian history and the efforts at modernization have provided many opportunities for women to become politically conscious and active. The history of the women's movement in Iran reveals a consistent struggle for freedom and equality. In 1941, Allied forces occupied Iran to protect the oil installations from falling into the hands of Germany since Reza Shah had allied with the Nazis during World War II. The Allies deported the Shah to South Africa in 1941, and he died there in 1944. His son Mohammad Reza, who was only twenty-two years old at the time, then occupied the throne until the 1979 Revolution. There was diversity in the activism of women as they encountered leftist and Islamic ideologies and western politics. The Soviet Union tried to turn the two northern states of Iran, Azarbaijan and Kurdistan, into communist states so that they would become separated from Iran and become part of the Soviet Union's sphere of influence. On the other hand, the Islamic agenda and the efforts of the clerics to return to power were intense. Meanwhile, the United States was trying to incorporate

\footnotetext{
${ }^{35}$ Afary, 10, 191.
} 
Iran into its own orbit of influence. Thus the major political forces of the time in Iran consisted of communism, Islam, and nationalism. ${ }^{36}$

\section{Mohammad Reza Shah (1925-1979)}

Mohammad Reza Shah followed in his father's footsteps as he instigated a reform program in 1963 entitled the White Revolution, which consisted of a set of social and economic reforms to strengthen the Iranian economy. It included land reform, nationalization of forestland, sale of state-owned industries, and profit-sharing in industry. He also instituted the enfranchisement of women leading to their getting the vote in 1963. In addition, he established an educational corps for literacy programs in villages. ${ }^{37}$ His goal was to stimulate economic growth through foreign and domestic investment and to develop projects in rural and urban areas. He was successful in doing so, and the GNP increased year after year. ${ }^{38}$ With economic development came a larger labor market and the need for women to enter the workforce outside their homes, mostly in the service sector. If some women did not personally experience working outside their homes, at least, they were exposed to numerous women who did experience various degrees of financial and social freedom and power as their contribution to the family income increased. The same was true with regard to the unveiling practiced by some women. Although the government and some intellectuals often portrayed unveiling to mean progress and modernization, only a small group of women gained the social

\footnotetext{
${ }^{36}$ Sedghi, 92-93.

${ }^{37}$ Ibid., 104.

${ }^{38}$ Ibid., 105.
} 
freedom from unveiling and having to wear Western clothing. ${ }^{39}$ These women were mostly in the larger cities with a new economic environment, and the new practice was especially popular among the new younger generation. Nonetheless, their example provided the opportunity for many other women to witness and become aware of the possibilities of such freedoms. Women's employment during the 1960s and 1970s grew, especially with the encouragement of the Shah as he facilitated access to part-time work for many women to allow them to maintain their housework. Working more also translated into consuming more. Women became the main consumers, abandoning traditional methods of housework for modern appliances and processed foods and other ready-made household products. Some hired maids to do their housework while others put their children in nurseries. As they produced a greater share of family income, women moved further away from traditional roles. ${ }^{40}$ With the growing demand for women workers and availability of education for a broader group of women, women took advantage of these opportunities in the 1960s and 1970s so that by 1977 one out of every ten rural women and five out of every ten urban women were now literate, as more educational institutions accepted women. ${ }^{41}$ In January of 1963, women earned the right to vote and the Family Protection Law of 1967 gave women greater legal rights in such areas as the custody of their children, the right to divorce, the right to collect alimony, and access to higher education and work.

\footnotetext{
${ }^{39}$ Ibid., 104-05; Amin, 78.

${ }^{40}$ Ibid., 111.

${ }^{41}$ Sedghi, 121-22; Hashemi, 7.
} 
The Family Protection Law addressed age restrictions for marriage, divorce, child custody and polygamy. Women obtained the right to submit their own divorce petitions, and men no longer could divorce them at will but had to present valid reasons for petitioning. This law required that such petitions for divorce be adjudged in the Family Protection Courts and not by Islamic jurists. The couples, however, were encouraged to reconcile under the Islamic agenda, which promoted family unity. ${ }^{42}$ In reference to child custody, the mother became the legal guardian of her children in the event of her husband's death instead of the father's relatives as had been the case previously. The practice of polygamy was discouraged by the legislation, and the revision of the Family Protection Law in 1975 further empowered the first wife by requiring her consent for additional marriages. As a response to the population increase of the 1960 s, the government and some voluntary organizations offered modern forms of contraceptives and set up family planning clinics. When this was not enough to curb the population increase, the state legalized abortion in 1973. Sedghi argues that all these new legal rights benefited mostly upper class women, with the exception of the new divorce laws. The punishment for adultery remained the same as in 1940. It was the state's concession to religious authorities. ${ }^{43}$ All of this, nonetheless, contributed to diminishing the power of patriarchy. ${ }^{44}$ Much more reform, however, would have to be inaugurated at the social and legal level to progress toward true gender equality. ${ }^{45}$ Women's suffrage was met

\footnotetext{
${ }^{42}$ Nahid Yeganeh,"Women, Nationalism and Islam in Contemporary Political Discourse in Iran" no. 44 (Summer 1993): 4.

${ }^{43}$ Sedghi, 137-43.

${ }^{44}$ Ibid., 133.

${ }^{45}$ Ibid., 27.
} 
with immediate opposition by clerics, such as Khomeini, who believed it to be unconstitutional and harmful to Islam. The tension over power and authority between the state and the clergy was on the rise again. ${ }^{46}$ The Labor Law of 1958 stated that women should receive equal pay for work equal to that of men. Little effort was made to implement this law, however, as employers justified paying women less on the grounds of their not being the head of the family. This is yet another sign of cultural patriarchy that women had to fight on this second battleground beyond the formalities of the legal or state patriarchy. Despite the Labor Law requiring the minimum age of workers to be twelve, many female carpet weavers were around nine or ten years old. Women were discouraged by the Labor Law to work the night shift or perform "difficult" and "harmful" work while these often higher-paying positions were given to men. The perception of women as family keepers, rather than the head of the family, and as frail did much to limit their advancement legally, economically and socially. ${ }^{47}$

The Mohammad Reza Shah Pahlavi regime, 1941-79, however, did not allow women to have independent political activities. Women's discontent grew as they experienced legal but not social freedom, discrimination and sexual harassment at work, inequalities in the distribution of wealth, lack of infrastructure and health care, and the imperialism of the West. In the 1970 s for the first time, incarcerated Iranian women could be identified as political prisoners, for they might receive life sentences or be executed for their activism. ${ }^{48}$

\footnotetext{
${ }^{46}$ Ibid., 134-155.

${ }^{47}$ Ibid., 147-49.

${ }^{48}$ Ghorashi, 53-59.
} 
Prior to the Revolution, upper-middle class women were the main political participants, active through political organizations or as writers, but as social, intellectual and political movements spread, so did the massive participation by women in lower socioeconomic classes during and after the revolution. One of the reasons that Islamic leaders, including Ayatollah Khomeini, inspired the involvement of women of all classes in the revolution lies in the slogans they promulgated about Islam protecting women against objectification and the corruption of the Western culture. Khomeini, however, objected to the legal gains of women in the family courts and viewed their voting rights as being too Western. This reveals that gender was definitely part of the revolutionary discourse. Women had an important role in the revolution with their participation in spreading the revolutionary literature and news. They did so even through religious ceremonies such as rowzeh and sofreh, as well as by helping the wounded and the endangered by providing food, nursing and shelter ${ }^{49}$

Women did not remain passive in the face of legislative changes or legislations. Their response varied based on class, education and background. Sedghi divides women into two groups. The conformists mostly consisted of the upper and elite women, and the nonconformists predominantly came from the middle and lower classes. The conformists worked through and with state feminism as they pushed for stronger family and civil rights. Their primary goal, however, was the state's advancement and interest. The Women Organization of Iran or WOI (1970-79) was formed by a group of conformist

\footnotetext{
${ }^{49}$ Ibid., 60-61. "Both rowzeh and sofreh are religious gatherings organized by women. Rowzeh is a religious gathering in which a male or female religious figure recites the tragedy of karbala. Sofreh is a religious ceremony to give thanks for a wish having come true." Ibid., 61 .
} 
women and led by Mahnaz Afkhami as its Secretary General. The Shah eliminated independent or dissident female organizations. The WOI supported the Shah and promoted the state's agenda. Its six main interests were women's welfare, legal reforms, publications, social concerns, international affairs, and organizational necessities. It set out to raise consciousness of the subordination of women and inspire women to participate in the political process. The WOI lobbied for the right of women to have abortions with their husband's consent and in the case of an unmarried woman up to the eighth week of pregnancy. It also supported and pushed for the formulation of the Family Protection Law. ${ }^{50}$

Elaheh Povey argues the existence of these legal rights did not fully translate into cultural or social acceptance of these laws; rather the persistence of social patriarchy in many instances did not allow the majority of working-class women and religious middleclass women to take advantage of these reforms. Many of these women were alienated by the state's process of modernization of many institutions. ${ }^{51}$ These nonconformist women, who came mainly from the middle and lower classes, opposed the state's oppression through various forms of resistance, sometimes through poetry and songs. Many of them experienced imprisonment and torture for expressing their political, ideological and religious opposition to the regime. Some of these women had received an education and experienced employment outside their homes, so their resistance to the regime became more radical through the 1970s. Their approach was not monolithic. Rather they protested independently and in groups or in large numbers on the streets. At

\footnotetext{
${ }^{50}$ Sedghi, 171-73.

${ }^{51}$ Povey, 46.
} 
times, they worked jointly with men to strengthen their position. Sedghi divides these nonconformist women into three categories: secular leftist groups, secular independents and the religious oppositionists. The leftist secular women were mostly an urban Marxist and progressive group, who, although faced with sexism and chauvinism from their male activists, fought to oppose class inequality, repression, and U.S. imperialism. No matter how little the leftist groups spoke of women's rights in Iran or how fragmented their efforts, nonetheless, they were another element in raising the political consciousness of women. ${ }^{52}$ The secular independent women were predominantly professionals who fought within and outside of Iran in countries like the United States and Western European nations. The women were influenced by the American Civil Rights Movement, as well as by the women's movement and growing global anti-imperialism. Many independent women were intellectuals who brought attention to the struggles of the impoverished and criticized the state for exploitation and corruption, using as tools, their research, studies, poetry, or writings. Furuq Farrokhzad (1935-67) is an example of a modern poet who expressed her objection to women's subordination and oppression due to patriarchy in the social and political orders. ${ }^{53}$

\section{The 1979 Revolution and Its Aftermath}

Women of the religious opposition, mostly from the Shi'i sect, became increasingly active in the 1970 s, prior to the 1979 Revolution. They were influenced by the works of Ruhollah Khomeini, Morteza Motahhari and Dr. Ali Shari'ati on issues such as sexuality, gender relations, women's position in the family, and women in the

${ }^{52}$ Sedghi, 162-183; Ghorashi, 69.

${ }^{53}$ Sedghi, 189; Ghorashi, 59. 
workforce and politics. Although works published on these matters helped to raise women's religious consciousness, their authors did not separate religious issues from political discussions of the time. These leaders urged women to take action in opposing the Western-oriented state for its objectification of women, for moral laxity and corruption, and for its secularization of society. This group of women in the opposition movement sought to be pious Muslim mothers and wives who could help form a new ideal Islamic society. Furthermore, they increasingly incorporated the hejab into their lifestyle as a form of resistance to the regime because of its earlier forced unveiling. The became a symbol of protest against Western imperialism and women's objectification. The women practiced hejab (head cover and modest clothes) to demonstrate nationalist pride while remaining critical of patriarchy. ${ }^{54}$

Sedghi argues that, after 1979, control of women's sexuality and the instigation of a system of inequality and segregation encapsulated the Islamic Republic's idea of how to legitimize itself and to identify its philosophy as anti-imperialist and anti-Western. The anti-imperialist sentiment was so strong, even among the secular and leftist organizations, that it overshadowed the movement for gender equality, and it enhanced the regime's ability to implement the $h e j a b .{ }^{55}$ The three main political factions in Iran after 1979 were the Islamists, the leftists and the nationalists. According to Sedghi, these factions were male-dominated and this circumstance privileged patriarchy, rather than women's interests. ${ }^{56}$

\footnotetext{
${ }^{54}$ Sedghi, 193-96; Ghorashi, 60-70.

${ }_{55}^{55}$ Sedghi, 205; Azar Nafisi, Reading Lolita in Tehran (New York: Random House, 2004), 112.

${ }^{56}$ Sedghi, 204-06; Ghorashi, 100-118; Nafisi, 85.
} 
Under the new regime, a Council of Guardians was created, a political agency designed to reinforce executive power. It consists of well-known and respected clerics, who also participate in and dominate the Parliament and other electoral bodies. The Council of Guardians, the president, the cabinet, and the parliament are all accountable to the Supreme Leader. This "mechanism of control allows only one active political party and emphasizes the power of the Supreme Leader and the Council of Guardians over and above that of the President and Parliament." ${ }^{, 57}$ The Council of Guardians is likewise male-dominated, as women are barred from becoming religious leaders. This political arrangement undermines the democratic system by placing executive power in the hands of the clerics, who have not been elected by the people, and by diminishing the authority of elected officials such as the president and parliament members. This patriarchal system and the lack of democracy in Iran greatly impede the realization of gender equality.

In the immediate post-revolutionary period, from 1979 to mid 1981, a power vacuum developed, which resulted in a temporary period of freedom for political activities, for political participation, and for social acceptance of activist women. Even religious leaders encouraged women to leave their homes and take part in the struggle. Women could interact with men at an intellectual level without being harassed. Many women's organizations were formed, and women became increasingly involved in existing leftist groups, such as the National Democratic Front and the Fadaiyan-e Khalq. Political participation taught women how to organize, demonstrate, hold discussions,

\footnotetext{
${ }^{57}$ Hashemi, 164-65.
} 
raise awareness, and demand women's rights, all of which were independent of the political goals of the organizations. ${ }^{58}$

This openness and the opportunities of this era were short lived, as the Islamic Republic officially took over the new government in 1981 through a vigilante-style attack against freedom. It utilized a group of street mobs called Hezbollah to attack and ban any oppositional group that had any hope of participating in the new regime. The Islamic Republic closed universities, purged faculties, censored much of the press, and banned almost all political activities. ${ }^{59}$ Women, whom the Islamic leaders had encouraged to fight against the Pahlavi regime, were now told to return to their homes and to their roles as mothers and wives. As an effort toward cultural independence from the Western model and towards national development, a role for women was constructed based on an indigenous Islamic model and not on the direct interpretation of the Quran. Set in the context of the power struggle of the time, political repression, ideological control, economic challenges, the war with Iraq, and anti-imperialism, this "Islamization" of women came to mean the opposite of the Western values of individualism and individual rights. $^{60}$

Religious leaders considered women's sexuality so dangerous that they advised women to adhere to the modest Islamic clothing and veil (hejab). Khomeini, who had been influential for years, officially became the religious leader of the Revolution by the beginning of April 1979. He required all women to wear the Islamic hejab, despite

\footnotetext{
${ }^{58}$ Ghorashi, 61-67.

${ }^{59}$ Ghorashi, 60-118. Mitra K Shavarini, Educating Immigrants: Experiences of Second Generation Iranians (New York: LFB Scholarly Publishing LLC, 2004), 27-30.

${ }^{60}$ Shavarini, 5; Yeganeh, 8.
} 
numerous protests from religious and secular women. By 1983, the Parliament enacted the Islamic Punishment Law, which demanded seventy-four lashes for any violation of the $h e j a b$, and, in 1995 , the punishment for publicly resisting the hejab was fixed at ten to sixty days of imprisonment. This compulsory veiling was imposed at the workplace, and the refusal of many professional and intellectual women to veil themselves cost them their high official positions such as professors, judges and lawyers. ${ }^{61}$ Along with reveiling came the segregation of all beaches and athletic activities.

One of the first and most important actions taken in the immediate months after the Revolution was Khomeini's abolition of the Family Protection Law. Not only did it become harder for women to instigate divorces, but their husbands automatically received custody of their children. An elected member of a local council, Marzieh Mortazi, stated in support of these new provisions: "If a woman cannot bear a child she is not considered a woman, she can be divorced. If a man wishes to divorce his wife for any reason, her children will be taken away from her." ${ }^{, 62}$ In addition, polygamy was legalized, the inheritance of a woman from her parents became half of that of her brother, and the dress code soon was enforced in all public places. Also indicative of repressive legislation against women, the Bill of Retribution was enacted in 1983, whereby women's testimony in court was fixed at half the value of a man's. Severe punishment could be enforced in case of defiance of the hejab; adultery could be punishable by death; putting on makeup, walking with the opposite sex, renting a place alone, and traveling alone could all subject

\footnotetext{
${ }^{61}$ Nafisi, 85.

${ }^{62}$ Povey, 63-64; Moghadam, 1157.
} 
a women to harassment. ${ }^{63}$ The suspension of the Family Law reversed certain gains women had enjoyed. The age of marriage was lowered again from eighteen years to nine years and it was not until the 1990s that, with the help of many women, it was raised to fifteen. Religious and political leaders such as Ali Akbar Hashemi Rafsanjani sanctioned polygamy and temporary marriages (a contract between a couple to be married for a limited time and approve by a cleric). Gender segregation was implemented at sporting events, on beaches, in some cases in offices, lecture halls and universities, and in most public places, such as on buses, where women were expected to take the seats in the back. The 1997 legislation that segregated all medical facilities limited women's choices in health care. Women found that activities in their private lives, such as weddings or house parties, were often interrupted by guards, who tried to enforce gender segregation and hejab. Drinking alcohol, gambling and listening to music based on love and sexuality - especially Western music - were banned. A wife had to obtain the permission of her husband to leave the country (this was also the case during the time of the Shah, but under his regime one could acquire the exit paper work more easily). Unlike the Shah, who encouraged single female students to pursue their education abroad, the current government until recently prevented single women from pursuing their graduate studies abroad. ${ }^{64}$ An 1985 law provided that unmarried women students might not go abroad to continue their education, on the grounds that it could lead to the moral

\footnotetext{
${ }^{63}$ Ghorashi, $60-100$. On one of my trips to Iran, I was traveling in a taxi with my sister and two of my male cousins. We were stopped by the guards, and forced to sign forms that the four of us were having inappropriate relations. We were kept in jail over night, interrogated separately. It took four days of court visits and a host of family members' efforts to free us from receiving lashes as punishment for being with the opposite sex.

${ }^{64}$ Ghorashi, 71-108; Hashemi, 8-9.
} 
degeneration of female students. This law was reformed in the year 2000 through the ongoing efforts, ever since 1990, by working-class women, but the government still declines to provide any financial assistance to Iranian women students abroad. ${ }^{65}$

Despite the fact that seventy percent of the university students are female and that the literacy rate of Iranian women, in general, is at seventy percent, women suffer a greater socioeconomic disadvantage than men do because they are rarely given access to well-paying and influential jobs. ${ }^{66}$ In a society where jobs became scarce due to the slow economy, the jobs went to men. By 2004 , only 12.5 percent of women living in urban areas were employed. ${ }^{67}$ The government enforced religious and cultural norms which further discriminated against women, according to Povey. ${ }^{68}$ Financial resources for women's education decreased. Because men were considered the head of the family, they enjoyed dominance not only in education but also in entry into technical fields such as engineering and experimental sciences. These latter fields were wholly closed to women between the years of 1980-84. Women's entry into the medical, environmental and human sciences was between only twenty and fifty percent. ${ }^{69}$

In reference to women in the workforce, the war with Iraq created the need for many women to enter jobs in support of the war effort. Some women were accepted in the army, although few of them were at the war front, while some worked in the hospitals and rehabilitation centers or the charitable organizations. Others were encouraged to

\footnotetext{
${ }^{65}$ Povey, 53.

${ }^{66}$ Xin Li. Iranian Women's Rights Severely Restricted. http://learningpartnership.org, (accessed November 10, 2006).

${ }^{67}$ The Iranian Women Studies Foundation. http://www.iranwomen.org,, (accessed November 13, 2006).

${ }^{68}$ Povey, 51.

${ }^{69}$ Shavarini, 12.
} 
marry war veterans. In the aftermath of the war as the economy improved, more women found employment. By 1996, however, the number of women in the labor force remained less than in $1976 .^{70}$

These setbacks only cemented the determination of many women to fight against gender repression. To many leftist women, socialism had meant equal rights, justice, and a classless society. These values also appealed to the lower classes who suffered from economic setbacks during the Pahlavi era. Many women were transformed by their participation in the revolution, for they became politically conscious and aware of their collective power; they refused to give up their fight for freedom and equality easily. Selfsacrifice, suppression of one's needs and pleasures, and even willingness to die for the "cause" were popular ideas during the revolution among both men and women activists, and such were still valued greatly in many political organizations in the immediate postrevolutionary years. Many youth formed their political identity and pursued their commitment to activism with passion while they lost track of necessary security precautions. A large number of them thus were arrested, tortured, and killed when the regime imposed its power by a forceful take-over of the government and immediately suppressed their political activities. Many people labeled this the "black period," as the hard line Islamists claimed the revolution and used violent attacks and suppression in name of protecting Islam. They took every opportunity to publicize the "crimes" of dissidents by publishing in newspapers pictures and names of political activists killed. They tortured others into confessing on national television. All this violence put decisive

\footnotetext{
${ }^{70}$ Sedghi, 33.
} 
power into the hands of the Islamists by June of 1981 as they successfully dismantled political organizations or forced them to go underground. They killed many political leaders and sent others into exile, replacing the mood of optimism and opportunity with one of fear and distrust. ${ }^{71}$

Faezeh Hashemi, a former member of the Iranian parliament, is an example of a politically aware woman who continued in her determination to achieve gender equality in the years after the 1979 Revolution. At the time she lost her parliament seat in the 1996 election, she described the repression of women in her society: "We live in a patriarchal society. Many male members of the Majles (parliament) believe that in a situation where there is unemployment, priority should be given to men. Our judges, who are all men, interpret the laws and regulations in favour of men." ${ }^{72}$

In the immediate post-revolution period in Iran, as regime formation was taking place, Hezbollah, the new force created by the regime, enforced the laws through intimidation, interrogation and jailing. The Hezbolla were particularly successful in enforcing the hejab. Hejab was considered necessary because it concealed the sexual power of women in public, which Islamists claim was a dangerous distraction to men. ${ }^{73}$ Detailed rules were promulgated about how hejab should be implemented (dark colors of gray browns, black or navy were encouraged for use especially in workplace) ${ }^{74}$ Hejab became an institution which not only suggested that women should be modest but also that they should be restrained, chaste, obedient, and subservient to their husbands,

\footnotetext{
${ }^{71}$ Ghorashi, 100-116.

72 Povey, 51.

${ }^{73}$ Sedghi, 210-211.

${ }^{74}$ Nafisi, 4.
} 
fathers, and brothers, performing their sexual duties. Women were regarded as the guardians of Islam, the country, and the nation. Fatemah, the daughter of the Prophet Mohammed, was the role model for women since she was a pious and virtuous mother and wife, as well as a devout Muslim. Sedghi argues that hejab was used to send a message to other countries by the regime to portray an Islamic image of Iran; women were used, in short, as instruments of foreign policy: "gender matters to politics and politics matters to gender." 75 While in the past, veiling took on different implications, in the post-1979 period it meant greater access to education and more mobility. ${ }^{76}$ The veil also came to represent nationalism and Islamic identity. According to Sedghi, the regime controlled gender relations through the hejab. Many women lost their jobs or voluntarily left as a result of their objection to the enforced $h e j a b$, gender segregation, and harassment in the workplace. Secular and religious women who believed that women should have the option to observe the hejab or not to do so protested together. They argued that the hejab desexualized women. ${ }^{77}$ In any event, the combination of factors, enforcement of the hejab, discrimination against women in the workplace, and exhortations by clerics that women return to the private sphere and remain content with the role of wife and mother, served to strengthen the patriarchal system. Culturally, Iranian women identified with being mothers and wives rather than professionals which further reinforced patriarchic system. ${ }^{78}$

\footnotetext{
${ }^{75}$ Sedghi, 210-20.

${ }^{76}$ Ibid.

${ }^{77}$ Ibid., 209-26; Nafisi, 85-98.

${ }^{78}$ Sedghi, 232.
} 
A dissertation written by Susan Seife entitled "Effects of Outside Employment on Lower Class Iranian Women and their Children" at Syracuse University in 1985 shows that "the effects of the revolution have been significant for working women when compared to non-working ones. Married working women have shown lower levels of power and decision making within the family unit after the revolution compared to levels before the revolution of 1979 . Higher levels of homemaking (versus working outside the home), job discrimination, and polygamy have been observed for married working women after the revolution." ${ }^{79}$ However, the married working mothers have enjoyed more marital power than non-working mothers. The cultural changes resulting from the revolution showed an effect on children in that the boys have shown a lower level of homemaking participation, while the girls have shown a higher level in this same area. ${ }^{80}$

The post-1979 regime initially attempted to avoid becoming part of the global economy, as it tried to become independent politically and economically, but the country soon suffered an economic crisis. Some of the factors contributing to this crisis included the freezing of Iranian assets by the United States and an international trade embargo prompted in response to the taking of the American hostages. In addition, the 1980 Iraq invasion devastated the economy. The regime lacked a clear economic plan in the aftermath of the Revolution. Inflation skyrocketed, and food shortages sent many women into long lines for their rationed food supply and gasoline. With many women at home

\footnotetext{
79 Susan Seife, "Effects of Outside Employment on Lower Class Iranian Women and Their Children" (Ph.D. Dissertation, Syracuse University, 1985), "Abstract," quoted in ProQuest Dissertations and Theses. http://proquest.umi.com.libaccess.sjlibrary.org/pqdweb?index $=4 \&$ did $=753957431 \&$ SrchMode $=1 \&$ sid $=1 \&$ Fmt $=2 \&$ VInst=PROD\&VType=PQD\&RQT $=309 \&$ VName $=P Q D \& T S=1257753121 \&$ clientId $=17867$

${ }^{80}$ Ibid.,
} 
and Khomeini promoting larger Islamic families, by 1989, there was a population explosion. The economy, however, failed to provide employment and resources for the increased population. In 1989, the government set in motion its first Five Year Development Plan (1989-1993). Family planning programs, as part of this overall development plan, were designed to lower the fertility rate by encouraging the use of contraceptives and male and female sterilization. In time, fewer pregnancies freed women to pursue education as the economy gradually began to call for women in the workforce again. ${ }^{81}$

Gender segregation plus the re-veiling of women facilitated many traditional families' acceptance of education for their daughters. ${ }^{82}$ The percentage of educated women reached its highest point in Iranian history and remains unmatched by any other Muslim country. As Sedghi notes, "In 2002 seventy-one percent of entry college students were women." In 1994, the government lifted the ban that had closed many technical, scientific and vocational fields to women as well as the quota system that limited the number of women allowed into these fields. Women since have entered into all professions, such as law, medicine and journalism. They have become law enforcers, corporate executives, professors, lobbyists, writers, filmmakers and publishers. This has taken place in spite of difficulties in mobility in traveling and setting up accommodations; the adherence to the hejab, which is more strictly enforced in the work

\footnotetext{
${ }^{81}$ Sedghi, 228-30.

${ }^{82}$ Sedghi, 230-34.
} 
place; gender segregation; sexual discrimination; and the lack of value or recognition for women's work. ${ }^{83}$

Women criticized the government for keeping them out of certain jobs and for not doing more to integrate them into the economy and high-level positions in politics. ${ }^{84}$ In terms of high level government positions, even at this time, only 0.1 percent of ministrylevel jobs and 4.1 percent of parliament seats are held by women. ${ }^{85}$ Women were prevented from becoming religious interpreters or judges despite their theological knowledge, or presidents. Immediately after the revolution, the government permitted their employment in traditional areas such as hygiene, sewing, cooking, and homemaking. Women were allowed to enter medical school in order to study obstetrics, gynecology, pediatrics, dentistry and family medicine. ${ }^{86}$ The growing number of female students has recently troubled some officials who now are debating a quota system once again.

Other discriminatory measures against women in the post-1979 period include the implementation of harsh punishments against them: stoning, beating, whipping, imprisonment, and execution for engaging in adultery, prostitution, or homosexuality. ${ }^{87}$ There have been numerous cases of imprisonment of intellectual women for their political activities. Women such as Shirin Ebadi, a secular lawyer and activist for human

\footnotetext{
${ }^{83}$ Ibid.

${ }^{84}$ Ibid.

${ }^{85}$ The Iranian Women Studies Foundation. http://www.iranwomen.org, (accessed November 13, 2006).

${ }^{86}$ Sedghi, 235.

${ }^{87}$ Ibid. In cases involving female prisoners sentenced to execution, there have been instances in which women first have been raped, following a religious interpretation that calls for virgins to be sexually fulfilled before dying. Sedghi, 208.
} 
rights, especially those of women, had been a judge during the Shah's regime, but after the revolution the law banned women from becoming judges and she was given a clerk's job. Ebadi has since been jailed several times, her life threatened often, and she has suffered a lack of access to political power and institutions. Nonetheless, she has managed to win the Nobel Peace Prize.

Iranian women have not remained passive victims of such legislations. The very same working-class and middle-class religious women who supported the Islamic Republic in the 1980s have become critical of the patriarchal system. The Muslim feminists and secular feminists in Iran have come together, having become conscious of the political, social and economic contradictions, and are taking action to challenge the oppressive measures. These women from different social levels have become united because, as Povey argues, gender discrimination goes beyond class to affect all women. ${ }^{88}$ Povey states, "women in Iran have shown a great deal of courage, imagination and commitment to struggle for their gender interest...struggling for civil and democratic rights." ${ }^{89}$ As Hashemi explains,

the revolutionary experience of 1978-1979 and women's active participation in the movement, and their desire to redefine their role in the family and society in the post 1979 era are vital. The resilience and militancy of Iranian women during the difficult and challenging period following the revolution led to some limited gains in their Labor Force Participation, job opportunities, family law reforms, etc., reversing the original setbacks after $1979 .{ }^{90}$

Women have helped pass many reforms for gender equality. An example is the divorce law of 1984, under which a woman is entitled to half of her husband's estate, but only if

\footnotetext{
${ }^{88}$ Povey, 45,65

${ }^{89}$ Ibid., 69.

${ }^{90}$ Hashemi, 7.
} 
the man had agreed to this in a prenuptial contract. A group of elite women, however, pressured the legislators to pass the Labor Compensation Bill that requires the husband to pay to the wife, in the case of a unilateral divorce and in the absence of a wealth-sharing provision, "the wage equivalent" for working in the house during the years of marriage. Although few women use this provision, it nevertheless provides a new legal advantage. Furthermore, in 2002, women legislators helped authorize female-initiated divorces, although each case still must be endorsed by an Islamic judge. ${ }^{91}$

Another factor affecting women has been the further suppression of the press since the revolution. Legislation in 1997 outlawed the publication of women's pictures on magazine covers or the type of "writings that might elicit sexual tensions between" the sexes. ${ }^{92}$ Shahla Lahiji, a publisher who has written multiple books on women and the law in Iran, explains that "women's writings have been more under scrutiny and censorship then men's writings."93 Women filmmakers tend to be more political as they portray diverse images of women in their films, showing them as workers, mothers, politicians, and lovers. Consistent conflicts over the reforms have led to further crackdowns on publications and to the imprisonment and execution of editors, intellectuals and activists, including many women. ${ }^{94}$

Sedghi divides Iranian women into proponents and opponents of the regime. Proponents are primarily Shi'i women who fought the monarchial regime prior to the revolution with the agenda of uniting the state and religion. Devout, a subgroup of the

\footnotetext{
${ }^{91}$ Sedghi, 231.

${ }^{92}$ Ibid., 243.

${ }^{93}$ Povey, 60.

${ }^{94}$ Ibid.
} 
proponent women, promote Islam through meetings and gatherings at the mosques and religious schools, and they adhere to the hejab as a form of modesty and protection from exploitation. Some of them are more conservative in demanding complete gender segregation while others fight for women's education and equal political rights and oppose discrimination. They do often work with government to implement greater equality for women. ${ }^{95}$ Opponents comprise religious and secular women, who believe that religion is a private matter, and that the state should be separate from religion. Moreover, they believe women should have a choice about the veil. They are primarily urban middle- and working-class women. Sedghi further divides this group into subcategories of rebels, revolutionaries and reformers. They are all dynamic women who have fought for gender equality. In the past, revolutionary women protested the mandatory hejab and the reversal of the family laws, as well as objecting to other discriminatory acts brought about by Khomeini's edict. They engaged in massive street demonstrations, organizational meetings, and lobbying activities. They withstood the harassment and violence of the Revolutionary Guards and achieved temporary success with the government, which eased the compulsory requirement for the hejab and reestablished pre-Islamic Republic norms for enforcement. This did not last, however, as they failed to receive the support of the progressive and leftist men, and violent attacks by the guards preserved the mandatory hejab under Khomeini's edict of 1980 that called for the adherence of hejab for all women working in the public sector. ${ }^{96}$ Although women's resistance did not reverse the reveiling mandate in the 1980s, in the 1990 s more of a

\footnotetext{
${ }^{95}$ Sedghi, 267-70.

${ }^{96}$ Ibid., 250-51; Povey, 56.
} 
unified effort has been made by secular and religious women to become active participants in the social, economic and political issues affecting all of them. While women continued to lose certain rights, such as the reversal of the family law, they became more conscious of gender inequalities and increasingly determined to fight them. $^{97}$

The rebel group of women consists of the younger generation in their $20 \mathrm{~s}$ and $30 \mathrm{~s}$ who have experienced no other system outside of the segregation, veiling, and the discriminatory rules of the regime. However, they have been exposed to personal and civil freedoms enjoyed by other women in other societies through modern communication tools such as the internet and satellite TV, as well as through publications by émigrés as Iran becomes more integrated into the global economy. They too fight the reveiling by redefining the shape, design, and color recommended for the hejab. ${ }^{98}$ Reformers comprise former revolutionaries who have dedicated their lives and careers to advocate democracy and women's rights. Shirin Ebadi is a reformer who believes that society has to be ready to change its patriarchal systems and treatment of women and believes that changes only in the laws, such as the Shah had done to some extent, could not by themselves change the situation of women. Mehrangiz Kar, another reformer and lawyer, criticizes the Muslim reformers who promote the idea that men and women were born to fulfill different roles and who thus rationalize the subjection of men and women to different laws within the family. ${ }^{99}$

\footnotetext{
${ }^{97}$ Povey, 56-60.

98 Sedghi, 253.

${ }^{99}$ Ibid., 55; Povey, 55.
} 
In general, religious women have greater access to political power than secular women through political or official positions in the regime. ${ }^{100}$ A larger group of women, as the result of gender segregation, hejab and the impact of the war, have had greater access to education and employment. ${ }^{101} H e j a b$ and segregation of the sexes after the revolution, Roksana Bahramitash and Povey argue, gave a wider group of women the opportunity for education and social movement since traditional families found it safe for their daughters to go to the all-girl schools where they would observe the hejab at all times. Iran has been a Muslim country for more than one thousand years, and veiling has been part of Iranian women's history. This is partly why many Iranians found it difficult to accept the westernization of the Shah's regime. ${ }^{102}$

Islam is not necessarily opposed to modernity, argues Fariba Adelkhah. Rather it can be used as yet another tool such as politics, culture or the economy to achieve modernism. ${ }^{103}$ Valentive Mogahdam argues that intellectual women abroad have endorsed expressed hope in the growing Islamic feminism within Iran. Although the term has referred to women who are trying to interpret the Quran in search of egalitarian tendencies and this might be limited at times, the feminist interpretations have had much social force to support them. ${ }^{104}$ The death of Khomeini and the election of Mohammad Khatami is another example of moderation. Khatami, a reform minded candidate, won the election virtue of the votes he garnered from many women and young people

\footnotetext{
${ }^{100}$ Povey, 46.

${ }^{101}$ Povey, 47.

102 Povey, 46-49; Mongol Bayat, Iran's First Revolution: Shism and the Constitutional Revolution of 19051909 (New York: Oxford University Press, 1991), 5.

${ }^{103}$ Fariba Adelkhah, Being Modern in Iran (New York: Columbia University Press, 2000 ), 10.

${ }^{104}$ Moghadam, 1143, 1159-60.
} 
especially. His reforms brought some positive changes for women. Khatami's election is the consequence or the evidence of the need for democratic reforms and economic demands by women and the large youthful population. The theocratic regime is struggling to harmonize the will of the people with religious ideology, according to David Menashri. $^{105}$

The tumultuous social, political and religious history of gender in Iran, often at the heart of many conflicts, has brought to Iranian women an awareness of gender equality. At times during the twentieth century, they encountered a degree of democracy and independence during the modernism and secularization efforts of Pahlavi. This awakening to the possibilities of equality has not been reversed entirely, and their quest for freedom has brought many of them to the United States.

\footnotetext{
${ }^{105}$ Moghadam, 1141; David Menashri, Post Revolutionary Politics in Iran: Religion, Society and Power (London: Portland, OR: Frank Cass, 2001), 51.
} 


\section{Chapter III.}

\section{Immigration}

It is important to set forth prior research on Iranian immigrants, as well as recent scholarship on gender in order to put participants' answers in context and to interpret fully this new data. This study looks primarily at the work of the researchers Mahasti Hashemi and Mehdi Bozorgmehr. Migration is a complex process that involves multiple factors. This study adds to the existing work on the question of how two important components, gender and patriarchy, contribute to the understanding of migration. Iranian women, according to Hashemi's research, have enjoyed and achieved greater power through migration. She has measured this power through the increase in gender consciousness and through the transformation of gender roles that has come with education and economic opportunities. ${ }^{106}$ Hashemi's study shows that Iranian women immigrated to the United States not only for social and political reasons, but also for economic reasons as well. She notes that Ervand Abrahamian and Darius Rejali, in their earlier studies, found that economic explanations alone did not account for the reasons that the majority of immigrants came from Iran in the past 25-30 years and that political factors were important considerations. These immigrants in these earlier studies were either exiles or refugees. Certainly, their migration was not entirely voluntary. ${ }^{107}$

The initial reasons for migration and the actual process might differ among the Iranian immigrants. Some came before the revolution while others came afterwards, but they all agree that they have decided to stay here for reasons of both socioeconomic

\footnotetext{
${ }^{106}$ Hashemi, 7.

${ }^{107}$ Hashemi, 79, 296.
} 
opportunity and religious and political freedoms. Whether the immigrants came from the first wave only, seeking an education or coming just as visitors prior to the 1979 revolution, or whether they are from the larger influx of Iranians post-1979, who often came as self-exiled persons or refugees avoiding repression, they have decided to make the United States their home. ${ }^{108}$ The decision for many women to stay in America may be traced largely to the social and political patriarchy deep within Iranian culture and to the legal system, which has been hardened by Islamic fundamentalism since 1979. The thousands of women those who fled the country, with their families or alone, were burdened on two levels: they were persecuted for any anti-regime political activity and they suffered the loss of many legal and civil rights. ${ }^{109}$

In the decade following the revolution, the United States admitted the largest number of Iranian refugees. Iranians preferred the United States because of their familiarity with its language, as English was taught in Iranian high schools. The American cultural context was especially familiar to those who lived through the Shah's Westernization, and it offered continuity in habits and life style, specifically hard work ethics and consumerism. ${ }^{110}$ The American attraction was especially true for the majority who came from Tehran, the most populated and most developed state in Iran. These people had experienced modernization and exposure to Western culture during the time of the Shah. In addition, the weather in California, where most of the Iranians reside, was comparable to that of Tehran. Another reason many Iranians chose California was the

\footnotetext{
${ }^{108}$ Ibid, 164-5; Ghorashi, 137-152.; Roger Waldinger and Mehdi Bozorgmehr, eds., Ethnic Los Angeles (New York: Russell Sage Foundation, 1996), 373.

${ }^{109}$ Hashemi, 164-5.

${ }^{110}$ Ghorashi, 155-7.
} 
presence of the Iranians who had come between 1950 and 1977. The earlier group was an educated and highly skilled upper class, mostly politicians and performers, who had settled in the upscale parts of Los Angeles, such as Beverly Hills. This earlier group had used its experience and resources to build a network of political and cultural establishments. ${ }^{111}$ The second group of Iranian immigrants, coming since 1977, has been a more heterogeneous group coming from different ethnic and religious backgrounds. The diversity among this group allows its members the freedom to choose their own identity, rather than being subject to traditional roles. Furthermore, Iranians are generally considered Caucasians, and thus find themselves exposed to less racism. Their high socioeconomic status has also enhanced their acceptance. ${ }^{12}$ In addition to this, America historically has been the land of immigrants, a heterogeneous society that is composed of every ethnic and racial group, especially in California where over one-third of the population is foreign-born. Diversity is celebrated in California, instead of assimilation: the "salad bowl" theory has replaced the "melting pot." All these factors have allowed Iranians who reside mainly in California to experience a greater level of acceptance as another part of the diverse society of immigrants. This feeling of acceptance has defused an inclination to define Americanism as the "other." Iranians celebrate many American cultural traditions and see them as opportunities to incorporate

\footnotetext{
${ }^{111}$ Waldinger and Bozorgmehr, 373-75; Mohammadreza Hojat, "Gender Differences in Traditional Attitudes Toward Marriage and the Family: An Empirical Study of Iranian Immigrants in the United States," Journal of Family Issues 21, no. 4 (May 2000): 419-22.

${ }^{112}$ Shavarini, 44; Ghorashi, 135-152.
} 
Persian practices, foods and family gatherings. ${ }^{113}$ The United States meets their sociopolitical as well as economic needs.

One of the most important reasons for the availability of economic opportunities and legal right to women of all nationalities and races in America is due to the efforts and successes of the feminist movement in this country. From the struggles of women to gain the rights to vote to the efforts to pass the ERA, the continuous fight against sexism and for equal pay and treatment of women has been crucial to civil rights, better health, and greater economic gains for women in the United States. Iranian women in the United States may choose blended roles rather than being subjected only to the traditional Iranian role or forced to assimilate fully into a dominant culture. In the United States, Iranian women are more likely to be able to be critical and selective about their values based on their individual needs. The freedom to maintain these communities openly and be considered part of the American national identity, part of the tapestry of America's multiculturalism, has helped them contribute to and claim part of the society, feel accepted, and remain here. ${ }^{114}$ Overall, the political, religious and social freedoms in America have helped Iranian women to obtain education and communicate many of their grievances.

\footnotetext{
${ }^{113}$ Ghorashi, 183.

114 Amin, 213.
} 


\section{Chapter IV.}

\section{Gender}

Current scholarship looks at gender as a key element in understanding the implications of immigration. Incorporating gender into immigration studies provides a more comprehensive understanding of the immigration phenomenon that has contributed to the formation of American society. In turn, the various practices, identities and institutions that are involved in and affected by immigration can inform us about gender issues among immigrant peoples. Hashemi refers to the ways in which gender becomes incorporated into immigration factors and cites Hondagneu-Sotelo for the following proposition:

Patterns of labor incorporation, globalization, religious practice and values, ethnic enclave businesses, citizenship, sexuality, and ethnic identity [may be] interrogated in ways that reveal how gender is incorporated into a myriad of daily operations and institutional political and economic structures. ${ }^{15}$

The within study will examine these factors in connection with first-hand information from a group of Iranian women immigrants from both the pre- and post- 1979 eras. The data collected from these women becomes especially significant when one considers that the women who can recall the era of the Shah are now aging and their information and insights may be lost if not soon gathered for study and research.

The first point to understand about gender and immigration is the importance of relative economic power between men and women in determining gender inequality. Gender equality is most evident where economic power between men and women is also

\footnotetext{
${ }^{115}$ Hashemi, 242.
} 
more equal. ${ }^{116}$ In traditional Iranian culture, given its patriarchal structure, there exists a division of labor between men and women, under which the men are expected to be good financial providers for their families, whereas the women have no such obligation to support their family financially. The within paper argues while men might emigrate primarily to find economic opportunities, women immigrants would not necessarily have the same primary purposes and might very well have political and social objectives uppermost in their minds. In any event, scholars generally agree that such a division of labor works to the detriment of women's economic power, hence towards gender inequality. ${ }^{117}$ Upon arrival in America, however, men and women then experience a transformation in the economic balance between them. Women now can get jobs and establish financial independence, which in turn transforms social behavior. They acquire an enhanced social status and approach gender equality. One way this equality is achieved is by their proving to themselves and to society at large that they can go beyond domestic chores and to do a "man's" job. This new status for women seems to goes hand and hand with the men's loss of public and domestic status. Pierrette Hondagneu-Sotelo makes this point for Spanish-speaking immigrants to America, and Hashemi then cites this observation with approval with reference to Iranian immigrants as well. ${ }^{18}$ In addition to the division of labor, the impact of industrialization and modernization, combined with religious and cultural factors, need to be addressed in explaining the role of women in the Iranian labor force and the connection of gender

\footnotetext{
${ }^{116}$ Ibid., 239

${ }^{117}$ Ibid.

${ }^{118}$ Ibid., 240
} 
issues to subsequent immigration during the post-1979 period. The process of industrialization and modernization in Iran under the Shah created the need for women to enter the labor force to some extent. The persistence of social patriarchy since the 1979 Revolution, in conjunction with a downturn in the national economy, however, has since created complications for women, especially for educated women who seek to be active participants in the industrialized society and wished to preserve the financial independence that had empowered them to negotiate further their own gender roles. ${ }^{119}$ Haghigat argues that in countries such as Iran where oil is the main source of revenue and the government controls the oil industry, the government's role becomes crucial in influencing women's labor force participation. In the countries of the Middle East where the patriarchal system is part of the Islamic ideology and is appropriated by the state, female labor power is at the mercy of these regimes rather than open market of capitalism. She explains further that when women are needed to support economic development, these governments incorporate women into the labor market. However, when society faces economic downturns and there is a high unemployment rate among males, governments turn to Islamic ideologies to suppress women's equal access to work by emphasizing traditional gender roles as a way to deflect attention from economic failures. This situation becomes acute when high fertility rates in these countries create overpopulation and there is not enough work Women are simply pushed back into the domestic arena. ${ }^{120}$ Culture, religion, tradition, the government, and the economy thus all combine in Iranian society to sustain patriarchy. Women naturally desire to express their

${ }^{119}$ Ibid., 239.

${ }^{120}$ Hagighat, 2-5, 6-7. 
grievances and to foster identities beyond prescribed roles. Upon arrival in America, Iranian women are eager to take advantage of the freedom to do exactly that.

According to Persis Karim, Associate Professor of English and Comparative Literature at San Jose State University, the past six years have seen "an explosion of memoirs written by women of Iranian heritage that discuss the loss and nostalgia from having to leave their home country, as well as taboo topics such as sexuality and love."121 She adds, that women of Iranian diaspora are "remaking themselves anew" and "feel more of an urgency than men to represent themselves to the outside world." ${ }^{\text {,122 }}$ She said, "This stems in part from a reaction to the media's depiction of Iranian women concealed by veils and seemingly without a voice. But they also want to represent themselves because they, in some ways, never had that opportunity."123 Karim has published two books: A World Between: Poems, Short Stories, and Essays by Iranian-Americans and Let Me Tell You Where I've Been: New Writing by Women of the Iranian Diaspora. Both are anthologies of writings by Iranian women, a selection of fiction and nonfiction that explore their history, war, exile and immigration.

The quick adoption of opportunities for self-expression by Iranian women is part of a greater adoption of American egalitarian values. The women are open to change

\footnotetext{
${ }^{121}$ Persis M. Karim and Al Young, eds., Let me Tell You Where I've Been: New Writings by Women of the Iranian Diaspora (Fayetteville, AR: University of Arkansas Press, 2006), 2, quoted in Stephen Kaufman, "Iranian Women in Exile Finding Voices Through Literature: Lack of censorship spawns creative outlet for women to tell their own stories," .Payvand's Iran News 11/07/06, http://www.payvand.com/news/06/nov/1079.html (accessed November 10, 2006.)

${ }_{122}$ Ibid.

${ }^{123}$ Ibid.
} 
since they often find their own culture inhibiting. They have questioned the traditional marriage roles and limitations on their sexual freedom.

Sociological and psychological studies of immigration and acculturation have revealed that identification with and adoption of both the American and the native cultures result in healthier adjustments in immigrants, compared to complete assimilation. This process is labeled the bicultural hypothesis: the United States allows the space for a hybrid culture. ${ }^{124}$ When the rates and types of acculturation among Iranian women and men were analyzed in a study of 110 Iranians (51 females and 59 males), women were seen to adopt modern values concerning the role of women in America at a faster rate than men did. The questions in the study ranged from child rearing practices to the role of women in the family and society to preferences about food, language and music. Men typically held on to their traditional expectations of women and sought to maintain their own superiority. ${ }^{125}$ Another empirical study done by a group of Iranian sociologists compared the attitudes of Iranian male and female immigrants in the United States towards marriage and family. The study included 160 Iranians (61 men and 99 women) between the ages of 20 and 50. The questions asked about their positions on birth control, virginity before marriage, sex education, and the role of parents in relation to their children. This study revealed that Iranian women showed a greater acceptance of the egalitarian and liberal attitudes toward marriage and family than did men. ${ }^{126}$

\footnotetext{
${ }^{124}$ Shireen Ghaffarian, "The Acculturation of Iranians in the United States," The Journal of Social Psychology 127, no. 6 (May 1987): 570-71.

${ }^{125}$ Ibid., 569.

${ }^{126}$ Hojat, 421-34.
} 
Although faster acculturation and access to work and school has brought many women of the Iranian diaspora numerous social and economic benefits, they have also experienced rejection and family conflicts as their new-found freedoms clash with traditional expectations. In the process they have challenged patriarchy and reorganized family power dynamics in accordance with the changes in gender roles. A divorce rate of 66 percent and family conflicts are evidence of the incompatibility of American values and freedoms and traditional values and cultural expectations. This has caused "interpersonal and intrapersonal tensions" that force Iranian men to give up some of their privileges and leads to marital instability and intergenerational discord between parents and children. $^{127}$

Despite these challenges most Iranian women prefer to remain in America and enjoy the many individual rights available to them. They form their identities based on a personal selection from the two cultures and value systems. Bozorgmehr's research on Iranian immigrants in the United States suggests that there is a lack of ethnic and national solidarity among Iranian immigrants in America. Although this may not be beneficial to the community as a whole or to the individual at some levels, it does allow for a degree of individualism away from the pressures and constraints of traditional patriarchy in the cases of women immigrants. ${ }^{128}$ The strength and survival of these women, particularly those previously politically active can be attributed to their feminist, socialist and internationalist ideologies that often saw the world as their home. Their revolutionary

\footnotetext{
${ }^{127}$ Hojat, 421, 30.

${ }^{128}$ Mehdi Bozorgmehr, "From Iranian Studies to the Study of Iranians in the United States" Iranian Studies 31, no. 1 (1998): 25.
} 
training made them disciplined and self-critical; their experiences with sexism and oppression motivated them to seek, appreciate and preserve women's rights.

Furthermore, they have passed on these values to their children who also reflect their pride and interest in their nationality and love for education and freedom. ${ }^{129}$ "Whole generations of young people growing up in the U.S. who are influenced and interested in Iranian culture . . are trying to find ways to address that interest." ${ }^{, 130}$ A great example of this generation is Azadeh Moaveni who was born in America to Iranian parents. She studied journalism in California and spent two years in Iran studying gender relations among the Iranian youth from 1999 to 2001. Her book Lipstick Jihad, discusses the discontent and frustration of the youth with the constant government repression of the press, entertainment, and sexual freedoms. ${ }^{131}$

Iranian women's strength and perseverance does not imply that they never experience isolation, homesickness, and longing for their birth country and culture. They carry a sense of guilt, at times, for having left many behind. Often they feel disloyal to their birth country for not staying behind and fighting like many others. They worry about not preserving their culture, history, and language through their children. Women have been very expressive in their books, poetry, and songs about the struggle in their journeys, their feelings of ambiguity about the future, and the loss of the warmth and familiarity of their home country and family support in Iran. The faster acculturation by Iranian women does come with some side effects such as depression and anxiety, as they

\footnotetext{
${ }^{129}$ Shavarini, 81.

${ }^{130}$ Kaufman.

${ }^{131}$ Azadeh Moavani, Lipstick Jihad: A Memoir of Growing Up Iranian in America and American in Iran (New York: Public Affairs, 2005), 21-84.
} 
find themselves rejected by the traditional Iranian men for being too Americanized and not as compatible with the values of their male counterparts. ${ }^{132}$ In addition, some Iranians have experienced prejudice in the United States on racial or religious grounds. In the aftermath of the seizure of the American hostages, Iranians in America were harassed and arrested. There was much anger and discrimination against Iranians to the extent that some other Middle Easterners who looked like Iranians felt compelled to print their nationality on their T-shirts or their nametags. President Carter ordered an investigation into the visa status of Iranians in America, giving them one month to report to the Immigration and Naturalization Services. ${ }^{133}$ The media had already been negative towards the Iranian revolution in portraying Iranians as violent and anti-American, "religious fanatics," and "backward" without providing the full context and historical development of the revolution. Negative coverage increasingly fueled anti-Iranian sentiments as the hostage crisis lasted 444 days. Mohsen Mobasher quotes Edward Said who criticized American media coverage of Iran at this time, saying that it was “superficial, imbalanced, inaccurate, ethnocentric, ideologically driven and noninvestigative, and lacking in depth."134 An Iranian female student recalled: "It was difficult enough to survive on my own away from home, but it was much more difficult to worry about a possible deportation .... At the same time, I was expected to adapt to

\footnotetext{
${ }^{132}$ Hojat, 422; Karim, xxiii.

${ }^{133}$ Mohsen Mobasher, "Cultural Trauma and Ethnic Identity Formation Among Iranian Immigrants in the United States," The American Behavioral Scientist 50 (2006): 105.

${ }^{134}$ Ibid; Flora Keshishian, "Acculturation, Communication, and the U.S. Mass Media: The Experience of an Iranian Immigrant," The Howard Journal of Communications 1, no. 2 (2000): 99.
} 
the host culture and was being pushed away by it."135 Twenty-two years later, in the immediate aftermath of 9/11, many Iranians were rounded up, interrogated and even deported. ${ }^{136}$ Occasional acts of violence were reported against Iranians whose religious practices or appearance identified them.

Despite this discrimination, Iranian women choose to remain in this country and educate the public on their heritage and fight stereotyping. These women prefer life in America for its social, political, and religious freedoms that offer them independence. Other signs of their commitment to remain in the United States include acculturation, marrying Americans, and participating in politics and social activities here. They choose their careers based on professions needed in America, which suggests their plans are to remain here. They are consistent in efforts to bring family members from Iran and often promote education in America for their children. ${ }^{137}$

Iranian women with their immigration experience have been able to modify their cultural values, gain a level of independence and have more control over their own finances, all of which forces a renegotiation of the power structure within the family. They have become more enlightened and empowered as they surmounted the process and challenges of immigration and acculturation. They have come to ask for even more

\footnotetext{
135 Keshishian, 99.

${ }^{136}$ Pezhvak Magazine, http://news.newsamericamedia.org, 12-7-06. I had a conversation with an Iranian man named Saied who is the owner of three small Persian grocery stores in northern California. He complained about the several occasions that the FBI had interrogated him for being Iranian and sending money to Iran. He had to prove that the money he sent to Iran was in fact spent on purchasing Persian groceries and not for the support of any terrorist activities.

${ }^{137}$ Shavarini, 83.
} 
equality and rights as they have come to have more control over the shaping of their lives. 


\section{Chapter V.}

\section{The Study}

\section{Methodology}

This empirical research examines the circumstances of fifteen Iranian women participants, who have immigrated to the United States and have become permanent residents here from 1964 to 2000 . They come from different socioeconomic backgrounds in Iran and from lower to middle class status in the Unites States. Their ages ranged from the mid-thirties to seventies, with most in their thirties and forties. Three of the women immigrated here prior to the 1979 Revolution and rest of the respondents afterwards. They were solicited through several Iranian organizations such as the Zanan group, Iranian Women Federation, and other cultural organizations such as Farsi schools and Dance academies. There were also friends and acquaintances that trusted the confidentiality of this study and its author. Their trust yielded several referrals of participants from the above organizations. Many of the publications on Iranian women have been written in the form of autobiographical or political statements by educated and activist Iranian women in America and abroad. The group chosen here is comprised of an underrepresented majority who has not yet told its stories and grievances. The questionnaire for this study (see Appendix B) asked the women to describe their immigration process; to describe their causes of migration as well as expectations and challenges of life in America; and to explain the changes they have experienced in their personal and professional lives, especially as women. They were also asked about the enforced $h e j a b$ for women in Iran and, in general, their views of the legal and social 
status of women there versus that of American women. Finally, they were asked to compare Iranian men living in the Unites States to those living in Iran and also to American men. ${ }^{138}$ Almost all of the participants came from urban settings in Iran, mostly Tehran, the capital of Iran and the most populated and developed state. Historically, most of the Iranian immigrants to America have come from Tehran. Having been more exposed to westerners and western or modern lifestyles, they have been better able to afford the high cost of immigrating to the United States. The fact that the majority of the participants were urban women was helpful to this research project in that they were more likely to be gender conscious, having lived in a more modern state with a homogenous culture and language (Farsi). ${ }^{139}$ They were either part of the workforce or were exposed to other women in the work force. They have seen women active in the political and social scenes. Some of them have experienced the differences and transitions in the treatment of women between the two regimes, the Shah's regime and the Islamic Republic, that made them more conscious of gender issues. They also had more economic and educational opportunities that helped them be more expressive and analytical. They all showed apprehension about being recorded or having their real names used for the fear of persecution by the regime in Iran. Their fears and concerns were present and imminent despite the large geographical distance between their residence in this country and Iran, even though many had no intention of returning to Iran to stay. They still carry the fear they had once experienced in Iran or feel during their

\footnotetext{
${ }^{138}$ The participants' responses were a mixture of Farsi and English and were either collected through oral interviews or written by the participants. The Farsi was translated by the author. All responses cited herein are set forth in full in Appendix A.

${ }^{139}$ Sedghi, 5.
} 
visits there. As a result, I refer to the participants using pseudonyms. Some women refused to participate in the study despite the reassurance of anonymity and confidentiality. Except for one participant who allowed her voice to be recorded, all the women preferred to write or have me write their responses. There was one participant whose fears caused her to give very short answers to each question, yet she tried to remain positive toward the regime. She said she did not want to go to college in Iran because the entrance exam was too difficult. Although she had visited Iran several times since her immigration to the United States, she was not aware of any woman in Iran objecting to the hejab or treatment of women. She kept repeating that she is proud of being Iranian. Those participants who lived through the Shah's regime had more complaints about the new regime; its enforcement of the hejab; the reversal of family laws; and the lack of legal rights. The general consensus among them, both in casual and formal interviews, was that there are definitely more sociopolitical freedoms and economic opportunities for women in America than there are in Iran under the present regime. The responses of the participants in this study confirm the findings in existing research on Iranian immigrants by Bozorgmehr, Abdolmaboud Ansari, Ghorashi, Hashemi, and Sedghi, among others, to the effect that Iranian immigrants can be divided to into two groups: those who immigrated a few years prior to the revolution mainly in search of technical education to serve the rapidly industrializing Iranian economy and those who immigrated after the revolution as exiles or refugees because of opposition to the regime and fear of persecution. 


\section{Pre-1979 Immigrants}

The development of the oil industry in the Middle East required skilled labor from the developed countries such as Great Britain and the United States and they extracted most of the oil profits and paid little minimal royalties to the local governments. This was one of the factors contributing to the anti-western sentiment that later evolved into uprisings in some Middle Eastern countries such as Iran. To achieve control over their own oil industry, some of the countries began to send young people to western countries for technical education. With the formation of OPEC (Organization of the Petroleum Exporting Countries) in the 1960 s and the independence of several former British protectorates such as Qatar, United Arab Emirates, and Bahrain, these countries gained greater negotiating power in regards to their oil prices. ${ }^{140}$ In the 1970 s, the Iranian economy in particular grew at a fast pace as a result of the development of the oil industry. This surge in development applied to the countries in the Arabian Peninsula as well. Migration from the Western Asian countries had been increasing with the discovery of oil in the Persian Gulf and the Arabian Peninsula between 1930 and 1950. In Iran, as wages began to increase, so did the need for skilled labor, which caused temporary emigration to developed countries, such as the United States, for education and training. These circumstances also created the need for women to enter the workforce. ${ }^{141}$ The inter-Asiatic migration in particular increased with the economic boom caused by the rise in oil prices beginning in 1973. In the United States, President Lyndon Johnson had

\footnotetext{
${ }^{140}$ New York: U.S. Department of Economic and Social Affairs Population Division, Levels and Trends of International Migration to Selected Countries in Asia-United Nations, 2003, 1-11.

${ }^{141}$ J.S. Briks and C.A. Sinclair, International Migration and Development in the Arab Region (Geneva: International Labour Office, 1980), 21.
} 
signed into law the Immigration and Nationality Act of 1965 . The new immigration law abolished the national-origin quotas set by the previous Immigration Act of 1924 . Now that United States had become an economic superpower and there was much unrest against racism at home, so it seemed timely to change the discriminatory immigration policies to reflect new liberal ideologies, which valued diversity and globalization. Under the new law, 170,000 visas were allowed annually for immigrants from the Eastern Hemisphere and 120,000 visas for immigrants from the Western Hemisphere, with no more than 20,000 per country. The number of family reunifications, also labeled "chain migration," however, was unlimited. There was a slight increase in number of women immigrants and an increase in the education and skills of immigrants, which is referred to as the "brain drain." This policy of allowing unlimited visas to family members shifted the types of immigrants to America from those of European descent to Latin American and Asian groups. In this climate of receptivity to immigration from non-European countries, women came to the United States, having been provided the opportunity not only to enter the work force at home, but also to migrate from their homeland abroad. ${ }^{142}$

In the midst of the Cold War and with the repressive regimes that sometimes followed decolonization, and because of war and conflicts in the decades from 1970 to 1990 , the number of countries generating refugees grew from twenty-five to fifty. The number of refugees grew from nine to seventeen million. In Iran, specifically in the period after the 1979 Islamic Revolution, a repressive authoritarian regime caused two to

${ }^{142}$ Vernon M. Briggs and Stephen Moore, Still an Open Door? U.S. Immigration Policy and the American Economy (Washington, D.C.: The American University Press, 1994), 16-17. 
three million people to leave the country. As Aristide Zolberg and Peter Benda-Berghahn stated in their work, "Illiberal democracies - those that combine the right of political participation with the absence of many civil and minority rights, may indeed generate sizeable emigration, especially if they also lack affluence. Such illiberal democracies as contemporary Iran [current regime] and Sri Lanka demonstrate some of the patterns." 143

Susanne Schmeidl further confirms the above argument and the argument in this study that the cause of immigration can be sociopolitical and not just economic. "It is argued that refugees usually come from very poor countries, hence economic causes could be considered as a 'root' or primary cause of refugee migration. Yet the data examined here shows that while refugees indeed come from poverty-stricken countries, not all poor countries send refugees. This disqualifies poverty as a direct and necessary push factor of refugee migration.",144

Many of the women in this study reflect the operation of these factors in their decision to move to America before 1979. Three women in this study arrived in America prior to 1979. Zahra came to America just a year before the revolution at the age of fifteen as an exchange student to pursue higher education. She said she decided to stay in the United States after she had completed her education. She had learned that in the aftermath of the revolution further loss of civil and legal rights especially for women had occurred in Iran. Although she did not come to the United States with the intention to

\footnotetext{
${ }^{143}$ Aristide R. Zolberg and Peter M. Benda-Berghahn eds., Global Migrants, Global Refugees: Problems and Solutions (New York: Oxford University Press, 2001), 243-5, 264-5.

${ }^{144}$ Ibid., $64-82$.
} 
stay, she did decide to remain for political, religious, and social freedom. ${ }^{145}$ Afsaneh came to the United States long before the revolution, in 1964, as an electrical engineering student. She had found the political and social constraints of the Shah era unbearable and she had no wish to return. It was difficult to stay in Iran beyond a few weeks, and she would never consider moving to Iran under the current regime, which she finds considerably more oppressive than that of the Shah's era. Her story suggests that regardless of the time of immigration, the nature of the current regime acts as a deterrent for stay in Iran. Bita came here in 1974 at the age of fourteen along with her brother and parents. Her parents wanted their children to receive a good education in America, but they did not intend to return to Iran. She immigrated with no intention to return to Iran. The situation of these three participants confirms earlier points that before the revolution, immigration occurred for educational purposes.

\section{Post-1979 Immigrants}

After the 1979 Revolution, emigration from Iran took on a decidedly political cast. A majority of the respondents in this study came to America after 1979 and all have expressed dismay at the lack of legal and civil rights in Iran, specifically for women, as well as suppression of the press and media. They also comment upon the resilience of social and legal patriarchy that they experienced. This is not to say that the Shah's regime was ideal; it too suffered from corruption, an increasing gap in wealth distribution, and lack of political freedom. After the revolution, knowing the new regime to be oppressive and with a fear of persecution, thousands of Iranians emigrated to the

${ }^{145}$ See Appendix A of this paper. All references to study participant responses in this thesis is to Appendix A. 
United States. Although some of the participants in this study were young when they immigrated, their families were determined to make a life here and endured many challenges in the process of migration as well as acculturation. The following twelve participants summarize their reasons for immigrating post-1979.

Faranak explains,

I came here when I was nineteen years old in 1990 through [a] relative visa. The 1979 revolution changed everything for my family. We no longer could have a peaceful life in Iran. There was so much unrest and with the added pressures of the Iran-Iraq war my family decided to leave for the United States with the intention for a permanent stay. We definitely came here for the political and religious freedoms. My dad had been a translator for the Shah as political figures visited Iran. This in itself was considered an affiliation with the Shah's regime. We experienced much harassment and prejudice by the government and people for being associated with the Shah.

Faranoosh came here at the age of seventeen in 1988 with her only brother. She wanted to go to school here. Her family intended fully to support her decision since it did not want either one of its children to live under the current regime.

Sara came to America in 1996 through marriage to an Iranian man at the age of twenty. She does not remember the revolution since she was only three years old at the time. She explains that life was especially difficult for women in the immediate years after the revolution and that she thought her husband was going to take her to "heaven" in America with all the freedoms she could enjoy here.

Fari came here at the age of thirteen in 1985 with her mother and sister. Her single mother had decided after the revolution to bring her two daughters to America to join her son and have the whole family make America its permanent home. Fari remembers going to the American Embassy in Turkey for her visa and seeing long lines of Iranians 
waiting long hours for an opportunity to apply for American visas. Many had disrupted their lives in the hope of coming to the United States with no alternative plan.

Mina came to America as a single mother in 1986 with every intention to stay in this country. She had two daughters, ages twelve and thirteen, whom she wanted to bring with her to America. Although she obtained a visa, her two daughters were denied. She was forced with much grief to separate from her two girls. She says,

I couldn't leave my daughters, but at such a young age they were so smart and determined to not go back to live in Iran that they convinced me to leave them behind. They told me that they were willing to tolerate the sadness of being away from me for a few years if it meant that eventually they could come to the United States through [a] relative visa. If I stayed with them in Iran, they may have never had the chance to come here. I had to send them to stay with some family members in Italy for three years while I tried to establish residency. I married an American man to gain my green card, so I can apply through family visas for my daughters. It cost me ten thousand dollars for each one of my girls to have a lawyer help me process their immigration.

She also says: "I decided to move to the United States so my daughters can have better

lives and have more freedom to do and wear whatever they wanted and to have a better education free of religious requirement."

Azar reports,

I came to the U.S. for the first time in 1969 to visit my daughter who was going to school here studying economics. I then visited several other times before the revolution. I brought my son here who was thirteen years old to stay with my daughter. Two years after the revolution, getting an American visa became increasingly difficult. The consulates knew that after the revolution Iranians would no longer just visit the U.S. They would come to stay and since the relationship between the two countries had been damaged the visas were given with many conditions that would guarantee your return to Iran such as having young kids in Iran or a large amount of wealth. I applied with my other daughter who was under eighteen. I had to pay about six thousand dollars, which at that time was a lot of money, to a lawyer, plus my daughter in America had to show that she could financially support us during our stay here. I was finally able to 
come here with my daughter after going to Turkey first then waiting three years in Germany which was very difficult since we didn't speak the language and didn't have most of the comforts we enjoyed in Iran. My husband was still in Iran, and it took years for him to join us in the Unites States. We had come with every intention to stay because life had become so difficult in Iran. At one point in Tehran, due to fear of protestors, the government only allowed the doctors and some other professionals to drive their own car. The city was too restless and [so] unstable that government was afraid of allowing the usual mobility to people and to make matters worse, the cost of gas had skyrocketed.

Sharareh came to this country in 2000 at the age of thirty-three through marriage to an Iranian man who had spent years here and was ready to start a family with a woman from his home country. She only knew him for two weeks before they were married. Her family was somewhat familiar with his family. She says she had the choice to say no, but she wanted to come to the United States. "I thought he would be ok."

Mojghan visited the United States in 1973 as an exchange student when she was seventeen-years old. It was not until she was thirty-five in 1995 that she came back to America on a visitor's visa and, once here, she applied for political asylum that gave her the legal residence status.

Neda left Iran for the United States when she was thirteen with her family in 1985. Her family took religious asylum in Pakistan for two year before they could come to America with the help of the United Nations. Her family was part of a religious minority called Bahais. She says just like Christians, Jews and Zoroastrians, the Bahais were under severe pressure from the government and many had their properties confiscated. She explains that the regime's hostility sent her family in search of religious, political and social freedom in America. 
Parvaneh came to the United States through marriage to an Iranian man in the year 2000 at the age of twenty-five. She says that although she was only four years old when the revolution took place, she was conscious of the freedom women enjoyed in America and it contributed to her decision to come here.

Azeen came to America at the age of seventeen in 1985 through a student visa. At the age of fifteen she had been involved in the Mogahedeen group, which was an Islamic group against the regime. She served fifty days in jail for her activities and a year of home arrest. Her family decided to send her to the United States so that, as her mother told her, she could be her own person and live her own life.

Sima immigrated to the United States in the year 2000 through marriage to an Iranian man in America. He is sixteen years older than she is and she only knew him for a week. Although he had been honest about his low income in America, Sima was fed-up with the daily harassment over the hejab and had little hope for a decent future in Iran. She wanted to come to America and be able to bring her whole family here gradually.

All the above participants have one thing in common in that they have made the Unites States their home due to political, religious and social freedoms they have found here. They say they or their families have come to make a better life here not to make more money necessarily, as some have lost monetarily in the process of migration. Improved economic status could be part of the definition of a better life, but no one referred to it as the primary reason for migration. Their optimism in establishing financial security comes from their trust in American democracy. 
The following segment details the type of discriminations the participants have experienced or perceived to exist in Iran, which contributed to their decision to immigrate to the United States. All the respondents, regardless of their time of migration, decided to make the United States their home largely due to the legal and cultural patriarchy strongly imbedded in the political and social system in Iran. Participants in this study suggest that women who immigrate have experienced discrimination based on gender and have seen oppression and sexism imposed on the larger community of women; they have felt constraints imposed by family, society, and the legal system. They definitely possess gender consciousness and are defiant of gender inequalities. They and their families have exhibited agency in combating or escaping the cultural and legal patriarchy of Iran. Educational and economic opportunities have been made available to Iranian women in the United States, and they have worked hard to take advantage of these opportunities. Access to education and work has been a continuous part of their struggles. It is through more equal treatment, equal pay, and access to political participation and education that they could gain legal rights and economic independence. Their immediate exploration of such opportunities here is evidence of their quest to use education and work to achieve equality and independence. They have aggressively pursued education especially in the humanities, journalism, immigration law, and the arts and sciences, which has afforded many of them upper-middle class status socially and economically. ${ }^{146}$ The gender and political limitations of the Islamic state has contributed largely to Iranian women's consciousness of gender roles and sent some abroad in search of greater equality socially,

\footnotetext{
${ }^{146}$ Shavarini, 17.
} 
politically, legally, and economically. Cultural patriarchy is emphasized in the Muslim religion, and religion is not separate from the culture or from the current legal system in Iran. Cultural and legal discrimination against women after the revolution was most severe in the early 1980 s when most of the participants came of age in Iran. ${ }^{147}$

\section{Hejab}

$H e j a b$ means to conceal a woman's hair and body and to refrain from any activity that might sexually arouse or distract men. With such a loose definition, concealing the sexual power of women could apply to a long list of activities as the participants in this study provide multiple examples. Hejab has been an institution and an instrument of control as women are desexualized and lose opportunities of self-expression. It has restricted women's type of education, fashions, and their participation in sports and the performing arts, not to mention the hassle of maintaining the hejab through daily activities. Gender segregation is also part of the hejab, which is especially difficult to maintain. In separating the two sexes, the government attempts to control the sexual tension between men and women. Hejab and segregation, rather than protect women from the sexual desires of men, have caused inferiority, inequality and immobility for the majority of women.

Azar Nafisi, who is a professor at Johns Hopkins University, has written the \#1

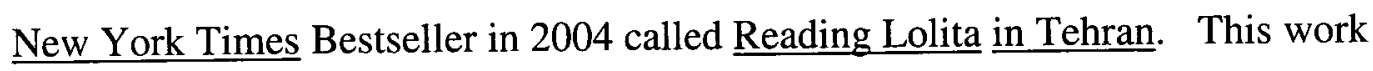
expresses an objection to the censorship of education in Iran, specifically the reading of the Western classics as she tried to teach literature at the University of Tehran. Nafisi

${ }^{147}$ Povey, 51, 55, 60, 68; Ghorashi, 70-98. 
was dismissed from her teaching position at the university for her refusal to observe the hejab. Her book is about how several of her female students who met at her home for secret readings of classic fiction, found that literature gave them the imagination to escape the "limits of reality" they experienced under the regime and provided them with a small sense of control over their "stolen lives." It afforded them a taste of truth about the nature of humanity, not the form imposed by the government. She discusses how the university was more concerned about whether women wore make up and carried contraband (western magazines and books or make up among others) in their daily searches than they were about the curriculum. ${ }^{148}$ This is what she says in her objection to the mandatory hejab: "When I wore the robe, my whole body disappeared: my arms, breasts, stomach and legs melted and disappeared and what was left was a piece of clothes the shape of my body that moved here and there, guided by some invisible force."149 Nafisi also objects to the fact that women are deprived of the smallest use of bright colors in their modest clothing and have to conform by using dark colors of black, brown or navy. ${ }^{150}$ She has been outspoken in America with her criticism of the regime's constraints on human and, specifically, women's rights. She objects to the initial decision to lower the age of marriage to nine years old (in the immediate months after the 1979 Revolution), the constant harassment of women over the observance of hejab or of their being seen with men other than their relatives, for not allowing women to leave the country without the permission of their husbands or fathers, and for trying to make

\footnotetext{
${ }^{148}$ Nafisi, 167

${ }^{149}$ Ibid., 161.

${ }^{150}$ Ibid., 4.
} 
women invisible and powerless. ${ }^{151}$ The women in this study see the hejab as an element of control over women. Neda insists that the "hejab is like a leash around the dog's neck." Afsaneh says the "hejab is not a woman's dignity; it is a woman's slavery." Faranoosh argues that the hejab inhibits women's mobility as monitoring occurs everywhere, and women are constantly scrutinized as to how much hair is hanging out of their scarf or whether they wearing make up. It is "degrading and ridiculous."

In the case of the following two participants, hejab interfered with their work, limiting their career options and making their jobs harder to perform. Sharareh says that she did not want to get married even though she was thirty-three, but it looked a lot more attractive when it came with an opportunity to go to America. She says she would have gone to any country that did not enforce the hejab, "even India." She too was tired of the daily harassment on the streets by the guards for not properly observing the hejab, but, for her in particular, observing the hejab meant she had to give up a teaching position that she had hoped to get. Accepting the teaching job, which was working with young female students, meant that she would not only be expected to uphold the hejab at work, but also that her entire personal and social life would be monitored to meet the government's standard of what a proper role model for young girls should be. That meant no makeup or showing of hair at even private social gatherings, or dancing even at indoor parties or listening to western-style music (anything about romantic love). Sharareh is now in America is pursuing a teaching career.

\footnotetext{
${ }^{151}$ The age of marriage for women was raised to 15 years in the 1990 s as the result of great pressure exerted by women from all political spectrums.
} 
Azar was a dulla (a person who helps with childbirth) at the hospital. Hejab was particularly hard to keep in her working environment as she had to cover herself from the male patients who came in and went out of the unit. "It was so hot and we had to cover ourselves in the extreme heat; we couldn't wear makeup and were searched for possessing it at work. This bothered many women." She shares an experience: "My daughters and I went to a beach we had visited several times during the Shah era, but after the revolution we were so afraid of being arrested and go to jail for not wearing socks and covering our feet in the sand. It was not fun. All we felt was fear, lots of fear. It is hard to observe the hejab even for the women who have been brought up under this regime. I did not want to subject my daughters to that life. The young girls especially who see women on internet and satellite shows without the hejab are often resisting it."

Mina was educated and trained by American Bell Company, and she managed twenty people at the phone company during the Shah's regime. She said she was independent socially and economically before the revolution in Tehran. "I was punished after the revolution for what I had done before the revolution such as dressing in the western fashion, revealing my legs in short skirts which was legal at the time. My punishment included dismissal from my work. My own immediate coworkers and managers reported me to the government for being too western before the revolution. It was called the cleansing process where they cleared companies of people who held western values, which in this case meant not upholding the hejab." Mina also thought of rescuing her two girls from such treatment. She is a single mom whose daughters were twelve and thirteen when she decided to leave Iran. She and her daughters were harassed 
for occasionally showing some hair and were detained for short periods of time in the first two years after the revolution.

Fari shares a memory of being in Iran when she was thirteen. The memory reflects the regime's social patriarchy and use of hejab as an element of control against women mobility, even at a small level. "I remember going out for a sandwich with my girlfriends after school and the principal saw me. She complained to my mother that going out to eat with other girls was loose behavior, behavior like a prostitute." Fari remembers all the women in her family hated the mandatory hejab even more than she did. She was harassed often by the very same people who only months earlier before the revolution, had been open to women wearing short skirts and revealing their hair. She says these people did not care about observing the hejab. They just wanted to partake of new power. Girls as young as nine years old had to cover their hair. Her mom, who was not particularly religious and often had big gatherings at her house with plenty of dancing and drinking, had to cover her hair and could not have such parties with the restriction on music and dancing and the segregation the sexes.

On hejab, Zahra says that what one chooses to wear should be a freedom of selfexpression. The government should not force any dress code on people. "I am totally against the hejab for myself and in public schools for girls. If adults choose to wear $h e j a b$, it is their decision, but I am against forcing girls to wear it before they reach adulthood. It is gender discrimination at a young age."

The subject of the hejab proved to be the most upsetting issue to the group of respondents in this study. The reasons for dislike of the practice varied from its 
discomfort and inconvenience, the negative impact it had on job performance, to the fact that was an element of control over their bodies and their lives and took away their freedom of expression. Neda characterized as a dog's leash, and Afsaneh called it "slavery" These two ladies were probably the most virulent in their hatred of hejab, although none of the respondents favored the practice and none have ever considered maintaining the hejab in this country. Six of the women cited the hejab as an important factor in their decision to leave Iran: Mina, Fara, Azar, Sharareh, Faranoosh, and Sima.

\section{Discrimination against Women in the Media}

Ziba Mir-Hosseini, who is a freelance anthropologist, researcher and filmmaker and a research associate at the Center for Near and Middle Eastern Studies in London, writes that in the late nineteenth century with modernization and the advent of photography, women's role in the media began to take a more realistic form. Under Reza Shah, the push for modernization took place at the very time that filmmaking was taking off as a medium of entertainment in Iran. Under the Shah, as the status of women changed and their role became more public, women participated as an integral element of the burgeoning film industry. The cinema gave a new public presence to women.

Women and love stories became fundamental to film making in the twentieth century. After the 1979 Revolution, however, various political factions tried to define conservatism through women. In film, this meant restrictions romantic roles for women, which left little room to display social realities such as gender relations. The Islamic Republic tried to control the cinema and subject it to the state's ideology. The imposition of hejab and sexual segregation further restricted women's self-expression in the media. 
As long as religion dominates politics in Iran, the art of filmmaking cannot be free from conservative ideologies. Iranian filmmakers, nevertheless, have been active in protesting fegh (Islamic jurisprudence) which initially imposed many restrictions on the portrayal of women in film. Liberal segments of the government have assisted the filmmakers in confronting cultural conservatives and, more and more, the filmmakers have achieved concessions from the fegh. For example, from the total absence of women in Iranian film in the 1980s, Mohsen Makhmalbaf, in 1991, produced the film A Time to Love, which told the story of a love triangle, certainly a forbidden topic of film in previous years. Also, one should note that female film directors in the early 1990 s produced films dealing with female characters and love, such as the film Nargess by Rakhshan BaniEtemad. In 1998, Tahmineh Milani's Two Women and Bani-Etemad's Lady of May definitively brought back to Iranian cinema the subjects of women and love. Iranian films, since this rehabilitation, have achieved international fame and have become a bridge between the Iranians abroad and those in the homeland. ${ }^{152}$

The respondents in the within study tend to mentioned problems in post-1979 Iran both of women trying to establish careers as performers, as well as the restrictions on the public presence of women in both society and in the media.

Mina, for example, explains: "I wanted to be a singer and had some training, but the revolution put an end to this dream as women are not allowed to sing publicly."

Azar expresses her feelings of sadness at the absence of women on the media: "It was depressing not to see women on TV. Since the women didn't have hejab in the

\footnotetext{
${ }^{152}$ Ziba Mir-Hosseini, "Iranian Cinema: Art, Society and the State," Middle East Report 219, ( Summer 2001): 26-29.
} 
foreign movies, they would black out their faces. It seemed that we as women were erased

Faranak had learned Persian dancing in pre-1979 Iran when she was a young girl. Here in America, after she had obtained a B.S. in Psychology, she decided to make a career teaching Iranian dance to young Iranian girls. She wants to help to preserve the Iranian tradition as well as bring the Iranian community together here. She states: "I enjoy what I am doing since I get to express my passion and have a successful career. This career would not have been possible in Iran since it is forbidden for women to dance, especially in public."

Faranoosh pointed out that "you don't see many women in the media freely expressing themselves and their grievances. Aside from being barred from certain roles, they also have to adhere to the hejab which is even further limiting to their art of filmmaking." She also shared a memory about a female friend who is an actress in Iran. The friend said that for a female actress in Iran to "make it through movies and acting opportunities, she has to provide sexual favors often." It was "even worse than Hollywood." It is ironic that the Islamic government has a strict policy on women's bodies being protected by covering them but does not protect women against sexual harassment when female actresses such as her friend are often solicited to provide sexual favors in exchange for acting opportunities.

Zahra picked up on the aspect of women have the ability to express their own views and opinions through the media. She said: "In Iran women have done a great job publishing newspapers and magazines such as “Zanan” to address women's issues. 
Unfortunately, the government keeps closing their offices and stopping their publications. Because of the important role the media plays in forming our perceptions, it is crucial for the women who believe in women's equal rights to influence the media to reflect their views."

\section{Political Repression}

During the first two years of the revolution, there was somewhat of an open environment for political activities of various groups, but afterwards the regime imposed its power forcefully by banning all political opposition. For many young idealists who were involved in different leftist and Mogahadeen groups, it came as a devastating shock that overnight they were subjected to imprisonment, torture, and death for their political activities. For some participants political repression in Iran had a direct impact their personal and professional lives. They were harassed and imprisoned for their political participation, but serving the prison sentence was not an end to their punishment. The social consequences that followed made forming a new life almost impossible.

Mojghan served a three-year prison term for participating in a leftist organization. After she was freed she was unable to establish a career. She was treated as "a secondrate citizen" for having engaged in political activities against the regime. Two years after she was released, she was still denied access to public university. She had been released on the condition that her father would give the deed of his house to the government for two years, which turned into five. In that period he could not sell the house or borrow against it. This was particularly difficult for her father who, as a building contractor, relied on loans. Her father and her brother-in-law were made accountable for her 
behavior, should she come to be involved in any political activities after her release. Their passports were confiscated and they were not allowed to leave the country. Meanwhile the brother-in-law had to leave the country for Europe for his job, and the government put his wife in jail for forty days even though she had two young boys. This imprisonment went on her record and for years she had trouble landing a job, especially government work. "It was so painful for me to see that I have troubled my family to such extent. In other words, having some limitations in America as an immigrant is still better than having legal and social limitations in Iran."

Azeen was only fourteen during the short period following the revolution that provided some political freedom. She sympathized with the Mogahadeen group, an Islamic sect critical of the new regime for its non-secular and non-democratic orientation. She mainly helped out with the poor. When the regime suddenly decided to clamp down on all opposition groups, it showed little concern for the age of the participants in these groups. Azeen's family pulled her away from her active friends for a period of two years out of fear for her safety. A friend of Azeen, who was two years older than she was and was still active in the Mogahadeen, borrowed a small amount of money from Azeen. Shortly after this incident, Azeen was arrested on charges of providing financial support to the enemy of the regime. Azeen says "I defended myself against the guard who was constantly threatening me from behind a curtain with two holes cut out for his eyes. Without telling me what the charges were, he kept accusing me of not cooperating for not mentioning any other members' names and activities. I finally told him that if he is referring to the small change I had loaned a friend, I would be happy to confront that 
friend to explain that the money given to her was for her personal needs and not in support of the Mogahadeen. He told me that we would have to do this at her graveside since she had been sentenced to death at the age of eighteen. I had never been more frightened." Azeen was kept in jail for fifty days without any visitation rights nor were her parents given any information about her, even as to whether she was alive or dead. She says she knew the regime had killed children as young as fifteen to establish legitimacy through fear. The regime would display on television young captured students from different political sects whom they had arrested. They forced them to say that they regretted any political opposition to the new regime. After Azeen was released, she was put under house arrest for one year and could not attend school to finish her last year in high school. It was during these fifty days that her parents decided to send her out of country. She could not get out during the first year after her imprisonment because she had to report to a government office every day and sign a form that she was not participating in any political activity. They also held the deed of her parents' home as ransom. When the year was over, her parents applied for German visas for all three of them. Azeen took a domestic flight to Tehran for the German embassy. Her plane was hijacked by a man and a woman who happened to sit next to her. It was diverted to Iraq which at the time was at war with Iran. In Iraq the passengers were solicited to get political asylum by the Iraqis so it would be good international publicity for them. The Red Cross, however, convinced the passengers that this process would be difficult and often impossible and that they might spend years in a camp under uncomfortable conditions before any possibility of asylum. Azeen claimed that, in the meantime, the 
Iranian government proved it cared only about its expensive plane that had fallen into the hands of the enemy. The Iranian government kept demanding the return of the plane. After a week, Azeen said, with the exception of one passenger who did apply for an asylum, the rest were returned to Iran. Upon arrival, the guards took them directly to Eveen, which is a prison facility for the most serious political activists. Azeen was only seventeen, and she was sure, considering her political history and the fact that the hijackers were sitting next to her on the plane, that this time they would kill her. When she was released the next day after hours of interrogation, her parents took her with them onto a plane going to Germany without notifying anyone in their families or saying goodbye. They spent three months in Germany and three months in Turkey before they were granted visas for the United States.

Afsaneh says that "under Shah's regime we had some social, economic and religious freedoms, however, we had no political freedom and that is what caused the 1979 revolution." Her sister was arrested post-1979 and imprisoned for a while for her political activities at the University of Tehran. She committed suicide to protest the present regime by burning herself.

Azar had no political affiliation but she shared a story about her neighbor. "I remember one day that my neighbor was crying, not just a sad cry but a cry out of severe heartache. When I asked her why she was crying, she told me that her daughter was arrested for possessing anti-regime books and magazines and was killed within two days of her arrest. I was so frightened even though I had no political activities. Fear was all around me and that made life unbearable." 
These respondents all describe severe political repression by the government of the Islamic Republic. In Azeen's case, the threat of political and legal repercussions led directly to the decision of her family to leave Iran. In the other cases, the women did not leave under the threat of arrest, but each could report about persecution against someone they knew personally. Mojghan herself had suffered imprisonment for three years because of her political activities and her sister-in-law was then targeted by the regime and jailed as a form of harassment towards Mojghan and her family. Afsaneh's sister was imprisoned and committed suicide by setting fire to herself in protest against the government. The 18-year-old daughter of Azar's neighbor was arrested and executed within a two-day period. Next to the hejab, political repression appears to be the greatest complaint of the respondents concerning the situation in Iran and a chief reason for their desire not to return there.

\section{Religious Freedom}

After the revolution, some participants experienced religious discrimination that led to their decision to migrate. Neda recalled, "My family immigrated to the United States due to the regime's religious intolerance of the Bahais. My father was harassed due to his religious beliefs. My cousin was sentenced to death only due to being a Baha'i and his children were expelled from school. My aunt who was an educated woman with a high profile job before the revolution was fired from her job along with twenty other Baha'i employees." Neda gave religious freedom as the main reason for her family's decision to leave Iran. Faranak's family was Muslim, but, she said, "We never practiced. 
We considered ourselves a more modern family." She added that her family came to America "definitely ... for the political and religious freedoms."

Although she did not emigrate from Iran as a direct result of persecution of her religious minority group, Parvaneh did advert to repressive measures related to religious issues that influenced her decision to come to America, in particular, the imposition of the hejab. Parvaneh is an Assyrian, a Christian minority group active in Iran and in several of the surrounding countries such as Iraq, and Lebanon. She notes that the Islamic laws after the revolution have decreased women's legal and civil rights and have forced the hejab on all women regardless of their religious or secular beliefs. She left Iran in 2000 to marry an Iranian man here in America. She did this because she knew there was "more freedom and opportunity" in America.

Other women also closely identified the hejab with religious repression. For example, Mina decided to move to the United States so that her daughters could have "better lives and have more freedom to do and wear whatever they wanted, and to have a better education free of religious requirement." Sima commented that she always wanted to come to the United States because she was harassed for not upholding the hejab properly: Once the authorities arrested her for her hejab and called her family to shame them for raising a daughter who was not a proper Muslim. Her family stood up to the guards and said it was none of their business what kind of Muslim their daughter was and it was up to their daughter what she wants to do with her life. She noted that parents "prayed and were Muslims," but "never asked us to practice Islam. They didn't like how the regime was using Islam to suppress freedom." In an adverse comment on control by 
the Islamic religious establishment, Sima noted with obvious disapproval not only that college students were required to study Islam as one of their classes, but also that their instructor, a cleric, tried to extort sexual favors from the girls for passing grades.

\section{School Discrimination}

Education has been another crucial area where women in Iran have fought to gain equal access in all fields of study. In the immediate years after the revolution, the government provided access to domestic types of education such as sewing, cooking, and homemaking. After the revolution, women were still allowed into medical schools, specifically to study obstetrics, gynecology, pediatrics, dentistry, and family medicine, but much discrimination against women in education was evident. Sharareh notes:

There were two options for college. Either you could go to government schools that were practically free or you could go to private schools that were too expensive for the middle class families such as mine. If a family had enough money for private school, they would often put their sons in school. On the other hand, the free government schools had so many applicants that many would be rejected. Furthermore preferences on accepting students and financial aid went to families of the victims of the Iran-Iraq war and help with their tuition. In my state at that time, which is not as developed as Tehran, three fields were offered, agriculture which was reserved for male students only, nursing reserved for women only and English and Farsi language which either sex could pursue. I would hear how optimism among the female students was low for thinking that once they finished school the few available jobs would be given to the male graduates. There is always this assumption in society that men are the head of the family and should have the priority to get the jobs.

Parvaneh says that although she thinks more women are educated than ever in Iran, they still have less freedom to be mobile and social. The women, who have jobs, are paid less than the men. Zahra says some of the jobs have been reserved for men only. For example, the judiciary and presidency are for men only. "A woman cannot become the 
president and that is why some people call the presidential election in Iran illegitimate because half of the population can not participate in it." Even though the percentage of women with higher degrees is larger than that of men, managerial work and higher paid jobs are normally reserved for men. Faranoosh studied electrical engineering and she believes that if she went back to Iran she would not be given a job since that is a maledominated field. She says this gives men more financial control over women. She also says women at best have two choices: either get an education or get married young. For those who finish school, there is always the risk of not landing a job. Some of them regret investing their time in education. Those who did not go to school and invested in their beauty with plastic surgery, feel entitled to a have a wealthy husband support them.

Faranoosh asserts that men in Iran are promiscuous. They can have a temporary marriage, which is like prostitution. They can have several wives whom they can not financially support. Some women have taken on prostitution to support themselves because of the high cost of living.

\section{Discrimination in Women's Sports}

Iranian women have faced many restrictions in their efforts to participate in professional sports, especially since the revolution, adding to their struggles for further social acceptance in competitive sports. The limitations imposed by the government only slowed down the process of social acceptance. After the revolution, the government limited the types of women's competitive sports with arguments about needing to maintain the hejab. Many women actively resisted the government's attempts to shut down women's sports. 
Mojghan shares her experience with the women's sports program and points out that, although they have been able to participate in some sports, such as archery, Iranian women, nevertheless, still have a long journey ahead of them in being able to participate in all sports at the national or international level. For a few months after the revolution, women had no place to exercise. Women could not work out with men in the same gym. Despite much pressure from the government for women to give up sports entirely, women found a way to go around the new segregation measures and pushed the government to allocate a stadium for them, named Taj (meaning crown), and it was a modern new stadium that had catered to the royal family during the era of the Shah. When it became a place for women to exercise, the government changed the street name where the stadium was located to Hejab. They covered the pool, had two male guards stopping any men at the entrance, and in the front, installed a curtain behind the door to maximize concealment of any women inside. A female employee of the government continuously checked membership cards. Women were allowed to participate in bodybuilding, light gymnastics, volleyball, basketball, handball, track and field, badminton, table tennis, swimming, and diving. Mojghan says, prior to the revolution, women had participated and competed in all sports, and the 1974 Asian Olympic Games were held in Tehran. Women across the country have continued to participate and compete in athletic events and have formed sports leagues. In 1999, they participated in the first international sports competition despite much resistance from the fundamental clerics. They have a long way to go in achieving some of their basic rights and since the revolution their freedoms have been threatened by the authorities of the regime. 


\section{Cultural Patriarchy}

Cultural patriarchy has been present in Iranian culture prior to the present regime.

The Muslim religion has been part of Iranian history for almost 1,400 years. Islam cannot be separated from the culture as it has contributed to this patriarchy, especially since theocracy controls the legal system in Iran. One of the older participants, Afsaneh, who recalls the Shah's era, describes her experience. She was financially independent when she worked for the Iranian National Oil Company (AIOC). She says:

As a girl growing up in an Islamic country I felt my future's potential as a woman would be limited. I did not want to follow in the footstep of the women around me. I wanted a different life not possible in Tehran. I thought I could live my life as I pleased in America. While in Iran I had to live my life for my parents, grandparents, neighbors, cousins, and everyone around. I could not understand why boys could do everything they wished and we as girls were constantly watched and were not able to participate in sports or social activities. I also did not care about having to live with my parents until I was married even though I was financially quite independent. I came to U.S. to study electrical engineering. However, I never had the desire to return to Iran.

In 1975, while she was working for Hughes Aircraft company satellite division, she was hired by the government of Iran to go back and head their satellite department at the Iranian Telecommunication Corporation. At a luncheon at Hughes Aircraft Company, one of her colleagues told her that he did not think she would be able to tolerate being in Iran beyond eight weeks. She returned in seven. Afsaneh says, "I always say the first best thing I ever did in my life so far is when I left Iran in 1964 and the second best thing I did was to leave Iran in 1975." She says that after seven weeks in Tehran, she could foresee a bloody revolution in five years. She told her entire family to sell whatever they had and leave Iran. They never did and regretted it ever since. "The 1979 revolution, I 
believe, took the modern Iranian women back by centuries at the same time brought the traditional women out of their home prison and exposed them to modernity. Women lost all their rights under the Islamic Republic and went back to their more than a century old status of a second rate citizen in Iran." She says, many women lost their jobs and many professions were denied to women. Women also lost their right to social and economic mobility due to the Islamic laws which force a "woman back to the dark corners of home and society."

\section{Patriarchy in Marriage}

Patriarchy is so deeply embedded in the character of all Iranians as women too have been conditioned to believe that their priority should be motherhood and domesticity. As contemporary Iranian women have expanded their sphere beyond traditional roles, men have shown slower receptivity to such changes, for fear of loss of control and identity. Even Iranian men, who have spent decades away from Iran, have done little to change their patriarchal behavior as noted above in the study done by Hojat. The study showed that Iranian women take on egalitarian practices and values in America faster than Iranian men, and the responses of the following participants furthermore confirm this. Their responses reveal a consciousness of gender and legal rights for women in America that has given them more power in relationships even with Iranian men. On the questionnaire that they were given, the participants were most passionate on the subject of Iranian men, and they revealed much about their relationships and their perception of the marital status. They all had experienced some form of patriarchy in 
their romantic involvement with Iranian men. The participants who were married to nonIranian men expressed the more positive comments about their spouses.

Fari married an Iranian man with whom she is pleased. She does not have major complaints beyond the fact that he does not celebrate her birthday or Valentine's Day to make her feel special. She does the majority of the domestic chores, and he helps at times and is nice to her family. Fari is grateful to him for providing for the family even though she too works, as a hair stylist. Fari several times reiterated that she got really lucky to find such an Iranian man, implying that other Iranian men are more patriarchal in their treatment of their wives.

Neda also married to an Iranian man and has two children. She often complains about his large ego for not wanting to involve himself in any house work or in the raising of their two children. He goes to extremes in his attention to the behavior of the children. Either he is passive towards them or is occasionally authoritarian and yells at them. She thinks not just her husband but all Iranian men should become more respectful of their wives' hard work, whether it is housework or professional work. "I believe moms have one of the most important jobs in the world and that is to raise kids. Iranian men here have no choice but to acknowledge the laws that were set by the women's movement in this country. Iranian men in Iran don't have to follow any laws regarding women's rights so they just live their lives based on what they have learned in society. Women are not sitting around in either country. They are rebelling and letting their voices be heard and fighting patriarchy." 
Mina says, "Iranian men don't deeply care about you; they are deceiving. They expect more domesticity of Iranian women than they do from American women. I was dating an Iranian professor here for twelve years who secretly had a relationship with his ex-wife. Iranian men have good manners and pay for dinner which is nice but I don't let them have anything on me, so I always return the favor by making them dinner. American men expect you to pay for yourself even on a date."

Azar, whose husband is American, says, "My husband who also teaches ballroom dancing says that with me our house feels like heaven. He appreciates me and likes Iranians for being so kind and hospitable." She says that American men value woman's legal rights and freedoms more than Iranian men do. Iranian men insist that Iranian women be domestic. The difference between Iranian men versus American men, she claims, is as drastic as the difference between "black and white." Iranian men are family-oriented and are more responsible toward their first family, such as their parents, but American husbands are more committed to their wives first. During the regime of the Shah, she recalls, there were very few divorces; the cultural expectations did not allow for the woman to leave even though there were plenty of arranged marriages. Men were in charge of divorcing the women. If ever a case arose of a woman divorcing a man, she could not collect the mehriah (which is the amount of money or other valuables given to the woman in case of a divorce). If a man divorced a woman he would find a way to get out of paying her the mehriah. So divorce was not a good option for women, and women grew tolerant of almost any situation to avoid being divorced. In America, she noted, women have considerable legal rights, even more than women did in Iran during the 
Shah. Women know they have options in the U.S. "I took notice of this during my visits to the U.S. before the revolution." Beyond just the hejab, in Iran, Azar explains, one succumbs to the patriarchal teachings in the culture and religion due to social pressures even if one is not religious. "For example during the Shah we had parties with dancing and no hejab; now the government doesn't allow for dance music at parties, but it's often the neighbors who report you."

Sharareh says, "My Iranian husband has lived in the United States for the past twenty years, but I think even if Iranian men live here for a hundred years they will never change their ways. They are controlling of their wives and the finances. This is not to say that Iranian women allow them. Iranian women in the United States show more control in their relationship since they see the freedoms and choices they have here."

Sara is married to an Iranian man living in America who brought her here. Sara thinks that Iranian men can be good providers and protective of their families but at the same time they expect domesticity from their wives. "Even though I work at the bank and contribute to our finances, I am expected to take care of our two children and do all the house chores. I think American men are easy going and are fair in treating their wives."

Zahra says that her expectation of Iranian men, in America or in Iran, is that they should not lie about how liberal they are. "If they claim to be liberal or open-minded then they should change their cultural learning toward treating women. They should see them as equals and treat them as such in all aspects including sexuality. Unless Iranian men shed their sexist cultural learning, it doesn't matter where they live in the U.S. or 
Iran. They end up treating women the same. Most American men, but not all of them, who have been exposed to the changes wrought through the women's liberation movement brought to the U.S., treat women as equals. This is especially obvious in sexuality. For example they are not expecting their date to be a virgin."

Zahra says,

My relationship with my spouse who is not Iranian has been that of [an] equal partners rather than master and slave as it is often the case in Iranian marriages in Iran. My expectation of Iranian men is to grow up and back the Iranian women in their plight for freedom and equality. American and European men are more responsive to the needs of their wives, while Iranian men are good at ordering their wives and daughters around. Western men believe in equality of sexes; at least they try, while Iranian men are spoiled, dictatorial, and indifferent to the needs of their women. Patriarchy is alive and well in the Iranian community both here and in Iran, especially with older generation. However, I believe the younger generation of Iranian men is more open to the needs of their women.

According to Faranoosh, "Iranian men judge women simply based on appearances. They chase the prettier women and once married they try to control them." She says Iranian men treat Iranian women worse than they would American women. They expect Iranian women to perform domestic chores and to be traditional in that the wife should not have a social life of her own without their husbands or go places without them. She complains that her husband who has been in the U.S. for twenty-six years and came here at the age of fourteen has not changed his traditional expectations and is not any different from the men in Iran. She claims that Iranian men in America just pretend to be different because it is politically correct. "I think American men give their wives a lot more freedom. They are not so controlling. They share in the housework and respect that the woman is an individual too not just the wife. But in general, there are more 
freedoms for women in America. As far as I can see women can do whatever they want here." Faranoosh says some Iranian men who don't care for the liberated Iranian women in America go to Iran and get the youngest and prettiest girls as their wives and bring them here. But those women are only using the men to get to freedom and as soon as they can, they become independent and no longer tolerate the way the husbands want to control them. She says some of these women are materialistic and overspend in access to the new consumer goods and put financial pressure on the husbands. Meanwhile, the men had hoped for a traditional Iranian home life. The difference in expectations and often age differences leads to a high divorce rate in these marriages.

These respondents all reveal consciousness of gender inequality prevalent in many marriages, whether or not suffering from such a situation in their own lives. Westerners, including Americans, might find surprising the entrenched attitude of Iranian men towards patriarchy in their marriages, given the number of years these men now have lived outside of Iran and Islamic cultural dominance. The clarity with which these women enunciate the issue underscores the growing sense of empowerment among Iranian women.

\section{Perceptions of Discrimination in Iran}

The dismay with life in Iran expressed by many of the participants may represent perceptions that have exaggerated the negative aspects of the legal and cultural system in Iran. An objective examination might show that the restraints are actually less onerous than claimed by these immigrant women. They do not acknowledge the many positive changes discussed above by Iranian women and some liberal segments of the 
government, and they are more attuned to instances of discriminations through true or fictitious stories. Thus, Sharareh concludes, "In Iran it's very hard for women to control or change their legal and cultural restrictions, the government and people don't allow for it." This negative perception plus the longevity of the current regime has contributed to the decision of the participants to consider the United States as their permanent residence.

Neda observes that Iranian women after the Revolution have been forced to wear the veil once more and are prevented from holding political and high profile jobs. They are banned from taking a seat in the senate or becoming judges. Socially they have a very hard time if they decide to leave a marriage due to any circumstances. They do not have the right to leave the country nor to have custody of their children in a divorce even if the husband is not capable of caring for the children. Her comments, however, do not acknowledge some successes in recent years of the movement for equal rights. So, although Neda points out that there are more women enrolled in the universities than ever and they now have more working mothers than before, she points a negative spin on the information and concludes only that "the true social and cultural freedom and rights are still not there." Still, her perception contributes to her decision to stay in the United States permanently.

Examples of negative evaluations of the post 1979 regime are legion. Fari gives an example of her perception of women's lack of property rights in Iran, explaining that if a woman in Iran becomes widowed and her husband had owned an orchard, she could not inherit the property. She would be permitted to inherit the trees on the property, but only a son or a male relative of the husband could receive the property. Fari gave 
another example of lack of child-protection laws and the helplessness of mothers in this regard. She says an eight-year-old boy had his hand crushed as it was placed under the wheel of a moving car as a form of punishment for stealing. This was done by the regime's guards to show that there is no tolerance for stealing. She gave another example of a friend in Iran who lost the custody of her children to her husband in a divorce as it is often the case. She felt deceived by the new regime because many promises of freedom, independence, and an improved economic situation were not fulfilled.

Mina says "My supervisors and upper management had urged us to go to the streets and protest the Shah's regime for suppressing freedom and killing the defiant youth. Although I didn't have any political or religious affiliation, I felt obliged to listen to their orders and partake in the protests... after the revolution I saw many freedoms disappear especially for women." She adds, "I plus many others felt deceived as the new regime didn't deliver on its promises of the revolution for more freedom."

Zahra gives examples of the difficulties women face in renting apartments alone or checking in hotel rooms alone. She also mentions that women increasingly are resorting to prostitution to offset the high cost of living in Iran. She believes that women's civil and legal rights were altered heavily after the revolution, and she refers to the many issues of discrimination in family law: women do not have the ability to institute divorce cases nor to obtain custody of their children; the share of an inheritance for a man is twice as much as that for a woman.

The point in noting all these cases, however, is to stress that the perception may or may not accord with objective reality. One must be careful not to reach overly negative 
conclusions about Iranian society too quickly based just on the reports of respondents.

\section{Religious and Political Background of the Respondents}

The study participants clearly distance themselves not just from the government but from Islam, which they see synonymous with the regime. None of them said that they are practicing Muslims, but almost all emphasized that they and their families are liberal and modern. Research done by Mohsen Mobasher, which will be discussed later in this study, confirms this point. Mojghan says, "As far as my family background goes, my mother has a general desire for justice and equality, but my father was very hopeful in the revolution especially in the few years of post revolution." As for the rest of her family, she says,

All my siblings were also leftist in the early years after the revolution but now consider themselves liberals and want justice and equality in society. I too have moved to the center and consider myself a liberal. My family, I would say, leaned more towards a liberal standing especially the way my parents gave us the freedom to hold whatever political beliefs we wanted, and didn't push us into any traditional way of life. For example, my sister who is now fifty-six has never been married and has not been pressured by my parents to do so either. Another example of their supportive and liberal way is that they let me become an exchange student in the U.S. in 1975.

Sharareh reports,

My family practiced Islam, but by no means were they fanatics or fundamentalists. They did pray and my mom always covered her hair and was modest even before the Islamic revolution but she never forced my sister and me to dress in any particular way. We were trusted and free to choose what we wanted to wear. Even though it's customary to have young girls marry shortly after high school and most likely after college and there were plenty of relatives who kept asking me, when are you going to get married?, my family never pressured me into marriage. I also have two older brothers who were not controlling me or my younger sister in telling us how to be more careful with our $h e j a b$ or pray or any other religious practices. 
Fari also describes her family as liberal: "My family was pretty open and liberal and had no political affiliation to the leftists or religious organizations. They lived in central Tehran, the capital where the revolutionary movement was all around them, and they got swept into it. They never thought the revolution would mean the loss of freedoms for women otherwise many women I knew would not have participated." Afsaneh likewise comments on the non-fundamentalist character of her family:

I was born to a middle class family. My father was a businessman and mother was a housewife. ... My father and most of his family were not religious at all. However, he did follow some Shi'a religious rituals such as giving alms on Eid Fetr, sacrificing sheep, cooking and distributing sholezard (rice pudding). Our father was very much in favor of our education. He felt that as women we needed to have a profession so we could stand on our own two feet without any need for a male provider. That is why my sister went into medicine and I into engineering. The only religious education we received was what we were taught at school, mostly Islamic Sharia. Our family was very political, anti Shah. We considered ourselves a modern family.

Faranoosh also recounts that her family was a modern one: "My family was not traditional by any means. They were, especially my dad, very nationalistic, not leftist or religious, just one of the believers in Mossadagh ideologies of democracy and was against the Shah." Finally, Zahra says that although her mother was illiterate and her father only had a sixth grade education, she considers them "modern." Her parents were Muslims but were not practicing nor were they political.

\section{Immigration for Reasons other than Economic Opportunity}

This study confirms the argument that Iranian women immigrated to the United States for political, religious, and social freedom. The following responses show that economic improvement played a lesser role and, in the cases of some participants, not 
only did immigration to America fail to improve their economic status, but also they had to make financial sacrifices to come here. Azar adverts to the comparative wealth of her family prior to emigration from Iran.

If it hadn't been for the revolution I would have never come to stay. I would just visit the United States. .. I I mainly came for personal freedom and to provide a free and secure future for my children.... Financially we were very independent with several properties that we just left behind My daughter and I went back to Iran once after the revolution and saw that some people had taken over four of our villas by the Caspian Sea. When we reported them to the government, we realized it was really the government that had confiscated our property as they resented all the people who left Iran and labeled them as pro-Shah or western, and they legitimized their confiscation by saying that it was their job to provide for the poor and that the poor needed these homes more than us. I know that this had happened to many others who left the country, some who had left out of panic and fear of the new regime.

In America, Mina has to settle for making her living out of doing nails, but she is willing to tolerate this relative state of poverty for the sake of being free. "I sacrificed my financial comfort in Iran for life in America for this very reason (freedom). I am glad that I came for now I have two educated, strong and independent girls who make me very proud. I worry about my financial future as I now have to take care of my mother who suffers from multiple sclerosis. I am suffering from many financial difficulties, but like other Iranian women I think we are all hard working and loyal in relationships and in life."

Mojghan says, "I tend to think that I would have had quite the same level of economic prosperity, had I not immigrated to the United States as far as the opportunities go. Back in Iran I was successful despite many of the government restrictions placed on me. I was a home tutor, translator, seamstress and women's sports administrator." 
Sharareh says, "I was financially independent. I had received my baccalaureate in English and had two job offers - one as a teacher and the other in the post office. I chose to work in the post office where my father was a supervisor."

Parvaneh says she has not improved her economic status by coming here. She makes the same level of income as a middle class American as she did in Iran.

In all these cases the respondent in this study demonstrate their priorities did not lie in advancing their economic fortunes.

\section{Women's Resilience in Iran}

The participants' activism, rebelliousness, and creativity in manipulating and defying the legal and cultural patriarchy suggest that their migration was not an escape from Iran but rather a rejection of gender inequality and oppression. Some participants proudly describe their response to the political and social constraints and point out the efforts of others. Mojghan, an ex-political prisoner, worked around the obstacles of job discrimination by becoming a home tutor, translator, seamstress, and women's sports administrator. She proudly points out that women outnumber men in universities in Iran even though "religious fundamentalists put a halt to that (modernism)." Mojghan insists that women are continuously "fighting tooth and nail for their rights" - even women who believed in the revolution and were supportive of the regime in the early years. Once these women lost trust and did not see the expected results, she says, they began to work in a more cohesive effort with other women groups from different ideological beliefs, including those who are religious and have ties to the government. Notwithstanding their inclusive mindset, they still suffer from arrests and imprisonment. 
Sharareh, at age thirty-three, has had no intention of getting married. She was well aware of divorce and child custody discrimination against women in Iran. In her visit to Iran, she noticed that other women too were avoiding the legal limitations that come with marriage and parenthood by either avoiding marriage or by postponing marriage while establishing some level of economic independence through education.

She says women are having fewer children or none at all.

Many of them don't want to marry at all maybe because they know how hard it is to get a divorce. I know they are always trying whether they're in the parliament fighting the laws or on the streets fighting the enforced hejab to gain more freedom. When young women are pushing their scarf back to show their colored hair or when they wear makeup or tight clothing, they are defying the regime. The girls go on the street in groups so if they get harassed for their improper $h e j a b$, they could fight the guards easier as they argue back and make a scene to get the public support.

Fari points out that "young people are fighting the hejab in various ways by wearing a smaller scarf that shows more hair, wearing more makeup, wearing tighter and shorter montoe (a loose cover like a long coat that covers the arms and almost the entire body down to the ankles). The young girls who are defiant get harassed by the male and female government guards. When many of them are asked by the guards why have you worn makeup or tight clothes, often their response is that it should be their choice not the government's business to dictate their attire."

From her own experience, Simi talks about her family's support for fighting the hejab. "Once I was detained and taken to jail overnight for not observing the proper form of the hejab on the street. My family was phoned to come and sign a guarantee that they would not let their daughter do this again. They tried to shame my family for not 
teaching me to be a better Muslim. My dad told them that his daughter had the freedom to do what she wanted. The guard realized that this time he didn't have the support of the family to force the unpopular hejab." Fari uses Shirin Ebadi as an example for defiance by saying that Ebadi is fighting obstacles and discrimination placed in the way of women's financial empowerment and independence.

Zahra, who is an organizer for an Iranian women's group in the United States, avers that Iranian women are definitely fighting all forms of oppression in Iran and abroad. She says that there are some women activists who believe their fight in Iran is indeed effective, so they continue their struggle in any form with all the hardship and risks. Among the activist women in Iran are Simin Behbahany, the dominant poet, and Nooshin Ahmadi Khorasany, a journalist.

\section{Perceptions of the United States}

The common perception of all participants expressed here is that the United States is a free land that gives optimism and hope. It is a country where women are equal to men in the eyes of the law and to a large extent society. Women are allowed to pursue their goals free from traditional expectations, and individualism is encouraged. The fact that individualism is valued in America has allowed them to credit themselves for their accomplishments and believe in their discipline. More importantly, they believe that they too can be valued and have the same rights and freedoms regardless of their ethnicity or history of conflict with the United States. Even prior to their immigration to the United States with all the anti-western sentiments they had heard plus years of government propaganda, they knew they would be treated well here and preferred life in America. 
Neda says, "My expectation of the United States was to be able to use my resources just like men and get the highest level of education to gain power and knowledge. I have certainly been brought up more openly (here) than I would have been in Iran. I am a very social and free-spirited woman, and I was able to be myself, at least around the non-Iranian crowd. In America I have had the freedom to travel, be educated and social with no one questioning me."

Afsaneh has been here for decades and has appreciated the evolution of women's rights in America. She says that in America, she was able to complete her engineering degree and become the president of her company with the confidence and appreciation of people around her. She states:

I believe I could have never achieved as much as I have in the U.S. if I had remained in Iran. The EEOC, or equal employment opportunities helped quite a bit following my graduation as an engineer. Almost every company had no place for female engineers. In early seventies women were supposed to go into software engineering only. I was the first female to graduate from Cal State Northridge in electrical engineering. I now am involved in the community politics, write editorials for the community paper, and volunteer for some organizations and town activity. However, I still miss being in Iran and yearn for one of those family gatherings in Tehran.

The next participant's experience suggests an ironic fact - that continuing and preserving Iranian dance has been much easier in America than it would have been in Iran. Faranak says that women here have so many freedoms that they cannot be compared with Iranian women in Iran.

I am so glad that I immigrated to the U.S. I have been able to receive an education free of any government involvement or harassment. I received my B.S. in psychology. I had some experience in Persian dancing in Iran, and after I finished school here, I decided to pursue teaching Iranian dance to young Iranian girls. It has become my career with several locations around the Bay Area. I 
believe in what I am doing in that it preserves our tradition. It helps the Iranian community come together to celebrate along with their children. It helps the children to be proud of their heritage and be encouraged to learn our dances. The kids see a large support from their own ethnic group where connections are made between people and organizations such as Farsi language schools and charitable organizations. I enjoy what I am doing since I get to express my passion and have a successful career. This career would not have been possible in Iran since it is forbidden for women to dance especially in public. I have gained independence and respect. In America I have had the opportunity to work hard in what I love to do.

Mojghan says that she did not come to the United States with the intention to stay.

However, she has been here since 1993 and has no intention of returning to Iran for a permanent stay even though she would love to be near her family living in Iran.

Although I originally came here to further my education and start a career, my stay here has definitely been due to the lack of political and social freedoms in Iran. I have experienced much freedom of expression in the U.S. that has positively impacted my sense of peace compared to my worrisome life in Iran. I give myself credit for my achievements that I have attained through hard work in the U.S., but the freedoms here plus opportunities have helped me achieve my goals."

Mojghan says that in her experience of living with some American women here, they

seem to be more gender conscious and utilize their freedoms.

I think living on my own in America as I have survived in an open culture has enhanced my personality in that I have become more self sufficient and independent. I can be individualistic and now have individual rights. I am more accepted here in an American society than in my own country. As a consequence of having an established career, my confidence has improved and I can feel as strong as my brothers and I feel equal to them. I am even trusted to make serious decisions in the lives of my nephews after the loss of their father, a role that would have naturally gone to the uncles.

Sharareh while in Iran had heard that women in the United States had so much freedom especially in the absence of the hejab. She thought "life would be comfortable (in U.S.) in that you would work and live the way you want to." She came to America through 
marriage. Fari's brother finished his engineering degree in the United States, but after the revolution, he had no intention of going back to Iran. She adds that although all the members of her family struggled to get here and be together, if hypothetically they all decided to go back to Iran, she would not go with them since she has come to enjoy so many freedoms here. She believes that women have a higher value here than in Iran.

Azar says she picked up ballroom dancing as a hobby in her early forties in the United States as she learned other dances. It became a passion and a career as she has been teaching dance even though she is in her seventies. With the success in dance, she became motivated to try other activities such as making clothes, upholstery, and gardening. She uses dance performances as a way of socializing and keeping her kids close through these shows. She says "There is hope and possibility of progress in America if you want it. I don't think I could have pursued dancing as a hobby or profession in Iran under the current regime since women are not allowed to dance in public. A male dance teacher who worked in America was arrested in Iran and beaten during his visit there."

Bita says, "I am working in a bank and feel independent and confident about my position in my family and this community. I feel as I am an equal partner in my marriage and as a parent. I contribute to my family values and the freedoms I have been able to enjoy in this country. I am glad I have not witnessed or experienced any of the complaints that women in Iran have since I came before the revolution. I can say openly that I am proud of my Iranian identity." 


\section{Classless Society in America}

An American cultural element that almost all participants experienced but only one alluded to was the issue of how American society is less class conscious. Iranian society is more class conscious, and with that comes the pressure to portray oneself as the upper class through wealth, education and even beauty in order to maintain respect in the community, to maintain social ties or to receive better service. For Sima who was from a lower economic class in Iran, this pressure was more severe. Sima says,

As one of the best features of American life, aside from not having to uphold the $h e j a b$, one doesn't have to wear expensive clothes or jewelry at gatherings. You can just wear a pair of jeans when you want to go out of the house and don't have to worry about impressing anyone or being judged based on your appearance. As a girl in Iran you had to be pretty and try to stay young. I knew many young women who had plastic surgery. It was funny because some didn't need any work done but would wear a bandage across their nose to suggest that they did have the money to have plastic surgery.

\section{Challenges of Life in the United States}

The challenges as described by the participants have been few. The point here is that despite some obstacles in this country, these women prefer life here. Fari chose to tolerate the cruel treatment she received in Texas as she had just moved there from Iran shortly after the taking of the American hostages when some Americans were hostile towards Iranians. She struggled to learn the language, and she felt the prejudice and isolation. Neda described her situation: "I did experience a bit of sexism when I was working in the corporate world. I experienced some prejudice mostly when I lived in the Midwest with the Ku Klux Klan, and there are many times that I feel I don't truly belong to this society." Zahra feels that she has adopted the best of both cultures, and it is a 
"blessing." She does not sense any isolation and difficulty with the language. She has, however, after $9 / 11$, been searched more and questioned at the airport because of her nationality. Azar says that coming here in her forties, adjusting to life here, learning the language, going to nursing school, and feeling lonely were very difficult. Sara also expressed loneliness and isolation during the first few years here. "It was rough without my large family here. It took me a while to learn the language which made things that much harder especially understanding the cultural differences." Neda is bothered by the media's objectification of women in America: "Unfortunately women in the western world are also being portrayed as commodities and not as mothers, educators, innovators, and political figures. One thing is for sure, women have more power in the United States, but unfortunately what controls women in this country is the media and Hollywood which again delays them from achieving their true goal in life."

Another challenge in America has been forming a religious or ethnic identity. Almost all the respondents deny that their families are religious, and none of them practice any religion here in America. They say their parents may pray or even avoid drinking alcohol, but they are not fanatical or strict in their religious practices. They claim that their families were open-minded and liberal in the way they raised them. They distance themselves from Islam because of their distaste for the regime. They equate the Muslim religion with approval of the Iranian government. Mohsen Mobasher refers to this in his research by claiming, "For most of them (Iranians in America) religious values and rituals have lost their moral and symbolic significance and no longer function as a guide to their family and social life. In the eyes of many community members, to be a 
devoted practicing Muslim or to attend an Islamic teaching center or a mosque is synonymous with being pro-Khomeini or a sympathizer of the Islamic government in Iran. Consequently, practicing Iranian Muslims who attempt to maintain their religious identity, particularly women who wear the hejab, worry about being labeled as Hezbolahi (Shi' a fundamentalist)." "153 Mobasher extends the argument to suggest that "some Iranians selectively bind together pre-Islamic Persian culture and political ideology in constructing their ethnic identity. The anti-Iranian and anti-Islamic images perpetuated by the media, the deterioration of post revolutionary Iranian society, and the rise of political opposition and activism against the Islamic Republic of Iran have contributed to this Persian ethnic renewal among Iranians in exile." ${ }^{154}$ Some participants distanced not just themselves but all Iranians from Islam as they equated the Muslim religion with the oppressive measures of this regime. Neda says,

Arabs attacked Persia and brought their barbaric customs and traditions to my country. Women stopped having rights as human beings. In Islam women have very minimal rights and they are supposed to live under the mercy of men. That is why after Islam took over. Persian women came down from being queens and leaders to being only there to fulfill men's desires and give birth. After many years, Reza shah was one of the first kings to start giving women rights and freedom by unveiling them and then his son took over the crown and tried to continue his father's footsteps, but he failed. Iranian women began to explore the world of education and took over politics, government, health, education and even the army until the next Arab attack came over Iran and that was the revolution of 1979.

She asserts that although Arabs imposed the Muslim religion on Iranians almost 1,400 years ago, the 1979 revolution is a consequence of that "attack." Neda, whose family had to leave Iran for their religious affiliation as Bahais, rejects all forms of religion by saying

\footnotetext{
${ }^{153}$ Mobasher, 100.

${ }^{154}$ Mobasher, 108.
} 
that "I have no religious affiliations. I now believe that religion has blinded the society from seeing the truth. My mom and dad raised us in a very modern and up to date manner and that is how I am raising my two kids."

\section{Iranian Women's Activism in America}

Although several factors have been mentioned as reasons for Iranian women to have chosen the United States as the ideal destination, the main goal for many of them has been to reject social, political, and religious oppression that has limited their individual rights, social mobility, educational opportunities, and economic independence. These immigrants have come here to enjoy the legal and civil rights allowed to women here, which will, consequently, improve their social and economic status. Democracy and equality offer educational and economic opportunities to them, and their activities and experiences during their short stay in the United States are a testament to this. The women have been able to continue their political activities in support of women's rights here. Because of their activism, awareness of the oppressive measures practiced against women has been enhanced and the public has become educated, not just in the U.S., but also in Iran, through numerous publications, internet, radio, and television programs. Iranian women immigrants have formed formal organizations and informal groups with a variety of agendas in the United States.

Women's Forum Against Fundamentalism in Iran is an example of these organizations. Its mission statement asserts:

WFAFI is committed to promoting a greater awareness of the challenges women face living under fundamentalist regimes such as that of Iran. Our tasks range from raising public awareness, conducting research projects and initiating 
outreach programs-to policy discussions and analysis. We firmly believe the political presence, participation and leadership of women are instrumental to achieving social, political and economic equality.

The activities of WFAFI include:

Support[ing] the democratic aspiration of the Iranian people, particularly women, in their struggle against Islamic fundamentalism. Support the efforts of Iranian women in areas of political leadership, economic development, and education. Network with relevant institutions and organizations in an effort to achieve our stated mission. Distribute E-Zan (our monthly newsletter), broadcast Farsi radio to Iran, publish fact sheets and policy briefs on pertinent subjects.

On July 27, 2005 WFAFI presented a report of its six-month research project on Iranian opposition organizations to members of Congress. The president of WFAFI, Faezeh Khalili, stressed: "Our goal is to make sure that our policy makers in Washington have a clear understanding of the expectations of Iranian women. We feel Iran's equality movement should figure at the center of an urgently needed policy toward the regime in Tehran." Another member of WFAFI, Mina Entezari, who is a human rights activist and a former political prisoner who spent seven years in incarceration, told the House briefing how female prisoners were treated and provided names of many who were executed by Tehran's regime. Referring to a 1988 massacre, she said this "was not only a crime against Iranian freedom lovers; this was a crime against humanity. The root of this crime is the religious fundamentalism in Tehran." 155

Other organizations have built social and professional networks to offer legal and medical advice, offer scholarships, and preserve and revive Iranian history, language and

\footnotetext{
${ }^{155}$ Women's Forum Against Fundamentalism in Iran, http://www.wfafi.org, (accessed October 11, 2006), $1-4$.
} 
culture, as well as address a host of human rights issues. Some of these organizations include the Iranian Federated Women's Club, the Iranian Human Rights Working Group, the Iranian Professional Women, and the Center for the Persian Culture, the Persian Community Centers, and the Association for Middle East Women's Studies among others. Women have been able to practice their religious beliefs here openly by forming religious communities such as the Iranian Zoroastrian Women's Organization, the Rumi Art Society, and the International Council of Iranian Christians. ${ }^{156}$ Individual women here have provided financial help to women in Iran that has allowed for feeding, education, and fees for divorces and abortions instigated by women. ${ }^{157}$

Iranian women have participated in the American political system and have been candidates for public offices. One example is Sara Amir who was a candidate for the Green Party. She ran for Lieutenant Governor in California in 1998, when she received a quarter of a million votes. ${ }^{158}$ Women have also taken an active role in fighting discrimination and violence in the aftermath of the hostage crisis and the 9/11 tragedy. They fight the stigmatization of Middle Eastern women as passive, victimized, or fanatical by forming organizations such as The American Iranian Anti-Discrimination Center.

Some Iranian women have pursued arts and music to express their political, sexual and social identities. The arts and media are severely censored by the Iranian government. Women are not allowed to sing in public; there are strict religious

\footnotetext{
${ }^{156}$ Persian Professional and Cultural Organizations, http://www.farsinet.com/ipco/ , 12/8/2006.

${ }^{157}$ This information is from my personal experiences as well as my conversations with many Iranian women throughout my twenty- two-year residence in the United States.

${ }^{158}$ Sara Amir, http://change-link.org/greencnadidate.htm, (accessed December 7, 2006).
} 
guidelines for all art forms; films and novels cannot explore gender relations based on love and sexuality. These strictures have not only prohibited women from expressing their identities or expectations, but also have caused misconceptions about gender roles. ${ }^{159}$ Women's sexuality has been suppressed with the use of the hejab in movies. Movies are one of the few forms of entertainment allowed to the public, yet many films have subtly addressed a host of women's issues such as child custody, divorce, poverty, abortion, and prostitution without a direct attack on government authorities for such social ills. Films have to be approved by the government, and they shown in the theaters for a period of time recommended by the government. Since the 1990s, Iranian movies with their simplistic and humanistic messages have claimed hundreds of awards internationally, but many of these movies are not allowed to be seen in Iran and are smuggled out of the country for distribution to the American and European audiences who are increasingly more receptive of them. Two examples of these films include "Children of Heaven", which was nominated for an Oscar in 2002, and "Taste of Cherry" that won the Palme d'or at Cannes. ${ }^{160}$

Women are used to define conservatism in films and elsewhere. When selfexpression is limited by religious guidelines, so is art as it requires the most freedom from religion, tradition, and politics. There are several Iranian women producers in America who have devoted their efforts to making movies about gender inequality in Iran as well as other forms of social, economic, and political oppression. One example is Manijeh Hekmat who produced a movie about female prisoners in Iran titled, “Women's

\footnotetext{
${ }^{159}$ Moaveni, 48-52.

${ }^{160}$ San Francisco Chronicle, Tuesday, Feb. 10, 2004, http://www.sfgate.com, (accessed 12/10/2006).
} 
Prison." Despite her efforts to smuggle the film into Iran, she did not succeed as the government became aware of her attempts and threatened her with imprisonment. ${ }^{161}$

The Iranian Women's Studies Foundation in America is one group responsible for the promotion, recognition, and communication among these artists. Its statement of purpose follows:

The Iranian Women's Studies Foundation is a non-profit organization. It has no affiliation to any political or religious group or organization, and aims to provide a forum for the exchange of ideas on issues related to Iranian women, to disseminate information on Iranian women's achievements, and to establish a network of communication among communities of Iranian women [Its mission] is approached through scholarly presentations, art exhibitions, and artistic or dramatic performances. The history of Iran has consisted for the most part of male-dominated narratives and accounts of men's exploits and achievements. IWSF attempts to offer a different perspective on Iran's history by protecting, preserving and propagating the works of Iranian women. Since 1990, the IWSF has conducted annual conferences in various cities around the world. At these gatherings, academics and professionals interested in issues related to Iranian women congregate to share the result of their research, to celebrate the artistic accomplishments of Iranian women, and to exchange ideas and plans for the future. The IWSF publishes the proceedings of its annual conferences in the journal of the IWSF in which works by and about Iranian women are collected annually. ${ }^{162}$

There is no open and public dialogue among women in Iran about the numerous social and economic problems that have sent many into prostitution despite their religious and moral beliefs. ${ }^{163}$ There is no conversation about the sexual harassment used against women in public and at work that forces them out of their jobs. There are not enough efforts by the governmental to curb the poverty experienced by so many women

\footnotetext{
${ }^{161}$ Iranian Movies, http://www.newrozfilm.com, (accessed 12/10/2006).

${ }^{162}$ The Iranian Women's Studies Foundation. http://www.iranwomen.org, 11/13/2006.

${ }^{163} \mathrm{I}$ viewed a documentary in San Jose in June of 2005, called Prostitution in Iran by Mahjeed Hamedi as he secretly interviewed many Iranian women forced into prostitution by poverty. This documentary had to be smuggled out of Iran.
} 
as they become dependent on their husbands and as their husbands have several other wives without having the financial means to support them. There is not enough attention or enforcement of laws against domestic abuse and child abuse.

An additional element that has contributed to the freedom and cohesiveness of the Iranian community in America has been the political conflicts between the United States and the Islamic Republic. There is no cooperation between the two countries over monitoring or return of exiles or those Iranians in the United States who express their objection to the Iranian regime. Rather in America, these groups experience support and sympathy for their grievances and their rejection of the Iranian government. This is not the case in some European countries such as the Netherlands, and resulting fear has caused secrecy and apprehension among the Iranian community there. ${ }^{164}$ Mahasti confirms this point in suggesting that the common denominator among Iranians in America is objection to the Iranian regime.

The participants in this study have been well integrated into life in America, and they do not want to lose some of their freedom and independence by going back to Iran. They enjoy the equal treatment under the law despite many challenges of integration. The evidence adduced in the within study supports and concurs with that in Hashemi and Bozorgmehr's research in that it suggests Iranian women in America attribute their achievements in their personal and professional lives to their own personal discipline and determination. This, in turn, once again suggests that the individualistic American society has provided the opportunity for these women to make powerful statements and

${ }^{164}$ Ghorashi, 125. 
use their power to negotiate their gender roles. Mojghan says "I give myself credit for my achievements that I have attained through hard work in the U.S." (A-29) 


\section{Chapter VI.}

\section{Conclusion}

There are legal/religious and cultural/social obstacles to women's freedoms, and an examination of Iran's history can help unravel the complex structure of contemporary gender roles. Therefore, it is not the purpose of this research to paint a monolithic image of the Iranian government as the only responsible figure for women's condition or status in Iran. There are liberal factions within the government, as they include many men and women who are pushing for more legal and social rights of all Iranians. ${ }^{165}$ Islam is not homogenous. Women's experience in relation to Islam is diverse, and matters are even more complex in that gender is a dynamic element, so by no means does this study suggest that there is a direct correlation between immigration and the Islamic regime in Iran. Rather it hopes to shed light on the process of immigration and to contribute to understanding this underrepresented community of Iranians in America. Iranian women have experienced oppression and sexism throughout their country's long history through kings and clerics - yet they have continued their resistance and maintained their resilience to gain equal rights. ${ }^{166}$

Iranian women too are diverse in their level of secularism or religiosity, traditionalism, or modernism. For the most part, women want more legal and social freedoms. ${ }^{167}$ This is not to say that there is total equality in America for women. Iranian women in America are still fighting patriarchy and sexism. Many are working to achieve

\footnotetext{
${ }^{165}$ Yeganeh, 4-5.

${ }^{166}$ Sedghi, 182, 202-203.

${ }^{167}$ Povey, 44-72.
} 
legal, economic, and social equality such as equal pay for equal work. It should be mentioned that Iranian women, just as American women, experience discrimination plus they also face the challenges of acculturation, learning the language, and occasional prejudice.

The journey to the U.S. for these women has not been an escape, rather a journey to democracy and a gesture of agency. Many women in Iran are active participants in a movement towards civil rights and democracy. They demand economic, legal, social, and political equality, as they demonstrate a different kind of agency by facing the confines and limitations imposed on women in their homeland. ${ }^{168}$ Valentine Moghadam shows how women in Iran under the current regime are using different interpretations of Islam to empower themselves and to circumvent some of the imposed restrictions. Hashemi reminds readers of a broader global conflict for women: "In the past few decades there have been a few developments that have influenced women's status globally, especially in the developing countries. In the latter part of the Twentieth Century we have seen a move in many societies toward the recognition of human rights, positively affecting gender equity. At the same time, we have witnessed a strengthening of nationalism and religious fundamentalism which has had a negative impact on gender equality in many other societies during the same period." 169

This study researched the question of whether Iranian women came to the U.S. for socio-political reasons or economic opportunities. The hypothesis was that Iranian women came to the U.S. mostly for socio-political and religious freedoms and not just for

\footnotetext{
${ }^{168}$ Povey, 65, 67, 69.

${ }^{169}$ Hashemi, 237.
} 
economic opportunities. It began by investigating the causes of migration of female immigrants from Iran in the past few decades, especially in the post-1979 revolution when women's rights were further diminished when patriarchy dominated the political and social system under the Islamic regime. It asked a series of question that involved their economic status in Iran in comparison to that in the U.S. It investigated their gender roles here and in Iran, their consciousness of power and authority within family and work, opportunities in work and in society, and legal rights here and in Iran. The participants, based on their socio-economic status, ethnicity, religion, class, family background, age, and education, have encountered challenges, been able to take advantage of opportunities, developed various degrees of awareness, challenged patriarchy, and achieved different levels of independence. Their achievements are individual. However, they have all come to enjoy and appreciate American legal, social, and religious freedom (religious freedom could mean that they are not forced to practice one national religion; often they have abandoned all religions).

It can also be concluded that although women do prefer the sociopolitical freedoms as the main element of their stay in America, economic opportunities cannot be separated from sociopolitical freedoms. They reinforce and sustain each other. Legal rights for women and social acceptance of women's equality provide economic opportunities; economic opportunities provide independence and education that lead to legal and social equality. None of the participants said that they came here for work or financial opportunities. If anything, some compromised financial and class status with little or no guarantee that they would be financially secure here. They were optimistic 
about the financial opportunities here, but this fact alone did not persuade them to make the migration. They were aware of the independence and empowerment that would legally be allowed to women in America and understood how that could increase financial opportunities. They were also conscious that the gender inequalities in Iran stemmed from the lack of economic independence from sexism and patriarchy in the legal and social systems. This inhibited their freedom and made them dependent on men. They lost social mobility along with many individual and civil rights.

Having said that, none of them came here for the economic reasons alone. Culturally Iranian women are not expected to support their families financially. In a patriarchal society such as Iran, it is often expected that men will provide for the family. These women were not obligated or forced to pursue work in America or anywhere else. Almost all have low-end jobs or have chosen not to work. They all agree that there is definitely more freedom for women in America.

Although this sample study is limited and does not suggest that it represents the views of the majority of Iranian female immigrants in America, it is, nevertheless, a small window that allows a look at this community and a building block for extended studies in this field. As a fairly new component of the American society, this community should be understood. Its expectations and grievances need to be evaluated. After researching much of the published work in this area, this thesis has concluded that there is very little work on Middle Eastern women independent of their families and the general migration. There is little information on patterns of migration from this region, causes of migration, or the process of migration. There are few studies of their socio-political environment in 
their home country and even fewer on their acculturation in the host country. We do not know how they form their identities or shape their lives with a mixture of values and practices. We need to know more about Iranian immigrant women's consciousness of the challenges that they have encountered, their activities and organizations, their formal and informal resistance in politics, their resilience and successes, and their sacrifices and hopes.

There is definitely a need for a dialogue about and among this group of women from Iran and from the Middle East in general, who historically have shared the experience of discrimination on multiple levels because of their religion and legal and social systems. This dialogue will benefit all women and all humanity as it draws attention to the needs of not only women but also to what members of the human race must possess to live not just functional lives but civilized ones. 


\section{Bibliography}

Adelkhah, Fariba. Being Modern in Iran. New York: Columbia University Press, 2000.

Afary, Janet. The Iranian Constitutional Revolution, 1906-1911: Grassroots Democracy, Social Democracy, and the Origin of Feminism. New York: Columbia University Press, 1996.

Amin, Carmon Michael. The Making of the Modern Iranian Woman: Gender, State Policy, and Popular Culture, 1865-1946. Gainesville: University Press of Florida, 2002.

Bayat, Mongol. Iran's First Revolution: Shism and the Constitutional Revolution of 1905-1909. New York: Oxford University Press, 1991.

Bozorgmehr, Mehdi. "From Iranian Studies to Studies of Iranians in the United States." Iranian Studies 31, no.1 (1998): 5-30.

Bozorgmehr, Mehdi. "Internal Ethnicity: Iranians in Los Angeles." Sociological Perspective 40, no. 3 (1997): 387-408.

Bozzoli, Belina. Women of Phokeng: Consciousness, Life Strategy, and Migrancy in South Africa, 1900-1983. Portsmouth, NH: Heineman, 1991.

Briggs, Vernon M. and Stephen Moore. Still an Open Door? U.S. Immigration Policy and the American Economy. Washington, D.C.: The American University Press, 1994.

Briks, J.S. and C.A. Sinclair. International Migration and Development in the Arab Region. Geneva: International Labour Office: 1980.

Ghaffarian, Shireen. "The Acculturation of Iranians in the United States." The Journal of Social Psychology 127, no.6 (May 1987): 565-571.

Ghorashi, Halleh. Ways to Survive, Battles to Win: Iranian Women Exiles in the Netherlands and the United States. New York: Nova Science Publisher, 2003.

Hahighat, Elhum. "A Comparative Analysis of Neopatriarchy and Female Labor Force Participation in Islamic Countries." Electronic Journal of Sociology 7, no. 1 (2005): 1-26. http://www.sociology.org (accessed November 8, 2009).

Hashemi, Mahasti. "Immigrants and Exiles: Iranian Women in the United States." $\mathrm{PhD}$ diss., Rutgers, the State University of New Jersey-New Brunswick, 2006. 
Hojat, Mohammadreza. "Gender Differences in Traditional Attitudes toward Marriage and the Family: An Empirical Study of Iranian Immigrants in the United States." Journal of Family 21, no. 4 (May 2000): 419-434.

Karim, Persis M. and Al Young, eds. Let Me Tell You Where I've Been: New Writings by Women of the Iranian Diaspora. Fayetteville: The University of Arkansas Press, 2006.

Keshishian, Flora. "Acculturation, Communication, and the U.S. Mass Media: The Experience of an Iranian Immigrant." The Howard Journal of Communication 11 , no. 2 (2000): 93-106.

"Levels and Trends of International Migration to Selected Countries in Asia-United Nations." Department of Economic and Social Affairs Population Division. New York, 2003.

Menashri, David. Post Revolutionary Politics in Iran: Religion, Society and Power. London: Frank Cass, 2001.

Mir-Hosseini, Ziba. "Iranian Cinema: Art, Society and the State." Middle East Report 219 (Summer 2001): 26-29.

Moaveni, Azadeh. Lipstick Jihad: A Memoir of Growing Up Iranian in America and American in Iran. New York: Public Affairs, 2005.

Mobasher, Mohsen. "Cultural Trauma and Ethnic Identity Formation among Iranian Immigrants in the United States." The American Behavioral Scientist 50 (2006): 100-118.

Moghadam, Valentine M. "Islamic Feminism and its Discontents: Toward a Resolution of the Debate." Signs 27, no. 4 (Summer 2002): 1135-1171.

Nafisi, Azar. Reading Lolita in Tehran. New York: Random House, 2004.

Povey, Elaheh Rostami. "Feminist Contestations of Institutional Domains in Iran." Feminist Review no. 69 (Winter 2001): 44-72.

Sedghi, Hamideh. Women and Politics in Iran: Veiling, Unveiling, and Reveiling. Cambridge: Cambridge University Press, 2007.

Seife, Susan. "Effects of outside employment on lower class Iranian women and their children." PhD diss., Syracuse University, 1985. 
Shavarini, Mitra K. Educating Immigrants: Experiences of Second Generation Iranians. New York: LFB Scholarly Publishing LLC, 2004.

Waldinger, Roger and Mehdi Bozorgmehr, eds. Ethnic Los Angeles. New York: Russell Sage Foundation, 1996.

Yeganeh, Nahid. "Women, Nationalism and Islam in Contemporary Political Discourse in Iran." Feminist Review no 44 (Summer 1993): 3-18.

Zamudio, Patricia. "Huejuquillense Immigrants in Chicago: Culture, Gender, and Community in the Shaping of Consciousness." PhD diss., Northwestern University, 1999.

Zolberg, Aristide R. and Peter M. Benda-Berghahn, eds. Global Migrants, Global Refugees: Problems and Solutions. New York: Oxford University Press, 2001.

\section{Internet Sources}

Iranian Movies. http://www.newrozfilm.com. Accessed December 10, 2006

Iranian Women's Studies Foundation. http://www.iranwomen.org. Accessed November $13,2006$.

Karim, Persis M. and Al Young, eds. Let me Tell You Where I've Been: New Writings by Women of the Iranian Diaspora. Fayetteville, AR: University of Arkansas Press, 2006, 2, quoted in Stephen Kaufman, "Iranian Women in Exile Finding Voices Through Literature: Lack of censorship spawns creative outlet for women to tell their own stories," .Payvand's Iran News 11/07/06, http://www.payvand.com/news/06/nov/1079.html . Accessed November 10, 2006.

Kaufman, Stephen. "Iranian Women in Exile Finding Voices Through Literature: Lack of censorship spawns creative outlet for women to tell their own stories." . Payvand's Iran News 11/07/06. http://www.payvand.com/news/06/nov/1079,html. Accessed November 10, 2006.

Li, Xin. "Iranian Women's Rights Severely Restricted." http://www.learningpartnership.org. Accessed November 10, 2006.

Persian Professional and Cultural Organizations. http://www.farsinet.com/ipco/. Accessed December 8, 2006. 
Pezhvak Magazine, http://news.newsamericamedia.org. Accessed December 7, 2006.

San Francisco Chronicle, Tuesday Feb. 10, 2004 http://www.sfgate.com. Accessed December 10, 2006.

Sara Amir. http://change-link.org/greencandidate.htm. Accessed December 7, 2006.

Women's Forum Against Fundamentalism in Iran. 1-4. http://www.wfafi.org. Accessed October 11, 2006 
Appendix A:

\section{Participants Responses}

The following are the statements of the participants either translated by the author or received as written responses. The original written and recorded interviews are kept in a locked cabinet in author's possession. The participants were divided by the time of their immigration in the methodology section of the study. However in this Appendix their pseudonyms are numbered for easier reading since most of their names are foreign to many readers.

1. Neda. "I left my country when I was thirteen with my family in 1985. My father took religious asylum in Pakistan for two years and then came to the United States with help from the United Nations. My family was part of the religious minority called Bahais and just like Christian, Jews and Zoroastians, they were under a lot of pressure. The 1979 revolution in Iran had a major effect on my family's decision to leave Iran. After the revolution the regime was hostile towards different social, religious and political sectors of the population. My family had no choice but to leave the country in search of religious and political freedom." Neda goes deep into the Iranian history to blame the Arabs for imposing the Islamic religion on Iranians by saying, "Arabs attacked Persia and brought their barbaric customs and traditions to my country. Women stopped having rights as human beings. In Islam women have very minimal rights and they are supposed to live under the mercy of men. This is why after Islam took over, Persian women came down from being queens and leaders to being only there to fulfill men's desires and give birth. After many years, Reza shah was one of the first kings to start 
giving women rights and freedom by unveiling them and then his son took over the crown and tried to continue his father's footsteps but he failed. Iranian women began to explore the world of education and took over politics, government, health, education and even the army until the next Arab attack came over Iran and that was the revolution of 1979. Women were forced to wear the veil once more and refrain from holding political and high profile jobs. They were banned from voting and taking a seat in the senate or becoming judges. Socially, they have a very hard time if they decide to leave a marriage due to any circumstances. They don't have the right to leave the country or have custody of their children even if the father is not capable of raising the kids. In the recent years there have been some women's movements for equal rights. There are more women enrolled in the universities than ever and we now have more working mothers than before, but the true social and cultural freedom and rights are still not there. My family immigrated to the United States due to the regime's religious intolerance of the Bahais. My father was harassed due to his religious beliefs. My cousin was sentenced to death only due to being a Baha'i and his children were expelled from school. My aunt who was an educated woman with a high profile job before the revolution was fired from her job along with twenty other Baha'i employees. Hejab is like a leash around the dog's neck. Unfortunately women in the western world are also being portrayed as commodities and not as mothers, educators, innovators, and political figures. One thing is for sure, women have more power in the United States, but unfortunately what controls women in this country is the media and Hollywood which again slows them from achieving their true goals in life. My expectation of the United States prior to coming here was to be able to 
use my resources just like men and get the highest level of education to gain power and knowledge. I have certainly been brought up more openly than I would have been in Iran. I am a very social and free-spirited woman and I was able to be myself at least around the non Iranian crowd. Professionally, I am a stay-at-home mom, and I would have probably been the same in Iran even though I hold a master's in business administrations. In America I have had the freedom to travel, be educated and social with no one questioning me. I did experience a bit of sexism when I was working in the corporate world. I experienced some prejudice mostly when I lived in the Midwest, with the Ku Klux Klan, and there are many times that I feel I don't truly belong to this society." Neda who is married to an Iranian man and has two young children has this to say about Iranian men and American men: "Iranian men need to learn to accept the fact that women too can be appreciated even though they are only moms or housewives. They need to respect women who make money and work outside the home and treat them equally. I believe it's not just Iranian men who need to change; I believe all men need to change their attitudes regarding stay-at-home moms. I believe moms have one of the most important jobs in the world and that is to raise kids. Iranian men here (in America) have no choice but to acknowledge the laws that were set by the women's movement in this country. Iranian men in Iran don't have to follow any laws regarding women's rights so they just live their lives based on what they have learned in society. Women are not sitting around in either country. They are rebelling and letting their voices be heard and fight patriarchy. I have no religious affiliations. I now believe that religion has blinded 
the society from seeing the truth. My mom and dad raised us in a very modern and up to date manner and that is how I am raising my two kids."

2. Mina came to the United States as a single mother after divorcing her husband for his infidelity in 1986 with every intention to stay in this country. She had two daughters, ages twelve and thirteen, who she intended to bring with her to America. After going to Turkey and applying for the American visas for all of them, the embassy only granted her a visitor's visa and not her daughters. She was forced with much grievance to separate from her two girls. She says, "I couldn't leave my daughters, but at such a young age they were so smart and determined not go back to live in Iran that they convinced me to leave them behind. They told me that they were willing to tolerate the sadness of being away from their mom for a few years if it meant eventually they could come to the U.S. through me. If I stayed with them in Iran, they could never have the chance to come here. I had to send them to stay with some family members in Italy for three years while I tried to establish residency. I married an American man to gain my green card, so I can apply through family visas for my daughters. It cost me ten thousand dollars for each one of my girls to have a lawyer help them come here. I decided to leave Iran. After I saw how they treated me as a woman, I did not want to subject my daughters to that life as women's freedoms were diminishing. My daughters and I were harassed on the street for not upholding the proper hejab and were put in temporary jail for it. This was two years after the revolution." Mina was educated and trained by American Bell Company, and she managed twenty people at the phone company during the Shah. She said she was independent socially and economically before the revolution in Tehran. She 
had divorced her husband at the age of twenty two for cheating on her. "My family was mad at me for five years for divorcing my husband. My dad unlike my mom was very conservative and married me off against my will. I wanted to be a singer and had some training, but the revolution put an end to this dream as women are not allowed to sing publicly. My supervisors and upper management had urged us to go to the streets and protest the Shah's regime for suppressing freedom and killing the defiant youth.

Although I didn't have any political or religious affiliation, I felt obliged to listen to their orders and partake in the protests. I plus many others felt deceived as the new regime didn't deliver on its promises of the revolution. I saw many freedoms disappearing especially for women. I was punished after the revolution for what I had done before the revolution, such as dressing in the western fashion, revealing my legs in short skirts which was legal at the time. My punishment included my dismissal from work. My own immediate coworkers and managers reported me to the government for being too western before the revolution. It was called the cleansing process where they cleared companies of people who held western values which in this case meant not upholding the hejab. Government jobs and entrance into university required the knowledge of the Quran, the daily prayers and overall Muslim behavior. I decided to move to the U.S. so my daughters can have better lives and have more freedom to do and wear whatever they wanted, and to have a better education free of religious requirement. In Iran I had hoped to learn to be a makeup artist and an aesthetician now in America due to financial pressures I had to settle for doing nails just to make money to support myself and my daughters. I would rather be free and independent even if I have to tolerate poverty. I 
sacrificed my financial comfort in Iran for life in America for this very reason. I am glad that I came, for now I have two educated, strong and independent girls who make me very proud. I worry about my financial future as I now have to take care of my mother who suffers from multiple sclerosis. I am suffering from much financial difficulties, but like other Iranian women I think we are all hard working and loyal in relationships and in life. I had married an American man. After five years of marriage he said he was gay and wanted to separate. I thanked him for helping me to establish my residency through marriage that in turn helped me bring my daughters here. I didn't ask for any financial support that I badly needed and he never offered. For a while, I was living with my sister in America and my two daughters. I was grateful for my sister's financial support. One night when my daughters and I were staying with her, her husband tried to sleep with me, and when I told my sister about his intentions, not only did he deny it but threaten to report me to the immigration for deportation. I was so fearful of being sent back to Iran that I left my sisters house and struggled on my own to raise my daughters alone. Iranian men don't deeply care about you; they are deceiving. They expect more domesticity of Iranian women than they do from American women. I was going out with an Iranian professor here for twelve years who secretly had a relationship with his ex-wife. They do have good manners and pay for dinner which is nice, but I don't let them have any thing on me so I always return the favor by making them dinner. American men expect you to pay for yourself even on a date."

3. Fari came here at the age of thirteen in 1985 with her mother and sister. Her single mother had decided after the revolution to have her son who was already in 
America stay here. He had come to the United States for education two years before the revolution, and she wanted her whole family to live in America. Fari remembers going to Turkey from Iran to obtain her visa to come to America. She remembers long lines of Iranians waiting hours outside the American embassy and how important and life-altering it was for any of them including her to obtain a visa. Fari recalls being thirteen in Iran soon after the revolution. "I remember going out for a sandwich with my girlfriends after school and the principal saw me. She complained to my mother that going out to eat with other girls was loose behavior, behavior like a prostitute." Fari remembers all the women in her family hated the mandatory hejab even more than she did. She says she was harassed often by the same people that only months before the revolution were open to women having freedoms such as wearing short skirts and revealing their hair. She couldn't believe that girls as young as nine years old had to cover their hair. Her mom who was not particularly religious and often had big gatherings at her house with plenty of dancing and drinking had to cover her hair and could not have such parties. At such a young age, Fari became conscious of gender inequalities mostly due to the changes she experienced during the revolution. Her mother and not so much her older brother supported the revolution, but like everyone else she too was deceived as many promises of freedom, independence, and an improved economic situation were not fulfilled. "My family," Fari says "was pretty open and liberal and had no political affiliation to the leftists or religious organization." They lived in central Tehran, the capital, where the revolutionary movement was all around them and they got swept into it. They never thought the revolution would mean the loss of freedoms for women; otherwise, many 
women she knew would not have participated. Her brother finished his engineering degree in the United States, but after the revolution, he had no intention of going back to Iran. She adds that although they all came here to be together, if the rest of her family decided to go back to Iran, she would not go back since she has come to enjoy so many freedoms here, especially not having to wear the hejab. She knows that women here enjoy many legal rights in particular as it pertains to family and work. She chose to tolerate the cruel treatment she received in Texas as she had just moved there from Iran shortly after the taking of the American hostages when some Americans were hostile towards Iranians. She struggled to learn the language, and she felt the prejudice and isolation. She was convinced, however, that women in Iran would have a more difficult time in their own country. She used an example that if a wife in Iran becomes a widow and her husband had an orchard, she could not own the property but she may inherit the trees on the property. It would be the son or a male relative of the husband who could gain ownership of the property. She goes on to say that Shirin Ebadi is fighting laws against women becoming financially empowered and independent. Young people are fighting the hejab in various ways by wearing a smaller scarf that shows more hair, wearing more makeup, wearing tighter and shorter montoe (a loose cover like a long coat that covers the arms and almost the entire body down to the ankles). The young girls who are defiant get harassed by the male and female government guards. When many of them are asked by the guards why have you worn makeup or tight clothes, often their response is that it should be their choice not the government's business to dictate their attire. Fari talked about how even though women do go to college the jobs are often given 
to men in the belief that they are the sole supporters of their families. Often women cannot get protection for their children. She gave an example of an eight-year-old boy having his hand crushed as it was placed under the wheel of a moving car as a way for the regime to show that severe punishment will be enforced in cases of stealing. She gave another example of a friend who lost the custody of her children for divorcing her husband. Fari has no desire to go back to live in Iran under the current regime, but she has maintained a closeness to and preference for the Iranian way of life. She married an Iranian man with whom she is very pleased. She has no complaints about him. She says he has spent most of his life here and so he is fair in sharing the house work and in the raising of their son. Several times Fari reiterated that she got really lucky to find such an Iranian man, implying that other Iranian men are not so egalitarian and are more patriarchal in their treatment of their wives. "He provides for the family. He is an independent contractor," she says. She herself is a hair stylist. She says "my mother never pressured us to do anything we didn't want to whether in school or life. She is very open minded."

4. Azar says, "I came to the U.S. for the first time in 1969 to visit my daughter who was going to school here studying economics. I then visited several other times before the revolution. I brought my son here who was thirteen years old to stay with my daughter. Two years after the revolution, getting an American visa became increasingly difficult. The consulates knew that after the revolution Iranians would no longer just visit the U.S. They would come to stay and since the relationship between the two countries had been damaged, the visas were given with many conditions that would guarantee your 
return to Iran such as having young kids in Iran or a large amount of wealth. I applied with my other daughter who was under eighteen. I had to pay about six thousand dollars, which at that time was a lot of money to a lawyer plus my daughter in America had to show that she could financially support us during our stay here. I was finally able to come here with my daughter after going to Turkey first, then waiting three years in Germany, which was very difficult since we didn't speak the language and didn't have most of the comforts we enjoyed in Iran. My husband was still in Iran, and it took years for him to join us in the U.S. We had come with every intention to stay because life had become so difficult in Iran. In Tehran, at one point, the government only allowed the doctors and some other professionals to drive their own cars. The city was so restless and unstable that government was afraid of allowing too much mobility to people who might gather for protests. The cost of gas had also skyrocketed. I have not gone to visit in over twenty years, but I am hoping to go back one day. Most of my family is in Germany and America. If it hadn't been for the revolution I would have never come to stay. I would just visit the U.S. My daughter in Germany quickly learned German and got her medical doctor degree and became a clinical professor in the pharmaceutical field. I know she thinks that life in Iran especially for women is very limited in terms of opportunities and freedom. I was a dulla (a person who helps with childbirth) at the hospital. A couple of years after the revolution we had to cover our heads if a male patient entered our work place. It was increasingly difficult to uphold the hejab. It was so hot, and we had to cover ourselves in the extreme heat, we couldn't wear makeup and were searched for possessing it at work. This bothered many women. If we had stayed in Iran, I think life 
would have been so difficult especially for my daughter. She was only thirteen when I brought her to America, but she already knew that she didn't like it there. "My daughters and I went to a beach we had visited several times during the Shah era, but after the revolution we were so afraid of being arrested and go to jail for not wearing socks and covering our feet in the sand. It was not fun. All we felt was fear, lots of fear. It is hard to observe the hejab even for the women who have been brought up under this regime. I did not want to subject my daughters to that life. The young girls especially who see women on internet and satellite shows without the Hejab are often resisting it. After the revolution, there was less consumerism for us women. There weren't as many consumer goods and there wasn't as much need for some things like makeup and western clothes since we had to be covered up, and conserving resources was being promoted. We had rented out our apartments to the Americans who worked in Iran and the ambassadors. When they had to quickly leave the country during the revolution, we helped ship their things to them that they had left behind. My father liked the Shah. I myself had never heard of Khomeini. I wasn't religious nor was I leftist, I liked the Shah. I think the Islamic groups fought the Shah so they could be in power not because of any ideological reasons. Many people had to become religious after the revolution so they could get jobs, since they had to pass religious questionnaire when they were interviewed for jobs, such as "do you know how to pray (the prayer that Muslims do five times a day in Arabic) or if they had familiarity with the Quran and religious figures. In America there is a lot of freedom. You can progress and succeed. I have to say I mainly came for personal freedom and to provide a free and secure future for my children. I hope life would 
become better in Iran someday. I came to the U.S. just after the release of the hostages. I wasn't too anxious to tell everyone I am Iranian, but I knew if they were upset they were upset with the regime of Iran not the people of Iran. I did go directly to Los Angeles where there is a large group of Iranians where many of them had just arrived in the U.S. I was in my early forties. Lots of them had left for political reasons. Others had cooperated or had been part of the Shah's regime such as military officials who were afraid to identify themselves even once in America. My parents were not religious, but they were able to tolerate the regime better than the young people. I remember the war with Iraq. We would hide out at nights in fear of the bombing by Iraqi planes. There was a shortage of food. Food, gas, oil all had to be rationed. Even if you could afford the high price of the food in the open market without government assistance or coupons, the food supply was limited. Financially we were very independent with several properties that we just left behind. My daughter and I went back to Iran once after the revolution and saw that some people had taken over four of our villas by the Caspian Sea. When we reported them to the government, we realized it was really the government that had confiscated our property as they resented all the people who left Iran and labeled them as pro-Shah or western, and they legitimized their confiscation by saying that it was their job to provide for the poor and that the poor needed these homes more than us. I know that this had happened to many others who left the country, some who had left out of panic and fear of the new regime. I left Iran in 1981. It was a bad revolution. So many got killed after the revolution for not being Muslim, especially the military officials. It was so frightening. Meanwhile many people from Tehran's surrounding states attacked 
the capital and would take what they could. There was somewhat of lawlessness and chaos. I remember one day that my neighbor was crying, not just a sad cry but a cry out of severe heartache. When I asked her why she was crying, she told me that her daughter was arrested for possessing anti-regime books and magazines and was killed within two days of her arrest. So even though I wasn't political, the fear all around me made it uncomfortable to live there. It was depressing not to see women on TV. Since the women didn't have hejab in the foreign movies, they would black out their faces. It seemed that we as women were erased. It was hard to observe the hejab even for the women who have been brought up under this regime. The young girls especially who see women on the internet and satellite shows without the hejab are often resisting the hejab. At the workplace, I didn't experience any sexual harassment. I had worked there for years and people knew me as established and showed some respect, but after the revolution the tension was not so much between the men and women; rather it was between the pro-revolution and anti-revolution groups, so you had to know who you are talking to when you want to say something. Coming here and finally adjusting to life here was difficult - learning the language, going to nursing school, and being lonely. Fortunately there are many Iranian organizations for contact and help. I went to ballroom dancing classes as a hobby with the encouragement of my son in my early forties, and I eventually learned other dances. I have been teaching dance for a few years and continue to enjoy it as a passion at the age of seventy. After learning to dance, I was motivated to pursue other art forms such as making clothes, upholstery, gardening and use dancing to socialize and keep my kids close through parties. There is hope and possibility of 
progress in America if you want it. I don't think I could have pursued dancing as a hobby or profession in Iran under the current regime since women are not allowed to dance in public. A male dance teacher who worked in America was arrested in Iran and beaten during his visit there. My husband who came to America few years after me suffered a heart attack and died. I met my American husband about ten years ago, and we married soon after we met. My husband also teaches ballroom dancing. This is how we met. My American husband says that with me in our house, he feels he is in heaven. He likes Iranians for being so kind and hospitable. I tell him that if someday he could go to Iran he would enjoy the Iranian warm culture even more, but the regime makes it difficult to feel free there. I for one miss all the relatives and the warmth of friends and family, the language, and the comfort that comes with being in your own country. In America, women have a higher value than in Iran. American men have a lot more value for woman's legal rights and freedoms. In Iran women don't have the independence and freedom and values that women have here. Iranian women have to be domestic. The difference between Iranian men versus American men is as drastic as the difference between black and white. Iranian men are family oriented and are more responsible toward their first family like their parents, but American husbands are more committed to their wives first. When Iranian women come here, they do fight some of the cultural expectations that Iranian husbands have of them. I think this is why there is a high divorce rate among Iranians. Women know they have options here. During the shah, there were very few divorces. The cultural expectations didn't allow for the woman to leave even though their marriages had been arranged. Men were in charge of divorcing 
the women. If there was ever a case of a woman divorcing a man, she could not collect the mehriah (which is the amount of money or other valuables to be given to the woman in case of a divorce). If a man divorced a woman, he would find a way to get out of paying her the mehriah. So divorce was not a good option for women and women were tolerant of almost any situation to avoid being divorced. In America women have considerable legal rights even more than women did in Iran during the Shah. I noticed that during my previous visits to the U.S. Beyond just the hejab, in Iran you succumb to the patriarchal teachings in the culture and religion due to social pressures even if you are not religious. For example, during the Shah, we had parties with dancing and no hejab. Now the government doesn't allow for dance music at parties, but it's often the neighbors who report you."

5. Sharareh. "I came to this country in 2000 at the age of thirty-three through marriage to an Iranian man who had spent years here and was ready to start a family with a woman from his home country. I did not know him before I married him. My family was somewhat familiar with his family in town. The families liked each other and thought it appropriate and a safe choice. I did have the choice to say no, but I wanted to come to the U.S., and after getting to know him in a couple of weeks, I thought he would be ok. I had heard that women in the U.S. had so much freedom, especially in the absence of the hejab. Life would be comfortable in that you would work and live the way you want to. I was financially independent. I had received my baccalaureate in English and had two job offers, one as a teacher and the other in the post office. I chose to work in the post office where my father was a supervisor. Working as a teacher with 
young female students meant that you were expected to not only uphold a very strict version of the hejab that meant no makeup or showing of hair but your personal life was also scrutinized for proper Islamic behavior. Since teachers were considered role models for the young students, especially the girls, then you had to consider that at social gatherings, private parties, and on the street you would need to cover your hair well. No dancing, no makeup and no playing any western style music (anything about romantic love). At the post office, I would just have to adhere to the hejab at work and not be worried about anyone reporting my personal preferences at home and social gatherings. My family practiced Islam, but by no means were they fanatics or fundamentalists. They did pray, and my mom always covered her hair and was modest even before the Islamic revolution, but she never forced my sister and me to dress in any particular way. We were trusted and free to choose what we wanted to wear. I was only thirteen when the revolution happened. Even though it's customary to have young girls marry shortly after high school and most likely after college and there were plenty of relatives who kept asking me, when are you going to get married, my family never pressured me into marriage. I also have two older brothers who were not controlling me or my younger sister in telling us how to be more careful with our hejab or pray or any other religious practices. I went to college right after high school. There were two options for college. Either you could go to government schools that were practically free or you could go to private schools that were too expensive for the middle class families, such as mine. If a family had enough money for private school, they would often put their sons in school. On the other hand, the free government schools had so many applicants that many would 
be rejected. Furthermore preferences on accepting students were given to families of the victims of the Iran-Iraq war who got help with their tuition. In my state at that time, which is not as modern or populated as some other states in the country, there were only three fields offered at school to study, agriculture, which was reserved for boys only, nursing reserved for women only, and English and Farsi language which either sex could pursue. You would have to take a very difficult entrance exam and see in which field would you have the best score and according to your grade and availability of space in certain colleges, you would be positioned. Most of us female students were afraid that once we graduated from college, with so few jobs available, we would not find any work. If there were any work it would often be given to the men in the belief that men are the head of the families and are responsible for supporting them. I have visited Iran twice since I moved here, and I have noticed a remarkable change in that women are not as harassed for driving or being visible. There are more of them in colleges around country. They are getting married later and have fewer children, mostly just one child. More of them are financially independent because they went to school and secured somewhat of a job for themselves. Many of them don't want to marry at all maybe because they know how hard it is to get a divorce. I didn't marry til I was thirty three years old, and only when I was presented with the opportunity to come to the U.S. I would have gone to any other country too that didn't harass me over the hejab, even to India. In Iran it's very hard for women to control or change their legal and cultural restrictions. The government and people don't allow for it. I know they are always trying whether they're in the parliament fighting the laws or on the streets fighting the enforced hejab. When young 
women are pushing their scarf back to show their colored hair or when they wear makeup or tight clothing, they are defying the regime. The girls go on the street in groups so if they get harassed for their improper hejab, they could fight the guards easier as they argue back and make a scene to get the public support. Some families are supportive of their daughters fighting the hejab. For example, if a woman is detained and taken to jail overnight for not observing the proper rules of the hejab, then her family is phoned to come sign and guarantee that they would not let their daughter repeat this. It's also done to shame the family for not teaching their daughter better Muslim behavior. Some families' response is that their daughters are free to do what they want to do, and the government realizes that at times it doesn't have the support of the people in enforcing the unpopular hejab. I am now going to college and majoring in education so I can work with kids. I really like to teach and I think it's a lot easier to be a teacher here than in Iran where my personal life will not be monitored. My Iranian husband has lived in the U.S. for the past twenty years, but I think even if Iranian men live here for a hundred years they will never change their ways. They are controlling of their wives and the finances. This is not to say that Iranian women allow them. Iranian women in the U.S. show more control in their relationship since they see the freedoms and choices they have here." As an Iranian woman married to an Iranian man, she says that there have been no changes in her gender role within the family as the wife. She wishes her husband would help more with all the chores in their lives. She thinks Iranian men are very proud with big egos. They protect their families better than American men. She says, American 
women are very brave to fight for their rights and they seem to have an easier life than Iranian women.

6. Sara came to this country in 1996 through marriage to an Iranian man at the age of twenty. She does not remember the revolution since she was only three years old. She was from a middle class family. Her dad was an accountant and her mother a house wife with three kids. Sara has two brothers, and she says no one in her family was involved in the politics of the revolution. Sara says that even though women in Iran are increasing their freedoms gradually, the years before she came to the United States were so bad for women there that she thought her husband was bringing her to "heaven." "I went through a few rough years here as I suffered from isolation of not having my family here especially since I had a big family. It took me a while to learn the language which made things that much harder especially understanding the cultural differences. I can see that I was right about women in America having more freedom and rights." Sara thinks that Iranian men can be good providers and protective of their families but at the same time they expect too much domesticity from their wives. "Even though I work at the bank and contribute to our finances, I am expected to take care of our two children and do all the house chores. I think American men are easy going and are fair in treating their wives."

7. Faranoosh came here at the age of seventeen in 1988 with her only brother. She wanted to go to school here and her family had every intention of supporting her decision since they did not want either one of their children to live under the current regime. "In high school I was being harassed for occasionally showing some hair out of 
my scarf. My parents and I knew the harassment was going to continue yet the opportunities for a better life were not. The hejab gets in the way of your freedom. It's everywhere. As a woman, you are constantly being checked and searched. It's so degrading and ridiculous that you have to be preoccupied with whether your toes are showing hair or you are carrying makeup. Of course there is no freedom of press, just government propaganda. My family was not traditional by any means. They were, especially my dad, very nationalistic, not leftist or religious, just one of the believers in Mossadagh ideologies of democracy and was against the Shah. I studied electrical engineering, and I believe that if I were to go back to Iran I would not be given a job since those types of jobs are often given to men who are assumed to be the head of the household. This gives the guys more control over the women. Women there get educated, and when their school is finished, they are disappointed that they cannot get jobs. They are disappointed that maybe they should have invested in a marriage life and finding a husband. Having said that, women are having fewer children and getting married later or at times never. While most women there have a lot of pressure on them to be beautiful and to be supported by a man. If they are pretty and invest in their beauty, then they think they are entitled to a good life by having a man financially support them. The men in Iran are promiscuous. They can have the temporary marriage, which is like prostitution. They can have several wives, which they can not even financially support. Women have become prostitutes increasingly just to support themselves through the high cost of living. A childhood friend of mine who is in the acting profession says that even worse than Hollywood for a woman to make it through movies and acting opportunities, 
she has to provide sexual favors often. As it is, you don't see many women in the media freely expressing themselves and their grievances. Aside from being exempt from certain roles, they also have to adhere to the hejab which is even further limiting to their art of filmmaking. If they do discuss the problem of prostitution or poverty among women there, is not enough freedom to blame any of that on the government or religion, but they do blame the culture and society at times. This is all to the benefit of the men there so much so that even when they come to the U.S. they don't want to change. I am glad I came to the U.S. I have finished my education, and I can go to work without any harassment from anyone. Iranian men judge women simply based on appearances. They chase the prettier women and then try to control them. They do treat Iranian women worse than they would American women. They expect Iranian women to perform a lot of domestic chores and to be traditional in that the wife should not have a social life of her own without her husbands or go places without him. My own husband who came here twenty-six years ago at the age of fourteen has not changed his traditional expectations and is not any different from the men in Iran. Iranian men in America just pretend to be different because it's politically correct. I think American men give their wives a lot more freedom. They are not so controlling. They share in the housework and respect women as individuals not just as wives. There are more freedoms for women in America. As far as I can see women can do whatever they want here. Some Iranian men who don't care for the liberated Iranian women in America go to Iran and choose the youngest and prettiest girl as a wife and bring her here. These women often use the men to get to freedom and as soon as they become independent and either leave the husband 
or not tolerate their control. They are often materialistic, especially upon seeing all the consumer goods in America, and they overspend and put financial pressure on the men which further strains their relationship. The women come to the U.S. with high expectations of being provided for and don't want to work so they become dependent on the men and the men can not give them all they want so there are high divorce rates in these marriages."

8. Zahra says that although she came here just a year before the revolution at the age of fifteen as an exchange student and to pursue higher education, she decided to stay in the United States after she completed her education because of the changes that the revolution had brought to Iran. She learned about the loss and lack of many civil and legal rights especially for women in Iran. She did not come to stay. "I came here for education but stayed for political, religious, and social freedom." Her mother was illiterate and her father had only a sixth grade education, but she considers them “modern." Her parents were Muslims but were not practicing nor were they political, but she herself says that she was against the Shah. She is divorced with no children, and she is the coordinator of an Iranian women's group that organizes lectures on a variety of issues from art to women's rights. Also, it provides an online group for Iranian women to connect. On the status of women in Iran she says, "Unfortunately women have lost some of their basic, personal, social, civil and economical freedoms. For example, they have to follow Islamic dress code, they can't travel without their husband's permission, they have lost the right to divorce, and they have lost the right to become a judge." Zahra thinks that the number of women going to universities is higher than men. Since the culture 
expects men to be providers so the men often go to work and don't have the time for a college education. Zahra goes on to say that in Iran women's freedom of social and economic mobility has been limited legally. For example, it is very difficult for a single woman to rent an apartment for herself or get a hotel room. Zahra says, "Some of the jobs have been reserved for men only. For example, a woman cannot become the president. This is why some people call the presidential election in Iran illegitimate because half of the population can't participate in it. Even though the percentage of women with high education is larger than that of men, managerial work and higher-paid jobs are normally reserved for men. Prostitution among women has risen as a way to survive the high cost of living." On women's role in family and society, she says "there is much emphasis after the revolution on women's place being in the family and at home. So, the role of women in society is to be mothers and wives rather than independent and singles. Women's civil and legal rights have been altered heavily after the revolution. For example, they don't have the right of divorce, or the right of raising their children after divorce. In a court, two women's testimony equals one man's testimony. The inheritance for a man is twice as much for a woman." On hejab, Zahra says that "What one chooses to wear should be a freedom of self expression. The government should not force any dress code on people. I am totally against the hejab for myself and in public schools for girls. If adults choose to wear hejab, it is their decisions, but, I am against forcing girls to wear it before they reach adulthood. It is gender discrimination at a young age." On the role of women in the media Zahra says, "In Iran women have done a great job publishing newspapers and magazines such as Zanan to address women's 
issues. Unfortunately government keeps closing their offices and stopping their publications. Because of the important role the media plays in forming our perceptions, it is crucial for the women who believe in women's equal rights to influence the media to reflect their views. There is no law in the U.S. based on gender to prevent women' social and economic mobility. Thanks to women's liberation movement in the U.S., a woman can do and become anything she wants just like a man. However, (even in America) sometimes culture and media define women in a way that is limiting by portraying them as sexual objects or domestic." As far as the challenges of living in America, Zahra says that she has adopted the best of both cultures, and it is a "blessing." She doesn't feel any isolation and difficulty with the language. She says, however, after $9 / 11$ she has been searched more and questioned at the airport due to her nationality. As far as sexism, she says, "unfortunately it is worldwide but much less in the U.S. than some Middle Eastern countries that I have traveled to." On the question of whether Iranian women fight against patriarchy in Iran or here, she says both groups do challenge patriarchy in Iran and abroad. "Iranian women's activists who had to flee Iran because of their struggle for women's freedom against the government have continued their activity abroad. There are some women activists who believe their fight in Iran is more effective, so they continue their struggle in any form with all the hardships and risks, for example, Simin Behbahany, the dominant poet, or Nooshin Ahmadi Khorasany, a journalist, and many others. Iranian women abroad who care about women's issues are active in either Iranian woman's groups or in international or an American women's group." As far as her expectations of Iranian men here or in Iran, she says, "If they claim to be liberal or open- 
minded then they should change their cultural learning toward treating women. They should see them as equals and treat them as such in all aspects including sexuality. Unless Iranian men shed their sexist cultural learning, it doesn't matter where they live, in the U.S. or Iran. They end up treating women the same. Most American men and not all of them, who have been exposed to the changes of women's liberation movement, treat women as equals. This is especially obvious in sexuality. For example they are not expecting their date to be a virgin. My relationship with my partner who is not Iranian has been that of equal partnership rather than master and slave as it is often the case in Iranian marriages in Iran. My expectation of Iranian men is to grow up and back the Iranian women in their plight for freedom and equality. American and European men are more responsive to the needs of their wives while Iranian men are good in ordering their wives and daughters around. Western men believe in equality of sexes. At least they try, while Iranian men are spoiled, dictatorial and indifferent to the needs of their women. Patriarchy is alive and well in the Iranian community both here and in Iran especially with older generation. However, I believe the younger generation of Iranian men is more open to the needs of their women."

9. Mojghan had visited the United States in 1973 as a seventeen-year old exchange student during the Shah's regime when such programs were available. It was not until she was thirty-five in 1995 and came back to the United States on a visitor's visa that she applied for political asylum, which gave her the permanent residence status. She has lived here since. Mojghan says that she had been imprisoned for three years after the revolution for holding leftist beliefs. After she was freed, she was not able to establish a 
career as she was treated as a "second rate citizen" for having engaged in political activities against the regime. "I was not allowed to go back to the public university to finish my degree and had to take the entrance exam to a private university two years after I was released. Even though I finished my time in prison, I was only released with the condition that my father would give the deed of his house to the government for two years which turned into five and in that period he could not sell the house or borrow against it as he was in construction and often needed to do so. My father and my brotherin-law would be held accountable if I involved myself in any political activities after my release. Their passports were confiscated and they were not allowed to leave the country. When my brother-in-law had to leave the country for Europe as his job required of him, the government put my sister in jail for forty days even though she had two young boys. This imprisonment went on her record, and for years she had trouble landing a job, especially government work. It was so painful for me to see that I have troubled my family to such extent. In other words, having some limitations in America as an immigrant is still better than having legal limitations in Iran and social limitations there when you cannot get a job due to your background. Although I did not come to the U.S. with the intention to stay, I have been here since 1993 and have no intention of returning to Iran permanently even though I would love to be near my family who are all living in Iran. I make a modest living through translating. Although I originally came here to further my education and start a career, I now would have to say that I have definitely decided to live here for as long as I have due to the lack of political and social freedoms in Iran. From my experience of living with some American women, I think American 
women are more gender conscious and know how to utilize their freedoms. I think living on my own in America as I have survived in an open culture has enhanced my personality in that I have become more self sufficient and independent. I can be individualistic and now have individual rights. I am more accepted here in American society than in my own country. As a consequence of having an established career, my confidence has improved and I can feel as strong as my brothers and I feel equal to them. I am even trusted to make serious decisions in the lives of my nephews after the loss of their father, a role that would have naturally gone to the uncles. As far as my family background goes, my mother has a general desire for justice and equality, but my father was very hopeful in the revolution especially in the few years after the revolution." As for the rest of her family, she says that all her siblings were also leftist in the early years after the revolution but now consider themselves liberals who want justice and equality in society. "I too have moved to the center and consider myself a liberal. My family, I would say leaned more towards a liberal standing especially the way my parents gave us the freedom to hold whatever political beliefs we wanted. They refused to push us into any traditional way of life. For example, my sister who is now fifty-six years old has never been married and has not been pressured by my parents to do so. Another example of their supportive and liberal way is that they let me become an exchange student at the age of seventeen in 1975. Based on my experience, Iranian women are fighting tooth and nail for their rights even including women who believed in the revolution and were supportive of the regime in the early years. Once they lost trust and did not see the expected results, they began to work in a more cohesive effort with other women's 
groups from different ideological beliefs including those who are religious and have ties to the government. This isn't to say that they don't suffer from arrests and imprisonment. I think women's movements in the west have positively energized the Iranian women. To give an example about their persistent struggles to maintain some of their rights, I will share with you the challenges Iranian women went through to maintain their sports programs. After the revolution, the clerics tried to put an end to all women's sports and pressured women to give up their desire for competitive or professional sports. But Iranian women fought back and gained access to some sports that according to the government would not interfere with the hejab, such as archery. Much more would have to be done to gain full and equal access to all sports desired by the Iranian women. For a few months after the revolution, women had no place to exercise, due to the segregation policies of the government that women could not work out in the same gyms. Despite much pressure from the government for women to give up sports, women found a way to go around the new segregation measures and push the government to allocate a stadium to them named Taj, a modern new stadium that had catered to the royal family during the Shah. The name meant crown. When it became a place for women to exercise, the government changed the street address of the stadium to hejab, covered the pool, had two male guards stopping the entrance of any men into the stadium, and in front of a newly installed curtain in the entrance, a woman was hired to check the membership cards continuously. Women were allowed to participate in body building, light gymnastics, volleyball, basketball, handball, track and field, badminton, table tennis, swimming, and diving. Prior to the revolution women had participated and competed in all sports, and 
the 1974 Asian Olympics games were held in Tehran. Women have continued to participate and compete across country and form leagues where in 1999 they participated in the first international sports competition despite much resistance from the fundamentalist clerics. They have a long way to go in achieving some of their basic rights, and since the revolution, their freedoms have been threatened by the authorities of the regime. Women are out-numbering men in universities and I believe that in most big cities women have just as many opportunities to access universities as men. There are women in higher education of all fields. Education has a high value among Iranians. I assume there is access to all jobs for women in the big cities. I don't believe there are any laws that would enforce equal pay or penalize sexism in the workforce. I don't think the revolution has changed the gender roles in terms of family structure as the men are still expected to financially provide for their families and women are expected to take care of the domestic chores. Just before the revolution Iran was moving towards modernism when the revolution and religious fundamentalists put a halt to that. I tend to think that I would have had quite the same level of economic prosperity, had I not immigrated to the United States as far as the opportunities go. Back in Iran I was a successful home tutor, translator, seamstress, as well as working with women's sports administration, considering the many limitations placed on me by the government. I have experienced much freedom of expression in the U.S. that has positively impacted my sense of peace compared to my worrisome life in Iran. I give myself credit for my achievements that I have attained through hard work in the U.S., but the fact is that the personal freedom plus the opportunities here have helped me achieve my goals. The fact 
that I had been a political prisoner has not just lingered with its negative emotional and social impacts but has also taken away many financial opportunities for me in Iran. I was familiar with the American culture before I immigrated. Although I have not experienced much difficulty with the English language, the challenge has been to be away from my family. I haven't experienced much prejudice for being Iranian, and I think that is because I live in California which is more ethnically diverse."

10. Parvaneh came here through marriage to an Iranian man in the year 2000 at the age of twenty five. She says that although she was only about four years old when the revolution happened and the revolution in itself did not cause her decision to come to the United States for political reasons, she knew that women here had more freedom and opportunities. She is an Assyrian (a Christian minority group in Iran and several of the surrounding countries such as Iraq and Lebanon among others). She notices that the Islamic laws after the revolution have decreased women's legal and civil rights and have forced the hejab on all women regardless of their religious or secular beliefs. She says that although she thinks women are more educated than ever in Iran, they are less mobile and have fewer social freedoms. Even though there are jobs for women to enter the workforce in Iran, they are paid less than men. Women are expected to be obedient to their husbands. She says she has not improved her economic status compared to when she lived in Iran. She had a decent paying job there and she is working in the hospital now as a radiological technician, which pays well. She does say that she thinks women here definitely enjoy more rights and freedoms in compared to Iranian women in Iran. 
11. Afsaneh came to the United States long before the revolution in 1964 as she found the political and social constrains "unbearable." She says she was growing up in an Islamic country even before the regime change. She was financially independent as she worked for the Iranian National Oil Company (AIOC). "As a girl growing up in an Islamic country, I felt my future's potential as a woman would be limited. I did not want to follow in the footsteps of the women around me. I wanted a different life not possible in Tehran. I thought I could live my life as I pleased in America. While in Iran, I had to live my life for my parents, grandparents, neighbors, cousins, and everyone around. I could not understand why boys could do everything they wished and we as girls were constantly watched and were not able to participate in sports or social activities. I also did not care about having to live with my parents until I was married even though I was financially quite independent. I came to U.S. to study electrical engineering. However, I never had the desire to return to Iran. In 1975 while I was working for Hughes Aircraft company satellite division, I was hired by the government of Iran to go back and head their satellite department at the Iranian Telecommunication Corporation. On my going away luncheon at Hughes Aircraft Company one of my colleagues stated that he did not think I could tolerate being in Iran beyond eight weeks. I returned in seven. I always say the first best thing I ever did in my life so far is when I left Iran in 1964 and the second best thing when I left Iran in 1975. After seven weeks in Tehran I could foresee a bloody revolution in five years. The night I left I told my entire family to sell whatever they had and leave Iran. They never did and regretted it ever since. I was born to a middle class family. My father was a businessman and mother was a housewife. My mother was 
twenty years younger than my father. They had married when she was thirteen and he was thirty-three. My parents had only two daughters, my sister and I. My father and most of his family were not religious at all. However, he did follow some Shi'a religious rituals such as giving alms on Eid Fetr, sacrificing sheep, cooking and distributing sholezard (rice pudding). Our father was very much in favor of our education. He felt that as women we needed to have a profession so we could stand on our own two feet without any need for a male provider. That is why my sister went into medicine and I into engineering. The only religious education we received was what we were taught at school, mostly Islamic Sharia. Our family was very political, anti Shah. We considered ourselves a modern family. We believed in social and political freedom for all Iranian people. The 1979 revolution, I believe, took the modern Iranian women back by centuries and at the same time brought the traditional women out of their home prison and exposed them to modernity. Women lost all their rights under the Islamic republic and went back to their more than a century old status of a second-rate citizen in Iran. Many women lost their jobs and many professions were denied to women. Women also lost their right to social and economic mobility due to the Islamic laws which force a woman back to the dark corners of home and society." On the question of whether you or your family experience harassment, prejudice or punishment from the government? Afsaneh answers, "Yes we did. My sister was arrested and imprisoned for a while for her political activities at the University of Tehran. She committed suicide in objection to the present regime by burning herself. Under the Shah we had some social, economic and religious freedoms. However we had no political freedom and that is what caused the 
1979 revolution and finally the end of Pahlavi dynasty." On the issue of hejab she quotes her sister: "Hejab is not a woman dignity, it is a woman's slavery." On the question of the role of women in the media, she says, "They should be present and are capable of doing the same quality if not better work than men. In America, I was able to work, go to university, complete my education, and work as an engineer, program manager, and president of my company. "I believe I could have never achieved as much as I have in the U.S. if I had remained in Iran. The EEOC, or equal employment opportunities helped quite a bit following my graduation as an engineer. Almost every company had no place for female engineers. In early seventies women were supposed to go into software engineering only. I was the first female to graduate from Cal State Northridge in electrical engineering. I now am involved in the community politics, write editorials for the community paper, and volunteer for some organizations and town activity. However, I still miss being in Iran and yearn for one of those family gatherings in Tehran. After living in this country for almost forty-five years I have just about overcome all the challenges of language, culture, prejudice, and sexism. I also don't feel isolated since I have assimilated fully in the community I live in. I get involved in the community politics, write editorials for the community paper, and volunteer for some organizations and town activity. However, I still miss being in Iran and crave one of those family gatherings in Tehran."

12. Bita came here in 1974 at the age of fourteen before the revolution along with her brother and parents. "We came here because my family wanted a good education for both of their children: my brother and me. We never had any plans to go back. My 
father was Russian and my mother was Iranian. Although my mom was from a religious family, I think she was very modern in her approach as she wanted equal education for both her kids. She was a housewife. Women didn't have to contribute to the finance of the home and my father made all the financial decisions. He was a developer and my mom could spend quality time with us. My father was not a communist or religious. He was so open-minded and gave us so much freedom that when I was fourteen, he told me you can have a boyfriend if you want, just let him know. He gave me all the freedom that he gave my brother. I don't know if my family would have been able to be so liberal under the current regime. I treat my son with the same freedoms that my father gave me. I went to school here and studied business management without any conditions. I think after the revolution in Iran there were so many religious conditions to get into schools and connections and a different system of testing and the limited space for students just to get into college that I would have never been able to pass all their requirements. I wouldn't have been able to pursue the path that I have taken in the U.S. I think women here have all the freedoms to work and study whatever they want. They have equality, they have high positions but this is not the case in Iran as our friends and families tell us stories of hardship with the mandatory hejab. I spent the first few years of my stay in Washington DC, and even with the hostage crisis happening in Iran I did not experience any prejudice or isolation. There is so much freedom in this country that even as an Iranian my son is proud to announce our nationality despite the sour relations between the two countries. I am working in a bank and feel independent and confident about my position in my family and this community. I feel as I am an equal partner in my marriage 
and as a parent and I contribute that to my family values and the freedoms I have been able to enjoy in this country. I am glad I have not witnessed or experienced any of the complaints that women have in Iran and I can say openly that I am proud of my Iranian identity."

13. Azeen came to the United States in 1985 at the age of seventeen. "I was able to get a student visa from Turkey after spending three months in Germany first and another three months in Turkey. My parents came on visitors' visas with me. They had to go back after six months of helping me adjust to life and getting me settled with an Italian family here. When I was fourteen, the revolution had just taken place, but I was supportive of the Mogahadeen group not the new regime. It was a period where the environment was open for political activities. There were all kinds of political factions within the leftist group and within the Muslim groups. I was mostly interested in helping the poor and was involved in charitable activities. All of a sudden the new government began a harsh and violent attack on all opposition groups. It was a huge shock to us. There was no regard for the young people who mainly made up these groups out of their optimism and ideological beliefs that they were going to change the world and the time was now. Certainly that's what I thought. The revolution had overthrown the monarchy and it gave us the sense that anything was possible. My mother thought it was a good idea to spend the three months of summer in Tehran. I am from Shiraz, and she thought if I am not around my politically active friends for a while then I would stop my activities. After I came back to Shiraz I noticed my friends who I had worked with in the Mogahadeen were being arrested and jailed. A year went by when one of those friends 
asked me for a few dollars one day. I didn't hesitate to give her the thirty dollars I had in my wallet. She was two years older than me and she held a more official place in the Mogahadeen organization in terms of responsibilities. Shortly after this incident, a warrant for my arrest came to our house. I was questioned in my support for the Mogahadeen group. I explained that I had not have political activities in two years and whatever work I had done for the group was before May $30^{\text {th }}$ of 1981 when such activities were not banned yet by the government. They brought up the financial support I had shown to one of the group members. I defended myself against the guard who was constantly threatening me from behind a curtain with two holes cut out for his eyes. Without telling me what the charges were, he kept accusing me of not cooperating for not mentioning any other members' names and activities. I finally told him that if he is referring to the small change I had loaned a friend, I would be happy to confront that friend to explain that the money given to her was for her personal needs and not in support of the Mogahadeen. He told me that we would have to do this at her graveside since she had been sentenced to death at the age of eighteen. I had never been more frightened. I spent fifty days in jail with much fear knowing that this regime had no mercy on anyone. They had killed kids as young as fifteen. They were trying to establish their power overnight and went to extreme measures to achieve it. They would show frightened young people of different political sects that they had arrested on television. They were forced to express their regrets for having political activities against the new regime. I was under house arrest for one year and could not attend school to finish my last year in high school. During my arrest, I was not allowed any visitations. 
My parents didn't even know whether I was alive. It was during these fifty days that my parents decided to send me out of country. This was not possible for the first year after I got out since I had to show up at some government's office everyday and sign my name to show I am still in the country and not active in any political activity. They were holding our house as ransom. When the year was over we went to the German embassy to apply for visas for all three of us: my mother, farther and me. We were given our visas but I had to show up personally at the embassy to sign some papers. This meant I had to fly from Shiraz to Tehran on a domestic flight. The plane that I was on was hijacked by a man and a woman who happened to sit next to me. It landed in Iraq which at the time was at war with Iran. In Iraq the passengers were persuaded to get political asylum by the Iraqis so it would be a good international publicity for them. The Red Cross talked us out of it by saying that we would be put in a camp for years under uncomfortable conditions before this could even become a possibility. Meanwhile, the Iranian government only cared about its expensive plane that had fallen in the hands of the enemy. They kept demanding the return of the plane. After a week we returned to Iran, with the exception of one of the passengers who did apply for asylum status. The Iranian guards took us directly to Eveen which is a prison where the most serious political activists were taken. I was only seventeen and I was sure with my history and the fact that the hijacker was sitting next to me on the plane that I was going to be killed by the government. When I was released the next day, my parents took me and without saying goodbye to anyone got on a plane for Germany that same day leaving all their belongings behind. My mom only had one child. She was such a feminist. She thought women 
should focus on their careers and not just be mothers with lots of children. She made sure that my father put properties in her name, and although my father made a lot of money, my mom always kept working as a teacher. My mom let her only daughter be so far from her in the U.S. as she told me I want you to be yourself and live your life the way you want to and not be treated as you have been in Iran. I am definitely here for political and social freedom. I was able to go to school here. I became a dental hygienist. I married a wonderful Iranian man who treats me well and we have two beautiful daughters. I owe my teachings about women's rights to my mom and all her support and love for me as she taught me about self respect, humility, charity. With all her money she never made the less fortunate feel inferior and was very compassionate towards everyone. Even though her family was religious, she herself never observed the hejab till it became mandatory after the revolution. I have been able to have a peaceful life here and raise my two daughters with dignity."

14. Faranak. "I came when I was nineteen years old in 1990 through relative visa. The 1979 revolution changed everything for my family. We no longer could have a peaceful life in Iran. There was so much unrest and with the added pressures of the IranIraq war my family decided to leave for the U.S. permanently. We definitely came here for the political and religious freedoms. My dad had been a translator for the Shah as political figures visited Iran. This in itself was considered an affiliation with the Shah's regime. We experienced much harassment and prejudice by the government and people for being associated with the Shah's regime. Although my family was Muslim, we never practiced. We considered ourselves a more modern family. Women in Iran are so 
suppressed in terms of opportunities for advancement in education and work. Women here have so many freedoms that can not be compare with Iranian women. I am so glad that I immigrated to the U.S. I have been able to receive an education free of any government involvement or harassment. I received my B.S. in psychology. I had some experience in Persian dancing in Iran, and after I finished school I decided to pursue teaching Iranian dance to young Iranian girls. It has become my career with several locations around the Bay Area. I believe in what I am doing in that it preserves our tradition. It helps the Iranian community come together to celebrate along with their children. It helps the children to be proud of their heritage and be encouraged to learn our dances. The kids see a large support among their own ethnic group where connections are made between people and organizations such as Farsi language schools and charitable organizations. I enjoy what I am doing since I get to express my passion and have a successful career. This career would not have been possible in Iran since it is forbidden for women to dance, especially in public. I have gained independence and respect here. In America I have had the opportunity to work hard in what I love to do. I have not felt any isolation, prejudice or sexism. I learned the language quickly and adapted to the culture easily. I especially have had the support of my Iranian community. I do wish Iranian men would show more respect towards women here or in Iran. I married an Iranian man and we have three children."

15. Sima. "I came here in 2009 through marriage to an Iranian man who is sixteen years older than me. I remember he told my family that he doesn't have a lot of money or a college degree. He was just a sales person for an insurance company with a modest 
income. He seemed like an honest and decent person. I wanted to come to the U.S., and I trusted him to be good to me. We were married shortly after his visit and I came to the U.S. within a year. His financial status was worse than I thought, and it continued to get worse as he left one insurance company for another. I am very disappointed. I started working at a preschool to help with the finances. I had to take a few child psychology classes. I have one daughter and I am sure we are not going to have any more children considering our finances. After I became a citizen, I applied to bring my mother and father here and had plans to apply through them for my brother and sister who are younger than me and have always wanted to come to the U.S. I didn't want to live in Iran any longer either. I was often being harassed for not upholding the hejab properly. Once I was detained and taken to jail overnight for not observing the proper form of the hejab on the street. My family was phoned to come and sign a guarantee that they would not let their daughter do this again. They tried to shame my family for not teaching me to be a better Muslim. My dad told them that his daughter had the freedom to do what she wanted. The guard realized that this time he didn't have the support of the family to force the unpopular hejab. They let me go after a few hours, but I was tired of the harassment. I got my B.A. in the English language in Iran. As one of our requirements in college we had to take classes on Islam. My teacher who was a cleric would constantly solicit the girls in the class to sleep with him for passing grades. Women were often perceived as sex objects or mothers. My family was modern in their expectations. My mother, a housewife, never pressured me into marriage. My brothers never said I could not have a boyfriend. My father taught Farsi literature. Although they prayed and 
were Muslims, they never asked us to practice Islam. They didn't like how the regime was using Islam to suppress freedom. They all want to come and live here with all their children, and we are working slowly through relative visas to make this possible. I am aware and enjoy the freedoms in this country. Even though financially it is going to be very difficult for me to bring my family here and support them till they can be on their own, it is something I am committed to do. As one of the best features of America life, aside from not having to uphold the hejab, one doesn't have to wear expensive clothes or jewelry at gatherings. You can just wear a pair of jeans when you want to go out of the house and don't have to worry about impressing anyone or being judged based on your appearance. As a girl in Iran you had to be pretty and try to stay young. I knew many young women who had plastic surgery. It was funny because some didn't need any work done but would wear a bandage across their nose to suggest that they did have the money to have plastic surgery." 


\section{Appendix B:}

\section{Interview Questions}

1. What was the process of your immigration to the U.S.? When did you come?

How old were you?

How did you come? Visa, asylum or through family?

2. Why did you come to the U.S.?

How did the 1979 revolution impact your decision to come and/or to stay?

Did you come in search of political, religious and social freedom or to improve your education and economic status?

Did you come to stay?

3. Provide a brief background of you and your family's history in Iran.

Education

Employment

Religious affiliation and level of observance

Marital status, children

Political views

Family's culture: traditional or modern

4. What is the status of women post 1979 revolution?

Women's education

Women's freedom of social and economic mobility

Women's access to employment and type of pay

Women's role in family and society

Women's civil and legal rights

5. Did you or your family experience any harassment, prejudice or punishment from the government, associates or relatives for any of the above affiliations in Iran?

6. What do you think of the Hejab for you and others?

7. What do you think of the role of women in the media?

8. How do you compare the status of women in the U.S. to that of Iran on the above criteria? 
9. Prior to coming to the U.S. what were your expectations or aspirations of an American life as a woman?

10. How have you improved your personal and/or professional life here? Does this involve changes in gender roles or patriarchy in the family?

11. What positive opportunities have you become aware of post migration and how have you taken advantage of them?

12. What are some of the challenges of living here?

Language

Culture

Isolation

Prejudice

Sexism

13. What expectations do you have of Iranian men here or in Iran?

14. How are Iranian men different here than in Iran or versus American men?

15. Do you think Iranian women are fighting various forms of patriarchy here or in Iran? Explain! 